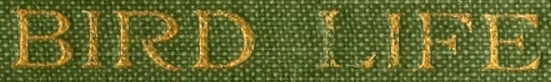

IIV. Y. T. D V.AT.ES

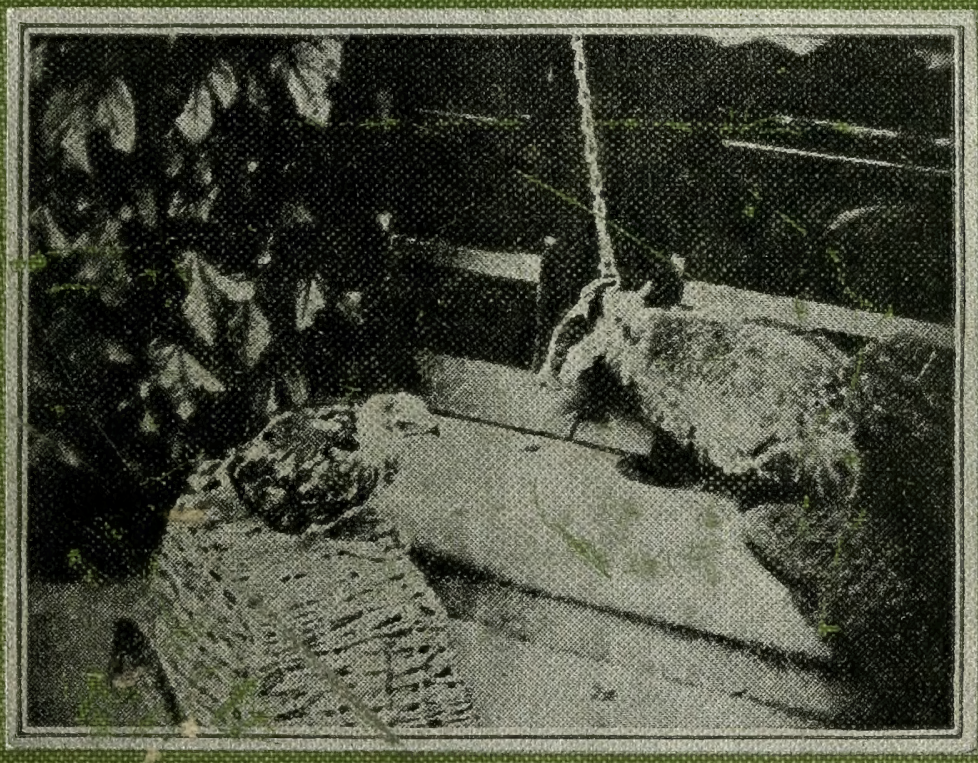

(3)

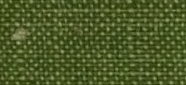

$Y(x) 17 \times$

W( 
157 


$$
\begin{gathered}
\text { HWW ooluma } \\
\text { cop.no }
\end{gathered}
$$







\section{BIRD LIFE IN WILD WALES}


For all Lovers of Natural History. The "Brightwen" Series. * * *

Illustrated. Crown 8vo, Cloth, 2 s.

I. Wild Nature won by Kindness.

More about Wild Nature.

Inmates of my House and Garden.

4. Glimpses into Plant Life: An Easy Guide to the Study of Botany.

$$
\text { By Mrs. BRIGHTWEN. }
$$

5. In Birdland with Field-Glass and Camera. By OLIVER G. PIKE.

LONDON: T. FISHER UNWIN. 



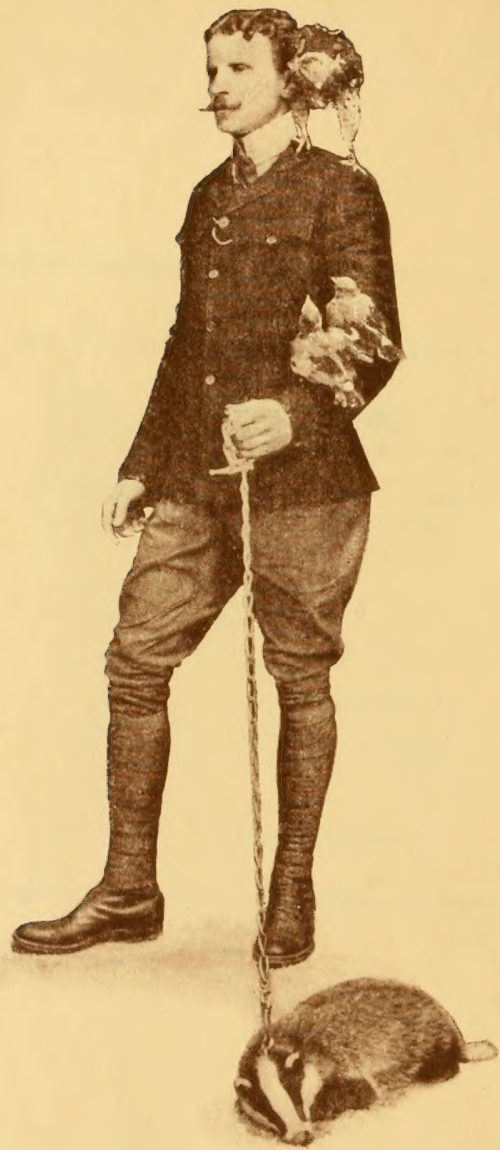

THE AUTHOK WITH HIS FOUNG BLZZARD, BADGER AND JAYS.

Photo by P. B. Alery, Builth Wells and Brecon. 


\title{
BIRD LIFE IN
} WILD WALES

\author{
J. $^{h^{n}}$ A. WALPOLE-BOND \\ AUTHOR OF "THE BIRDS OF BROMLEY \\ (KENT) AND ITS NEIGHBOURHOOD"
}

ILLUSTRATED WITH PHOTOGRAPHS BY OLIVER G. PIKE, AUTHOR OF "IN BIRDLAND WITH FIELD-GLASS AND CAMERA," ETC, ETC.

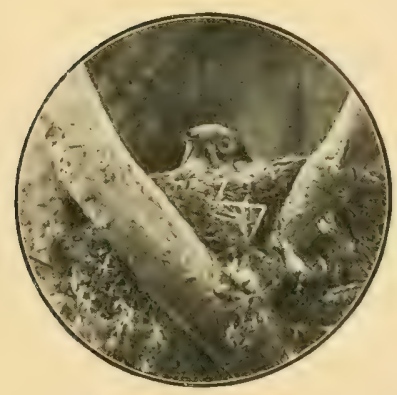

LONDON: T. FISHER UNWIN PATERNOSTER SQUARE • I9O3 


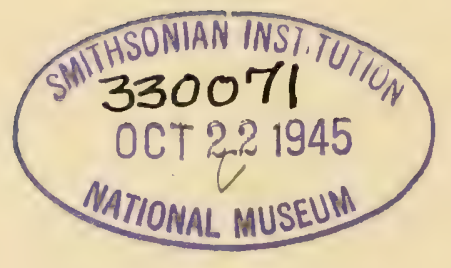

(All rights reserved.) 
. W 21

\section{Dedication.}

THIS BOOK

I AFFECTIONATELY DEDICATE TO

COLONEL EVAN AUBREY THOMAS,

LATE OF THE 7 TH DRAGOON GUARDS

("THE BLACK HORSE"), AS

A SMALL BUT CORDIAL

TOKEN OF ESTEEM. 



\section{PREFACE}

THE ensuing pages are not meant to be a scientific or comprehensive work on British Birds, but simply records of observations and sketches made in the course of many rambles amid their haunts.

It will be seen that our lines have fallen in fair ground with regard to some of our rarer speciesnotably the Kite, now almost extinct, the Buzzard and Raven, which are both rapidly becoming so, the Crested Grebe, Pied Flycatcher, and others. For such advantageous opportunities we are decply indebted to that ardent and excellent naturalist and sportsman, Colonel Evan Thomas, as well as to his brother, Mr. E. D. Thomas, and his nephew, Mr. A. Thomas.

To another excellent brother-naturalist, Mr. J. Williams-Vaughan, we also owe our obligations, nor shall we readily forget his great kindness in allowing us the run of his house, whilst he himself was away, in order that we might follow up our studies. 
Many thanks also are due to his cousin, Mr. A. Gwynne-Vaughan, another good all-round sportsman, as well as to Rev. D. E. Owen for much valuable information and help; also to Mr. P. S. Phillips, Captain G. C. Beauchamp, Captain C. H. Wood, Mr. R. Gilbert, and the following keepers, W. Watkins, Enoch Thomas, and W. Webb.

Mr. Pike, who is associated in this work, is already known to the bird-loving public, and he has spared no pains in getting the best possible photographs. At his own request, I may add that, except on a very mild scale, he is not an egg-collector, and may with safety be shown the haunts of our rarer birds. I personally took him to the nest-haunt of the Kite, Buzzard, and Raven, as well as other good things; but I feel confident that he will in no way abuse the trust reposed in him, he having promised to keep the localities a dead secret.

I am much pleased with the two photographs taken by Mr. P. B. Abery, the Builth photographer, and they do him much credit.

We shall always be glad to hear from bird-lovers, and hope that they will report to us the occurrence of any rare bird which they may be fortunate enough to observe.

J. A. WALPOLE BOND.

The Bungalow, Tyn-y-Graig, NEAR BUILTh, BRECONSHIRE

July, 1903. 


\section{CONTENTS}

CHAPTEK

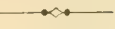

1. A WEEK IN THE HILLS

PAGE

II. SOME WELL-KNOWN FEATHERED OUTLAWS .

III. WITH THE RAVENS IN WALES * * 39

IV. SOMF, BIRDS OF THE STREAM - • 55

V. A SUMMER WITH THE BIRDS IN WALES, I9O2. 79

V1. WITH THE SEA BIRDS AT TENBY . $\quad 22$ I

VII. SOME RARE BIRDS IN THE PRINCIPALITY - 232

VIII. SOME ROUGH NOTES . . . 240

IX. WITH THE PFREGRINF AND MERLIN IN BRECONSHIRE . . . . . 249

X. IN THE NEST HAUNT OF THE KITE (MILVUS REGALIS) I9O3 • . . $\quad 259$

XI. OBSERVATIONS ON BIRDS . . 280 



\section{LIST OF ILLLSTRATIONS}

AUTHOR AND HIS PETS . . . . . Frontisfice

PAGE

I. “THE KEEPER : A STURDY, BRONZED, BEIVHISKERED FELI.OW" . . . . . . . . 3

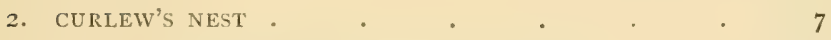

3. RING OUZEL'S NEST WITH EGgS AND YOUNG • • I3

4. SPARROW-HAWK'S NEST • . . . 2 I

5. KESTREL'S EGGS IN VERY ANCIENT NEST OF MAGPIE - 25

6. CARRION CROW'S NEST . . . . . . 33

7. A ROOKERY . . . . . . . 37

S. A WELSH WATERFALL: IN THE RAVEN'S HAUNT · 43

9. RAVEN'S NEST . . . . . . . 47

IO. "FACILIS DESCENSUS AVERNo" . . 5 I

II. RAVEN'S NEST WITH TWO EgGS • • • 53

I2. DIPPER'S NEST - $\quad$ - $\quad$ - $\quad$ - $\quad 57$

I3. GREY WAGTAIL'S NEST . . . . 59

I4. NEST OF YELLOW WAGTAIL . . . . 6I

15. SANDPIPER'S NEST ON RAILWAY EMBANKMENT • • 65

I6. HERON'S NEST . . . . . . 68 
I7. KINGFISHER .

PAGE:

I8. REEI BUNTING'S NEST . . . . . 73

I9. MOORHEN'S NEST . . . . . . 76

20. SEDGE WARBLER'S NEST . . . . . 77

21. REED WARBLER'S NEST . . . 81

22. BALGER'S "SET" . . . . . . . 85

23. HAIVFINCH'S NEST . . . . . 92

24. ROBIN'S NEST . $\quad$. $\quad$. 95

25. PHEASANT'S NEST . . . . . . . 99

26. WOODLARK'S NEST . . . . . 105

27. LESSER SPOTTED WOODPECKER'S NEST-HOLE - . III

28. PEEWIT'S NEST • . . . . . . 125

29. NEST OF RED GROUSE . . . . . I29

3O. STONECIAT'S NEST . . . . .

31. WOOD WREN'S NEST . . . . . . I45

32. CHIFF-CHAFF'S NEST . . . . . $\quad$ I49

33. NEST OF MISSEI-THRUSH . . . . . I53

34. StVAllow's NEST . . . . . . 155

35. SPARROW-HAWK'S NEST . . . . . 157

36. COOT'S NEST . . . . . . . 163

37. MEADOW PIPIT'S NEST . . . . . 167

38. EXTERIOK OF REED WARBIER'S NEST • . I7I

39. NEST OF GREAT CRESTED GREBE, UNCOVERED • . I75

40. NEST OF LONG-TAILEI) TIT . . . . I79

4I. TREE PII'IT'S NEST . . . . . . I83

42. NEST OF GREAT CRESTED GREBE, COVERED • - I 87

43. NEST OF WHITETHROAT . . . . I9O

44. BULLFINCH'S NEST . . . . . I9I 


\section{LIST OF ILLUSTRATIONS}

45. GREAT TIT'S NES'T I'11,

46. GOLDFINCH'S NEST . . . . . . . . . 199

47. YELLOW BUNTING'S NEST . . . . . . . 203

48. CUCKOO'S EGG IN GREFNFINCH'S NEST . . 207

49. SKYLARK'S NEST . . . . 210

50. A "SITTING" NIGHTJAK . . . . 2I3

5I. LESSER BLACK-BACK GULI. . . . . 224

52. CORMORANTS AND GULIS . . . 225

53. PUFFINS . . . . . . . . 226

54. YOUNG CORMORANT IN NEST: GUILLEMOT'S EGG BELOW 229

55. BUZZARD'S EYRIE . . . . . . 235

56. PIED FLYCATCHER'S NEST IN A BOX . . 243

57. MERLIN'S EGGS IN CROW'S OLD NEST • • • 257

58. OLD NEST OF KITE. . . . . . . . 264

59. KITE'S NEST OCCUPIED IN I9O3 . . . 273 



\section{Bird Life in Wild Wales}

\section{CHAPTER I}

\section{A WEEK IN THE HILLS}

WHAT hills? the reader may ask. The hills in question are-no, never mind where they are, as nowadays the greed of collectors and dealers is so great that any confidence is seldom treated as it should be. Therefore let us be content to say that they are somewhere in the Principality.

Here, then, let us take a glimpse of one of our rarer birds of prey, a bird well-nigh exterminated by a set of men who style themselves sportsmen, and by their sanguinary tool the gamekeeper, viz., the Common Buzzard. He is so-called to distinguish him from the Rough-Legged and Honey Buzzards, both rarities, especially the latter; though, as a matter of fact, "common" is a distinct misnomer, as Buteo vulgaris is the very reverse of that, at all events in our islands.

Come with us, then, to a charming little Welsh inn, nestling mid grim-looking hills and within a 
stone's throw of a bubbling mountain torrent, where we arrived one glorious evening at the very end of fickle April, after a five-mile drive or so through a magnificent range of cliff scenery.

Here, after a welcome cup of tea, we meet the keeper, a sturdy, bronzed, bewhiskered fellow; probably, too, as hard as nails, and we cannot help wondering if he will walk us down, as we start up a somewhat steep and slippery incline. At last the summit is reached. Here, two thousand feet above sea-level, one can enjoy range after range of unbroken hill scenery till everything fades in the blue horizon, the little white inn the while lying peacefully at the foot of the hillside which we have just mounted. Once on the top, too, stretched full length in the brown, sweet-smelling heather, there is ample time for a pipe, while we are ever watchful for any sign of bird life. Meadow Pipits flit about on all sides; Skylarks serenade us joyously, some entirely lost to view; whilst a shy Wheatear flits from a boulder of rock on to a slight eminence of the ground, looking anxious enough as he surveys us with critical eye. Somewhere near, no doubt, under a slate or pile of stones, he has his snug home, which may contain as many as half a dozen beautiful pale blue eggs. But we will not trouble ourselves about them: higher game is in prospect. And see, what is that? Sweeping round the edge of the hill, his strong. pinions cleaving the air, is a Buzzard-probably a male. Doubtless he has seen us, but that troubles him little, for here this splendid hawk enjoys protection, and long may he do so! 


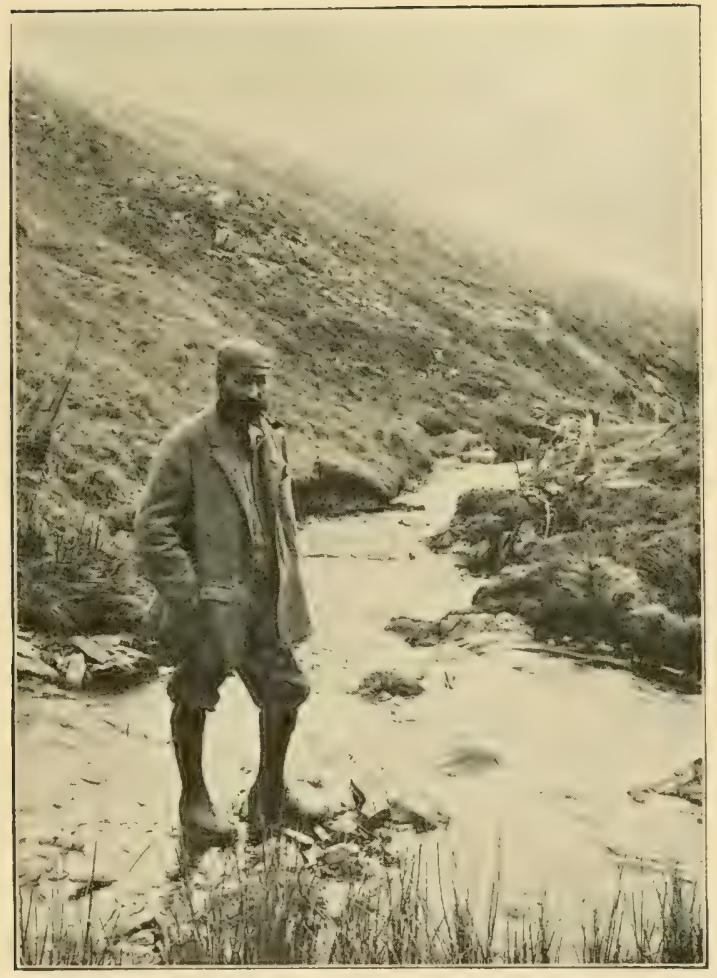

"THE KEEPER; A STURDY, BRONZED, BE-IVHISKEREI) FELLOWW" 

This bird may have its eyrie somewhere close at hand, and so, desiring a closer acquaintance with his domestic arrangements, we plod on over the neverending moor, disturbing as we go a pair of Red Grouse, which tell us to "gobac-bac-bac" plainly as any human being. Further on, the plaintive and trilling "curlee" of the Curlew is wafted pleasantly to our ears by the soft spring breezes; no doubt the ever-ivatchful male's signal to his long-billed partner, who probably is incubating her four large eggs at no great distance from us. No time now, though, to search for their nest, as twilight is already upon us, and if we would see Buteo in his haunt this night, we must hasten our steps.

We now approach a line of rocks, not very precipitous certainly, but still not an unlikely spot for an eyrie. Some way off, in a moderately tall mountainash growing from the hillside, a nest is visible, a Carrion Crow's for certain. There, too, on nearer approach, is the black rascal on her eggs; and she, seeing that we are gunless, remains brooding within easy range.

The keeper is not pleased at the sight, and is delighted when we tell him that we will loot the nest. We should here mention that in this neighbourhood this species is not preserved, and though we have a lingering affection for this bold freebooter, yet unquestionably he does a deal of harm at times, especially in the lambing season.

But here we are under the nest, which is a bare five-and-thirty fect up; and the first bough gained, all is plain sailing. Mind that decaying branch! so 
the nest is reached. Six eggs (rather pale varieties) repose in the smooth, wool-lined cradle, and they appear to be highly incubated. Shall the nest come down, too? No, let it stop; 'twill make a cosy enough home for some vagrant Kestrel this or next year:

We now skirt the rocks and come in sight of a small fir nursery, which scarce merits the name of plantation. Here, though quite a quarter of a mile distant, a huge nest is visible, which the keeper tells us is a last year's Crow's domain. We think otherwise, however, and the words are hardly spoken when the great Hawk we are in search of glides out of the lonely firs, making straight for the opposite crags, where we can see her plainly through our glasses at rest on a boulder, for it proves to be the female.

Thus far all is silent as the grave, save for the rush of a turbulent hill-stream close by; but as we near the clump the huge bird leaves her watch-tower and floats in spiral curves above us, where she is soon joined by her mate, easily recognised by his smaller size, both uttering their plaintive mewing cry, which harmonises so well with all the surroundings. Yes, the nest is here right enough; and what a place for a Buzzard's eyrie! Scarce twenty-five feet from the ground, it is built on the flat, horizontal branch of a Scotch fir, at some distance from the trunk, the deserted Crow's nest forming a groundwork for it, on which a fresh nest has been made, composed of sticks of varying lengths (many with the live shoots still on), and lined sparingly with Lusula syliatica (mountain grass). In addition, much down from the 


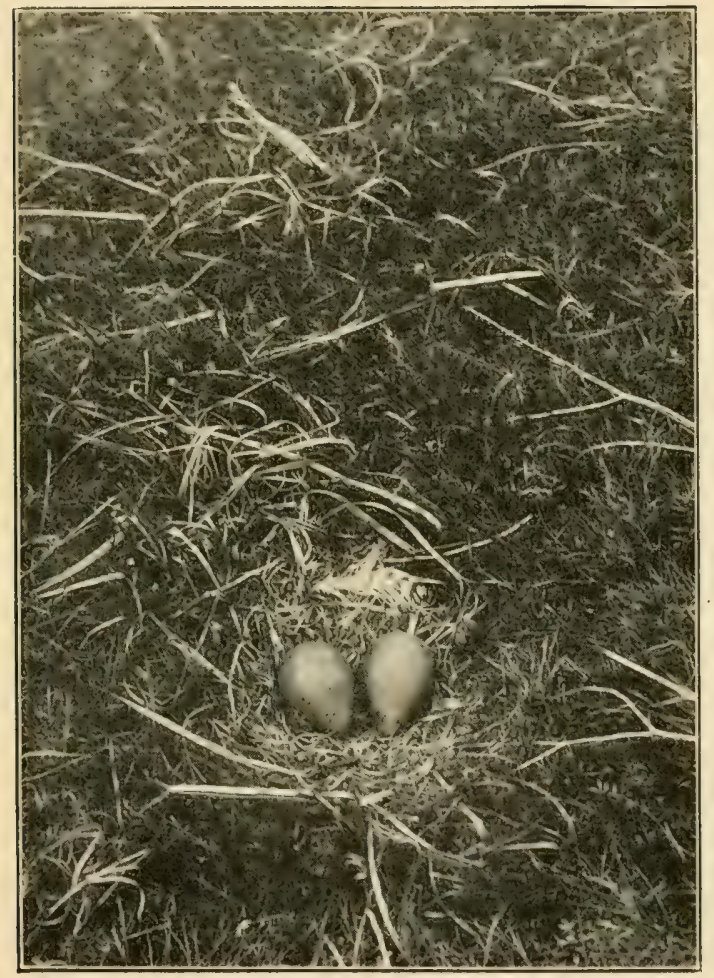

CURLEW'S NEST.

June 5, 1902. Wales. 



\section{A WEEK IN THE HILLS}

parent birds clings to the nest and the adjacent branches. The nest is very flat, and of the two eggs one is almost spotless, the other mottled all over with streaks of rust colour and lilac-grey.

The Buzzards still wheel above us in ever-widening circles, the female always the nearer; their cries wakening the echoes of the gorge below. But now the light fails us, and so we leave, wending our way homewards in the gloaming; nothing, save the incessant piping of the Summer Snipe, breaking the almost oppressive stillness.

At last our goal is reached, where hill mutton fit for the gods, with delicious home-made bread and prime ale, await us, to which ample justice is done; and then, after the fragrant weed, to bed, to dream of the Buzzard in his haunt, and full of ideas for the morrow, which dawns as fair a May Day as one could desire. Breakfast over by 7.30 , we are on the tramp again, starting for what proves to be rather a long day.

Now follow with us the course of this typical hillstream, teeming with small brown trout; for here they seldom run very large, though the keeper tells us of at least one monster. A Dipper dashes up stream, piping as he flies. How beautifully he takes the undulating course of the river! generally keeping to it, but every now and then making a ditour across some tussocky plateau, where the stream almost describes a semicircle.

Higher up, close to a most enchanting-looking fall, we drop across his nest, which, built in a rockformed angle, looks nothing more than a mass of 
decaying, slimy moss. If you would take a nearer inspection of his dank, foam-flecked home, get cautiously on to yon boulder-go carefully, for the rocks are treacherous, and a fall here means a drop into the darkling waters of a pool near forty feet deep. At last we are above the nest, still well out of reach, however. Down on your stomach if you would reach it; lean cautiously over the slippery rock which here slopes at a forbidding angle towards the sullen depths below; with the left hand grasp that clump of ferns, and now our right is within a few inches of the nest, when "swish!" off goes the hen bird. Here, inside the mossy structure, on a further nest composed of mountain grass and lined copiously with dead leaves, chiefly birch, lie the four spotless white eggs; so possibly she has not finished her clutch, or this species perhaps broods over its eggs, before the set is completed, as is the case notoriously with the Jay and Bullfinch.

A little higher up we light on the haunt of the beautiful Grey Wagtail. How charming the male looks, as midstream he sits on some boulder, the black patch on his throat contrasting admirably with his chrome-coloured breast and underparts! But see, with a warning "chiz-zit" he is off, probably to apprise his more soberly clad but equally graceful mate of our approach. Here, where the rocks almost mect over the stream, the leeper tells us is a favourite nesting haunt of theirs; and there is last year's nest, or we are much mistaken-a simple little structure enough, built on a jutting ledge of lichen-bespangled rock behind a sheltering tuft of herbage, composed 


\section{A WEEK IN THE HILLS}

principally of mountain grass, lined plentifully with fur and horsehair.

Still keeping to the river, with the Sandpipers for company, we reach a spot where the Buzzards have bred time out of mind. Both hawks are on view this morning but show no great degree of anxiety as we approach their eyrie, which, built on a large slab of rock jutting from the hillside, is by no means difficult of access. There are no eggs here as yet, and the birds keep at a respectful distance, now on almost motionless wing, now toying round one another, uttering cries of defiance at our intrusion.

Their broad tails are spread out fan-like, acting as a rudder in those giddy heights, and the sun at one time glints on their silver-barred underparts, at another on the rich brown of their backs and scapulars as they describe a half-turn. How enormous they look, too!-and indeed the Buzzard is no mean size, being about two feet in length and four across the wings. In the air it bears a striking resemblance to an eagle in miniature, more especially at a distance. Here their food consists mainly of carrion, such as dead sheep, which at times they find in plenty, but beetles of all kinds and rabbits come by no means amiss to them; but who will grudge them a leveret or rabbit, or even a sickly grouse? From their carrion-feeding propensities, then, it must be clear to every one what useful birds they are, and yet in most localities they are ruthlessly shot down and trapped. Unfortunately they are easy birds to trap, liking nothing better than to sit on some recognised bough or crag for hours together, of which habit the 
trapper takes advantage and seldom fails to bring poor Buteo to bag.

But we digress. Leaving this ancestral haunt of the Buzzard, we strike across the moorland, hoping, but in vain, for a glimpse of the Short-eared Owl, which, from what we can learn, breeds here sparingly.

Passing from the heathery waste, we once more reach a mountain torrent, which here runs between two magnificent lines of cliff, towering in places to perhaps eight hundred feet or more above the rough path which shirts the stream. In some places these rocks rise sheer or nearly so, whilst in others they are broken up into crags and fairly accessible turfcovered slopes.

Here on this beetling crag, then, three-parts of the way up the cliff, let us rest awhile and enjoy the beauties of a May afternoon. A colony of Jackdaws are tenants here for the season; they, noisy, chattering fellows, fly backwards and forwards past the face of the cliff, showing their displeasure in their cries. One, bolder than the rest, attempts to visit its nest, built a few feet above us, in a cleft of the rock, but seeing us so close, dashes off again.

Here, too, the pretty little "Red Hawk," as the Welsh call him - the Kestrel we mean-has his abode. Two or three pairs are in the air together at this moment, and what an embodiment of srace they look as, circling round one another on motionless pinions or stooping at some impudent Daw, they at length sweep into the rugsed hillside with their wild "klee, klee, klee, keelie," where in a week or so, on no more than a ledge of the rock, the handsome red eggs will 


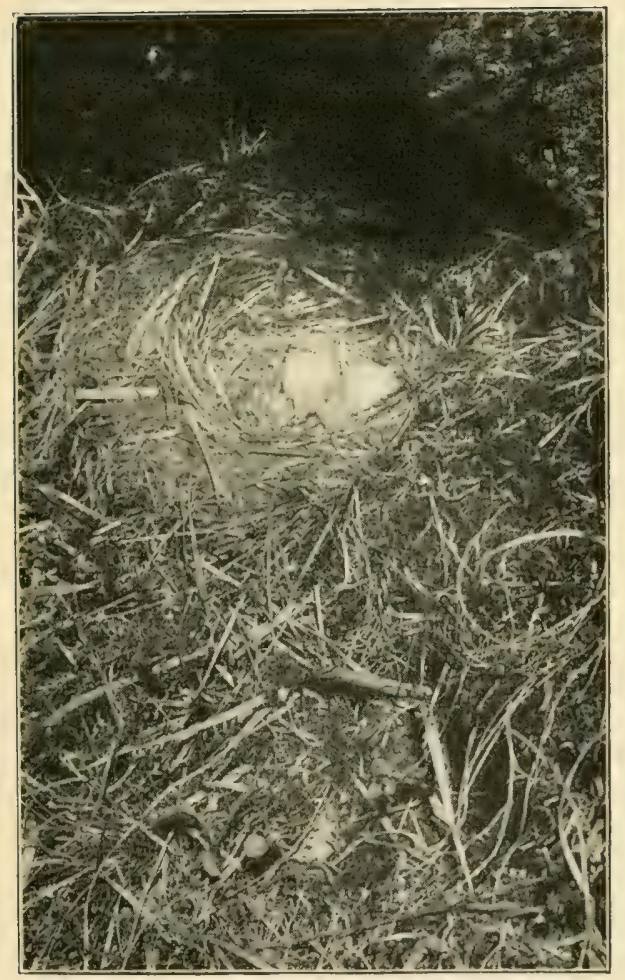

RING OUZEL'S NEST W'ITH EGGS AND YOUNG. June 2, 1902. Wales. 

be laid. Indeed, we examine several fresh scratchings during the afternoon, but none contain eggs.

However, 'tis time to be moving, so we wend our way as best we can along the treacherous cliffside, now bathed in the fading glory of the afternoon sun, enlivened by the cheery and wild song of the Ring Ouzel as he sits on yonder stunted mountain-ash, inviting inspection as it were. Close at hand we find his mate, who has already begun to "set" on her four eggs, so strangely like those of the Blackbird in general colouring, though perhaps a trifle brighter. The nest, too, is almost a facsimile of the last-named species, but the white gorget on the Ring Ouzel's breast is sure proof enough, and this is very conspicuous as both cock and hen bird dash wildly past us, uttering their "tac-tac-tac" of alarm as we inspect their brown-spotted treasures.

Further on still we find a Raven's nest, accessible only from above, which has unfortunately been robbed by some fellow or other when it contains eggs (the keeper knew of it when it contained three), and we fear that the birds will not attempt to rear a brood this season-though we see a Raven pass over the glen at a great height, a sepulchral croak first giving us intimation of his approach.

Before leaving these charming Welsh hills let us visit one more Buzzard's eyrie, this time containing eggs highly incubated.

Here in a rugged gorge is the nest, built far up the cliffside, behind a friendly furze-bush, and similar in all respects to the one first described in these pages, only lined with tufts of mountain grass instead of the 
blades. There are three eggs, real beauties. One in particular calls for our admiration, being splashed and mottled with rich rusty red on a bluish white ground. Another is marked heavily at the smaller end.

When we first see these Buzzards they are waging war with a pair of Carrion Crows, which have evidently approached their sanctuary too closely, probably with an eye to the huge eggs lying so temptingly exposed on the steep hillside.

The two Buzzards are now thoroughly aroused, and having driven off the Crows, turn their attention to us, the female actually coming within a few yards. The great talons are easily visible as with straightened legs she prepares to stoop at us, but abandoning this idea, contents herself by swooping round above us within easy gunshot, mewing the while. This Hawk's cry is best rendered, we think, by a prolonged and plaintive "seiou," uttered chiefly during the season of reproduction. Here now let us leave them in their mountain fastness with a sincere hope that many broods of Buzzards will swell the feathered throng for years to come. Here may their wild scream resound year by year in the solitary flyfisher's ear, and may he be sportsman enough to realise how desirable it is that so useful but so fast a decreasing species should be preserved with all the rigour of the law.

With a fleeting glimpse of a Raven's nest containing young we must finish. Fortunately we find that the young have not flown (though it is now May 5th) and often enough they are fledged ere this, for Ravens are one of the first birds to go to nest.

This nest is in a steep little dingle running at 
right angles to a stream, with sides perhaps two hundred feet high, the first hundred and fifty feet a very steep incline, the remaining fifty falling sheer, and in places curving inwards to the crags beneath, where a mountain torrent foams. In this last part of the cliff, under an overhanging boulder of rock, is the nest, a huge pile of sticks lined copiously with heather, wool, hair, and other soft substances, while the whole of the cliffside underneath is frecly whitewashed by the three young Ravens, marking the site of the eyrie at some distance. From the opposite side of the dingle we can get within twenty feet or so of the nest and look down into the gaping red mouths of the trio. The hen bird meanwhile, up above, is croaking forth her displeasure in no soft language, tearing off the twigs and smaller branches of the mountain-ashes hard by. The cock does not put in an appearance: doubtless he is off foraging on more distant grounds.

Anxious for a nearer view, we skirt the gorge, and reach the side containing the nest. Every step the cliff gets steeper, but steady does it: mind that apparently firm-looking piece of slate, which if trusted to will land us on the sharp and cruel crags beneath; cling to any tuft of heather to hand, and now see, this grassy and slippery path, let into the cliff at a breakneck angle, will lead us to within a few feet of the nest. Down we go, inch by inch; here a snag of rock, there a tuft of herbage lending a helping hand. Now clinging with our right to a none too sound ashtree which fortunethrows in our path, we lean cautiously over the cliffside and take our bearings. Yes, there 
on our right front is the nest. Two young Ravens are plainly visible, the third is seen with difficulty, as part of the nest is hidden from view by a projecting ledge and is only to be examined by leaning over and round the cliffside.

But after satisfying our curiosity we leave the wild-looking gorge with its forbidding-looking crags and boulders, a spot nevertheless well suited for Corvus corax, whose very croak is suggestive of gloomy surroundings.

The keeper tells us that in many years' experience he has never known a Buzzard's eyrie to face the west, and we fully endorse his opinion from all those which we have ourselves examined. We are unable to assign any cause for this, but the fact remains. Per contra, the Raven for preference chooses a western site.

Up here we are in the haunt of the rare and local Pied Flycatcher, and although it is too early to make a certainty of finding a nest, yet we discover the commencement of one in a hollow birch.

One day, too, in the course of a long ramble after Curlews' nests, we come in contact with the still rarer White Wagtail, at which we are much delighted.

Thus ends what has been to a lover of Nature a most enjoyable visit, and one in which, notwithstanding the shortness of its period, we have been able to see much that delights the naturalist's eye. 


\section{CHAPTER II}

SOME WELL-KNOWN FEATHERED OUTLAWS

LET any one visit a "gamekeeper's larder," and he will see at once what the heading of this chapter means.

There he will see tier upon tier of his feathered favourites-Hawks, Owls, Magpies, Crows, and Jays in indiscriminate medley-trophies of "Velveteen's" skill, some wholly mummified by the elements, others again killed but a day or even perhaps an hour. Here day by day some mangled victim is added to the already lengthy list; and, worst of all, the keeper is proud of his display, telling you doggedly that a "'awk's a 'awk," and therefore any bird of this family must be injurious to his charges-the Pheasants and Partridges.

But let us visit some of these outlaws in their native fastness, and study some traits in their respective characters. Facile princeps comes the Sparrow-hawk. Large woods and plantations harbour this little firebrand among birds; it is useless to search for him in the detached spinneys and fields, though certainly he pays them fleeting visits in quest 
of prey, but the woods are his stronghold, and there often enough have we been startled by one dashing past us, almost within arm's length, whilst to see one thread its way through a thick belt of trees with incredible velocity is a sight not easily forgotten by a lover of Nature.

'T is the beginning of May: we are strolling up one of the velvety glades of a wood, when our attention is arrested by a little heap of feathers-those of a Thrush-marking the site of a woodland tragedy, and clearly the work of a Sparrow-hawk.

Dark and sombre firs, intermingled with the brighter green of the larch, now out in all its summer finery, here join the oaks and hazels. Leaving the beaten track, we advance cautiously over the soft carpet of fir needles. Our caution, however, is wasted, for a Jay, most cunning of all the feathered throng, has viewed us, and makes the wood ring again with his harsh "rark, rark." Startled Ring Doves dash out of the firs on all sides, with loud flappings, leaving their two spotless white eggs reposing on the frail basket work of tivigs. In many of the trees old nests are visible, those of the Woodpigeon and Squirrel predominating. In one tree we have the good fortune to come across a family party of Long-eared Owls : these are already fledged, and are sitting in line on a horizontal fir branch. After a short scrutiny of these we continue our search, and soon find a large nest, which we pronounce to be the home of a Sparrow-hawk. To make certain, however, out with the glasses, for it is some way above us. Yes, it is the real article, as we can plainly see pieces of 


\section{WELL-KNOWN FEATHERED OUTLA WS 21}

down clinging to the edges of the nest and the adjacent branches. Tap the tree smartly to see if her ladyship is at home, for sometimes this Hawk is a very close sitter. No bird leaving, however, we begin the ascent. It is a larch we have to climb, and those who have tried will know that, as a rule, they are not pleasing trees; but at length we reach the

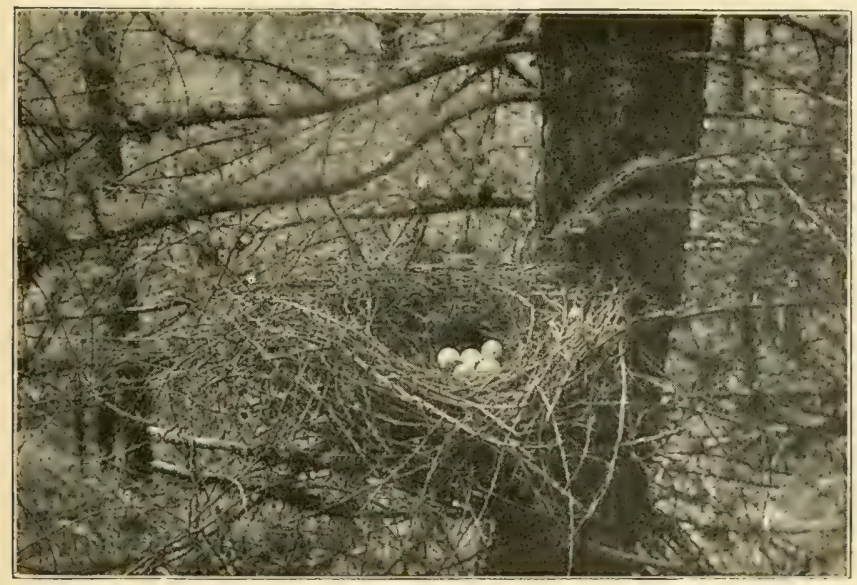

SPARROIV-HAWK'S NEST.

May 18, 1903. Wales.

nest, which, built close to the trunk, on several horizontal branches, contains three splendidly marked eggs. There are indeed few prettier sights in the bird world than to look down on a nest of this species in which the eggs are still undisturbed. The eggs on this occasion are very handsome, being heavily blotched with the rich chocolate-red characteristic 
of this Hawk. But let us watch awhile, concealed in the verdant undergrowth which abounds just here, and see if either of the Hawks will return. A quarter of an hour passes slowly, and then a shadow is visible above the larches, and the female, a brown gliding form, alights on a tree adjoining the one containing the nest. After a short scrutiny to see if all is safe, she flies on to the edge of the nest, where she sits surveying her treasures.

Move suddenly: with a wild scream she is off to what she considers safer territory. We also leave, with a hope that laziness or the denseness of the timber will prevent the keeper from discovering her secret.

'Tis the third week of leafy June when we next visit this nest, which we are pleased to see is still safe and intact; and now let us watch the five nearlyfledged young Hawks being fed by their assiduous parents. At this period of their existence they require a large supply of food, and in consequence the old birds take heavy toll from the Pheasant and Partridge chicks: here, indeed, comes the female, bearing in her talons what looks like one of the former, perhaps a week or ten days old. I Iow pleased our friend "Velveteens" would be could he see her! The nest is within easy gunshot; but we do not mean killing to-day, and so all through this broiling June afternoon we watch the IIawks bring supplics to their rapacious brood-now a Blackbird, now a Finch or young Pheasant, and nearly always "feather" — though once the male brings in a field-mouse. 


\section{WELL-KNOWN FEATHERED OUTLAWS 2:3}

We have seen this Hawk (the female) not only strike but carry off a full-grown Wood-pigeon; though as a rule Buntings, Finches, and the smaller birds furnish them with food. We are bound to admit, however, that in the breeding season nothing comes amiss to them, and it is then that they levy a heavy toll from the chicks of the game-birds, thereby justly incurring the keeper's wrath.

One day in the spring of Igoo, lying in some rhododendrons growing in a shrubbery on the confines of one of our southern woods, we witnessed a serio-comic affair. We were watching a pair of Chaffinches making their neat little home. The cock was sitting on an oak branch, cheering his busy mate with song, when a male Sparrow-hawk came gliding over the bushes and scized him within a ferv feet of us. A little cloud of feathers, one wild shriek, and all was over, whilst 1ccipiter nisus bore him off to the adjoining wood to devour at leisure. Yet within the week that female Chaffinch had procured another mate and was incubating in the selfsame spot.

So much for the Sparrow-hawk. Next on our list comes the graceful little Windhover, as the Kestrel is still called in many districts. Keepers, farmers, and other classes must be short-sighted indeed to kill, as they do, this most useful bird. No plunderer of game he, unless exceptionally hard pressed for food (we have once or twice caught him red-handed), but an unceasing and rever-tiring persecutor of the agriculturist's pests-rats, for instance, and their smaller cousins, the different species of mice. Watch 
one as it hovers on trembling pinion over yonder stubble, ever watchful for the slightest movement beneath; now it advances for a short distance, and then to its hovering again. At last game is sighted -probably a mouse-and with closed wings the Kestrel drops like a stone, and, if carefully watched, will in nine cases out of ten be seen to rise with something in its talons. Yet, benefactor though it is, it is none the less shot down, and is by far the commonest Hawk we shall find amongst the mangled remains on the old shed or tree which is utilised as a gallows for furred and feathered depredators.

This little Hawk is easily suited as to a nesting site. In the Vale of Aylesbury, where we spent many happy years of boyhood, it commonly enough laid its eggs in some deserted Crow's or Magpie's tenement (always removing the lining of roots in the latter's before using it), or else on the basin-like top of a lightning-stricken tree-a poplar for choice.

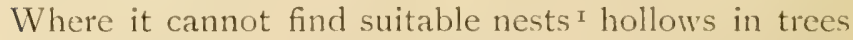
are called into requisition, whilst by the sea and in the hill country ledges and holes in the cliffs are used.

To show that the Kestrel will if necessary drive out the rightful owners of a nest in order that it may enjoy it itself, take the following extract from our diary of I 898 : "In mid April we knew of a Carrion Crow's nest containing eggs built in a large elm. We likewise observed a pair of Kestrels frequenting its immediate vicinity, and being suspicious of their intentions, kept a sharp look-out both early and late. At last one morning, after the Crow had been incu${ }^{x}$ Bromley, Kent, and its neighbourhood. 


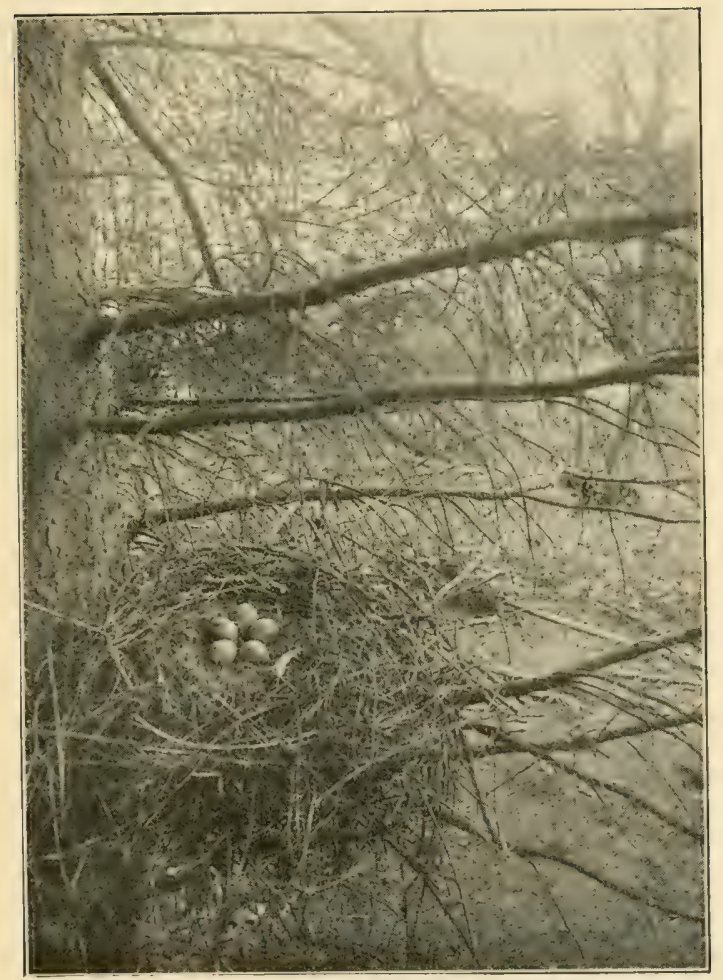

KESTREL'S EGGS IN VERY ANCIENT NEST OF MAGPIE. May I9, 1903. Wales. 



\section{WELL-KNOWN FEATHEREI OUTLAWS 27}

bating for a few days, we witnessed a first-class fight between the Hawks and their sable antagonists, in which the latter suffered severely; and not content with that, the victors proceeded to oust the eggs from the nest and then circled triumphantly round the tree-top. In due course they laid their own eggs there, and reared a nice brood. This incident was all the more extraordinary as not far off in a small spinney was a Magpie's old nest, where the same or another pair of Windhovers had nested the previous year."

These two Hawks, then, the Kestrel and Sparrowhawk, are by far the best known in this country, though in the northern shires and Scotland the little Merlin is by no means rare; and on one or two occasions we have come across the rotting form of that beautiful little Falcon, the Hobby; but as these pages deal exclusively with well-known outlaws, we will not dwell on the habits of the two last-named, though we may just say that we know of one or two favoured spots where the Hobby still breeds. Occasionally, too, a larger Hawk, such as a Buzzard or Peregrine, graces the gallows; but these, of course, are out of the common run also, and therefore we will omit all mention of them here.

Turning to the Owls, two species may generally be found on the gallows in greater or less abundancethe familiar Barn Owl, and the author of the celebrated hoot, the Brown or Wood Owl; and in districts abounding with firs the cat-like long-eared species may be seen. However, we are rejoiced to say that we personally know many keepers who refrain from 
shooting or in any way injuring these exceedingly useful birds. In Bucks the Brown Owl (one of our special favourites) was exceedingly plentiful - far more so than the Barn Owl-- and any night we could hear his soft "halloa" down an avenue of grand horse-chestnuts and elms within a stone's throw of our house. In this avenue we may incidentally add that Goldfinches bred in some numbers; and we expect they do still, as those parts were little troubled by those pests-bird-catchers.

Mais revenons à nos moutons-and visit a pair of Wood Owls, which have young in a fine old decaying $\mathrm{elm}$ at no great distance from this avenue. It is now the end of April and a perfect evening. The sun has already set in crimson glory ; sheep-bells tinkle distantly on the Chilterns; the Rookery hard by is in a perfect turmoil (are Rooks ever quiet?) ; Bats glance through the trees; a hedgehog waddles forth from his diurnal retreat in quest of worms, beetles and such-like small deer, when we are startled by a clear, loud hoot-almost overhead. Keep quite still ; and, fortune favouring us, we see his or her Owlship seated on a bare branch eyeing intently the hollow which contains the four hungry Owlets. Shortly it glides off. But it or its mate soon returns, bearing (as we can plainly see, for it is now bright moonlight) a rat nearly full-grown in its needle-like talons, which are held, as is the use of all Owls in flight, straight out behind.

All through the balmy spring night the great softplumed Owls visit their ravenous young, returning with food every ten or twelve minutes, one after the 
other; and it is with reluctance that we leave the repose and quiet of this woodland scene. This Owl is generally a very early breeder, and often enough we have found fresh eggs during the second week in March, but frequently they are not laid till the first week of April, and they appear never to exceed four in number. From pellets we have examined, we should say that rats, mice, with some of our smaller birds, form their staple food, though in individual pairs we have found little else but the remains of birds and several species of beetles; and in one nest which we looked into we found the remains of a Wood-pigeon and of several rabbits.

From personal observation we rather doubt if this species breeds every year. For instance, in the case of the pair mentioned above we noticed that although they frequented the same spot for many years they only bred three times during five seasons; and to make doubly sure of this we examined every hollow tree in the neighbourhood. Moreover, during the years that we suspected there was no brood, although we often enough watched the old Owls closely, yet we never heard the "kee-wick" of the Owlets or saw them; and this we may say is by no means an isolated case even within our own experience.

This bird, too, will not hesitate to drive another species from itsnest-hole; take the following instance : In mid-April of IS9I a pair of Jackdaws laid their egss and began to incubate in a hollow usually used by a pair of Brown Owls. The Owls were breeding very late that year, and, desiring their old home, not 
only turned the Daws out, but even killed one (presumably one of the pair, as we found the remains in the hollow together with an egg or two belonging to the Owls). This species, too, is very pugnacious at the nest, more especially should it contain young; and on one occasion one took our cap clean off in "stooping" at us.

The Barn Owl comes next on the "Death Roll" ; and how senseless it is to slaughter this pretty and useful species, so well known not only to dwellers by the country-side, but even to those who live in towns, as this Owl is very partial to an old belfry, and the noise and crowds of the city are no deterrents. If any one doubt this Owl's utility, let him examine in some chosen haunt the cast-up "pellets," and he will prove at once to his own satisfaction that its staple diet consists of rats and mice, varied now and again by a small bird, generally Sparrows, but we can well spare a few of them. We remember once finding a creeper's skull and the remains of a bat. Many a happy evening have we spent in the company of these Owls, watching them take food to their downy, hissing young-for it is only the young that hiss or snore, the old birds making a weird noise resembling the word "slirr." Sometimes this bird is double-brooded, but by no means invariably, we think: we have found Owlets still in the nest as late as September, the usual time for the first clutch of eggs, however, being the middle of April, and the egrss vary in number from three to six (we have once seen the latter number), and we believe eight have been recorded.

In woods abounding with fir and deciduous trees 


\section{WELL-KNOWN FEATHERED OUTLAWS 31}

we are most likely to meet with the Long-eared Owl, which reminds one of a cat, with its bright orangeyellow eyes and ear-tufts. This Owl's food consists largely of squirrels and small birds, and we never remember finding game of any description in its " nest," or rather we should say in the disused nest of some other bird, for it never makes one for itself. We have found its eggs and young in squirrels' "dreys," old Sparrow-hawks'and Wood-pigeons' nests. It is usually a very close sitter, but not invariably. Frequently one has to shake the bird off her eggs, but now and then we have known one take wing before the tree containing the nest was reached. It is always a hard nest to find, even though one knows a regular haunt, for should the Owl refuse to leave its eggs, even though the tree be violently shaken, there is nothing left but to climb tree after tree which holds a likely-looking nest, and we have sometimes ascended thirty or more trees in an afternoon without success. Very often several pairs breed in close proximity, and with luck two or more nests may be found without much difficulty, but this must be looked upon as exceptional. This species also is a remarkably early breeder, and eggs may usually be found by the end of March, though we have on more than one occasion found them during June, but in these cases probably the first clutch had been destroyed or taken, as we should say that this bird is single-brooded.

We are prepared, then, on the evidence given above, to pronounce our friends "not guilty" on the charge of poaching, or to plead for them extenuating circumstances. 
If the vial of the keeper's wrath is poured out against the Raptorial Birds, it is certainly doubly so on the Crow tribe ; and a pair of this family have a sorry chance of bringing off a brood in the preserves if he is at all up to his duties. In consequence the Carrion Crow is a scarce bird in many localities, and he is by no means a desirable fellow in the coverts, though we have a liking for him because of many happy hours spent in the Vale of Aylesbury, in some parts of which he abounded, probably because little or no preserving is done there. Not seldom have we lighted on half a dozen nests or more in the course of one day. This bird, we have noticed, is a very early riser, and his harsh "cra-cra-craw" may be heard long before the break of dawn; whilst with the light he can be seen quartering the ground every bit as well as the best trained pointer, and woe betide the unfortunate leveret or young rabbit that he comes across ! He is, however, in his diet generally omnivorous, readily appropriating anything that comes to hand. A sickly lamb runs but a poor chance against that iron bill, and his partiality for ducklings we have witnessed on more than one occasion. Eggs of all kinds, too, are taken greedily. His eggs also vary to a marked degree even in the same clutch, and are generally a size larger than the Rook's; but this test is not infallible. We have never known this species use the same nest more than once, but generally it returns to the same spot and builds a fresh one in a tree somewhere near the old tenement. The nest itself is a small edition of the Raven's. It is built of sticks of varying lengths-heather branches when 


\section{WELL-KNOWN FEATHERED OUTLAWS 33}

possible-and roots, and is lined copiously and very smoothly with hair, fur, wool, and in fact any soft substance, and is usually a very substantial structure; those built in trees being as a rule larger than those in cliffs. Many people confuse this species with the Rook, but (for one thing) the Crow is seldom seen with more than one of his fellows. Again, his

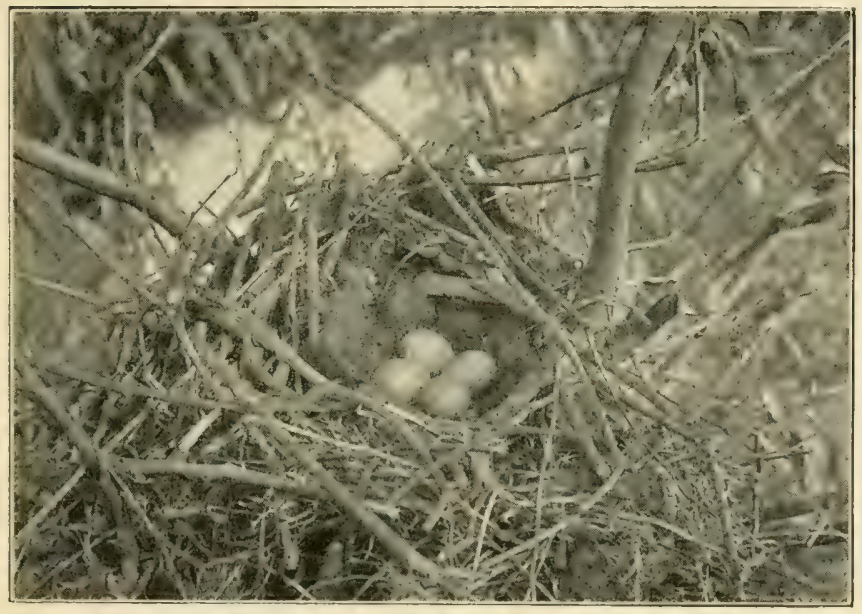

CARRION CROW'S NEST.

plumage reflects green instead of purple, the interior of his mouth is pink, that of the Rook lead colour, and his "caw" is of a different character, being much harsher than the Rook's. Occasionally, however, flocks of Carrion Crows came to roost in some plantation during autumn and winter.

Were it not for its extreme cunning the Magpie 


\section{BIRD LIFE IN WILD WALES}

would have small chance of holding its own as a British species; as it is, however, it manages to exist in very fair numbers in most parts of the British Isles, though we know some localities where a Magpie is seldom, if ever, seen-as, for example, the district for many miles round Bromley, Kent, and there it has been exterminated, presumably by trap and gun, as we have evidence of its breeding there some thirty years ago. IVe should indeed be more than sorry to see this handsome fellow eliminated from our British list of birds. He is, however, a depredator, for whilst bringing up a family all is fish that comes to his net; and then is sad havoc wrought in the coverts, amongst eggs of all sorts, though, like all the Crow tribe, the Magpie is omnivorous in his diet. He is a constant bird, and pairs for life. The old nest is either patched up annually or a new one made at no great distance from it, and until the leaves are well out no more conspicuous object presents itself to the naturalist's eye. High trees are usually selected, but failing these, a dense blackthorn is often enough chosen. We remember one in particular, two years ago (durirg a ramble in a certain part of the Principality), built in just such a situation ; and though we could almost reach it from the ground, yet so impenetrable was the bush that for some little time it defied all efforts. It was built in a clump of blackthorns and outside the clump was perfectly invisible, and was only just completed, though 'twas then, as we see from our diary, the 3 rd of May. In an adjoining bush was the previous season's nest. The nest 
under notice was rather a late one, as usually Magpies' eggs may be found by the middle of April, and these range from five to nine in number (we have seen the latter once), but six is the usual "set." Like the eggs of all this family, they vary to a marked degree, though seldom in the same clutch. We have frequently remarked that the entrance to the nest is placed on the most inaccessible side of the tree. The bird is indifferent to the kind of tree in which to build. We have seen nests in elms, oaks, ashes, firs of all kinds, and larches; often, too, when the latter are but mere poles.

We have a vivid recollection of one built in a spare larch, which, growing on sloping ground, was so thin that when the summit and the nest were reached the tree bent over at a very umpleasant angle, leaving us hanging like a fly to its underside. We succeeded, fortunately, in bringing down safely five out of the six eggs. Where the same nest is used annually, it often assumes enormous dimensions, and would in many cases fill a small cart. In winter and early spring we have often seen many of these birds together. Indeed, all the Crow tribe seem to be socially inclined during certain parts of the year; though none so much so as the familar Rook.

The Jay, quite one of our handsomest birds, happily still lingers in many woodland strongholds, even holding its own where game preserving is carried on to a large extent, and this doubtless arises from the fact that in the breeding season the Jay is very quiet, and his harsh "rark, rark" is hushed. This species is generally a very close sitter, and we have often had 
to shake the tree or bush containing the nest before the bird could be induced to quit, which she does with a loud scream of expostulation. The nest is seldom found more than twenty to twenty-five feet from the ground, often only ten; though once ${ }^{I}$ we saw one fully forty feet up a spruce fir ; but this must be regarded as quite exceptional. We have never seen more than six eggs in a clutch, sometimes only three; but the former number seems to be the usual one. Generally the shyest of the shy, this bird, when retiring to roost, may be approached fairly easily, as we have proved on many occasions. Though not gregarious, many nests may be found within a comparatively small area of suitable covert-more especially where birds of this family are not "improved" from the land. We are afraid that we camnot quite acquit the Jay of nefarious practices, as certainly he will take all kinds of eggs freelythough a field-mouse and suchlike come as a welcome change to him. In the winter acorns and grain form his simple fare.

In some "larders" we shall be nearly certain to find the pert and lively Jackdaw, more especially in the breeding scason, for though comparatively harmless at other times, Jack is at egg-time a troublesome fellow in the preserves. This bird is gregarious in more or less numbers, according to the accommodation to be found, though we have from time to time found an isolated nest, which is always placed in a hollow of some kind, trees, rocks, dovecots, and belfry towers. One we remember well in the old

I In the New Forest. 


\section{WELL-KNOWN FEATHERED OUTLAWS 37}

church tower of Dinton, Bucks, which would have filled a large wheelbarrow; the winding stairs were simply choked with rubbish. There were in this nest six eggs, and we have never seen more; four or five are the usual complement. These eggs vary to a great extent; but those in the same clutch are always of one type. We know of one very large colony in

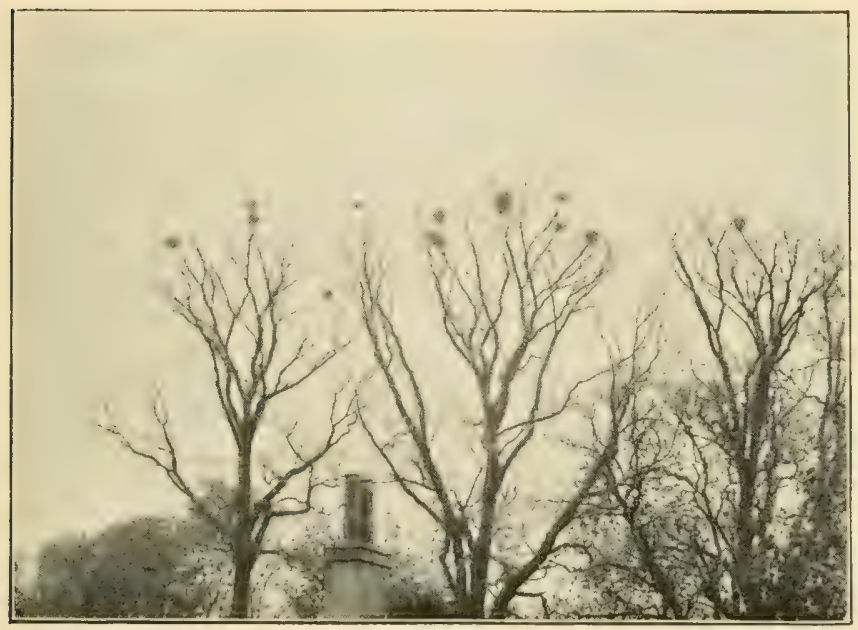

A ROOKERY.

some hollow yews situated in a churchyard in a certain part of the Principality. Indeed, this bird is a great frequenter of church and cathedral. Many used to nest in the masonry of Winchester Cathedral as well as in the college chapel, and often have we watched them from "Chamber Court" before groing into "service." Eheu! fugaces. The happy Win- 


\section{:38 BIRD LIFE IN WILD WALES}

chester days are past, but we expect that the Daws or their descendants still continue.

The well-known Rook, too, we shall find nailed up now and again, for he will, as we can testify, steal eggs, being especially partial to those of the Duck tribe. Still, who would be without his Rookery, should he be fortunate enough to possess one? Usually in lofty trees, we know of Rookeries also in the more humble yew and holly. But the elm is virtually their favourite home.

We have omitted all mention of the Hooded Crow in these pages, but except in Scotland and Ireland we shall seldom see him on the gallows, as this bird does not breed in England or Wales, though during the winter many frequent the coast-line all round our island and of course from time to time make their way inland. We have seen them ourselves in Bucks, Kent, and Hampshire. 


\section{CHAPTER III}

\section{IVITH THE RAVENS IN WALES}

THE night of Wednesday, March I2, 1902, finds Mr. Pike, the well-known bird photographer, and myself cn route for the Principality, determined, if possible, to picture the dusky Raven in its haunt.

After a somewhat tedious journey (for we are turned out several times, awaiting the convenience of sundry trains), we reach our destination, where a pair of strong cobs in a waggonette await us, to convey us to the hill country.

March in the mountains, except to a bird-lover, does not appear all couleur de rose; though the scenery is impressive enough to wake the poet's mood or charm the artist's eye, and to the naturalist many signs of returning spring are visible. As yet, except the Wheatear, none of the summer migrants are present, but the delicate-looking Grey Wagtails have returned to their beloved hill-streams and the Curlews to the moorland above. A few Golden Plover have done the same, though the bulk of them will not return till April sets in. Up here in these wild hills the busy Rooks have but begun to build their sub- 
stantial basket-work nests, whilst down south many of their luckier brethren have already begun to "set." Few birds, indeed, in this altitude, are nesting at all, the Raven being the notable exception, and by and by we will visit a nest or two of this species. Early as it is, however, we notice that one pair of Buzzards at least have started spring-cleaning, and in a wellsheltered slate quarry many of the Daws which regularly nestle there have likewise commenced operations.

During the drive from the station to the comfortable inn which harbours us during our stay in the hills, we notice six Buzzards in the air together, and the keeper tells us that he has seen as many as a dozen. This congregating is generally only witnessed in the early spring, though last year we saw five together on the 3 rd of May. Further, we are unable to say exactly the meaning of it, as we have always imagined this species to be life-paired. Of course it may be the old birds driving last year's young away, or even youngsters pairing for the first time; but in any case the same rocks are tenanted year by year, even though the same eyrie is not used. But Buzzards, like all the larger birds of prey, have tivo or three chosen spots in a range of cliff, which they call into requisition alternately.

After depositing our bags, \&c., in the inn, we start off with the keeper to see what is doing. Our path, which skirts the stream, leads us through a valley bounded on either side by cliffs broken up into precipices and turf-covered slopes. Here, in the crags on our right, a pair of Ravens have nestled time out of mind; both are soon in view and resent our 
intrusion with barking cries as we scale the rocks. We visit last year's nest, but though it contains fresh material, looks by no means the real article; and so we visit another place further down the valley, where on several occasions birds have been reared. It is not here, however, though we notice that a few sticks have been thrown together on a ledge of a rock. These sticks have been moved but a few yards from another adjacent ledge, and are the relics of some past season, for some are bleached with age. In spite of our ill-luck, we feel that there is a nest somewhere in the valley, and determine on some future occasion to investigate the matter more fully, with what result will be seen further on. Continuing our way, we breast the ascent at the bottom of the valley, following the rough and tortuous path cut in the hillside, till we reach the open moorland. Here we notice a few Meadow Pipits and Larks, and a pair of Ravens fly across the waste at a great height, on their way to some favourite feeding grounds perhaps; but at length, after another two miles, we reach a second customary haunt of the Raven. The nest is, however, still to seek; and we notice that the tree behind which it is usually built is blown down, so our dusky friends have evidently chosen safer quarters.

At this identical spot two springs ago some cruel and wanton churl took the five young Ravens from their retreat and actually hanged them in a row on some wire in the valley beneath, and last year the nest was robbed when it contained eggs.

Descending the cliff carefully, we again reach a valley, and following the course of the river, reach a 
dark, forbidding-looking gorge, running at right angles to it. Almost immediately the cock Raven leaves his watch-tower on a slab of rock, shortly followed by his partner, but she goes more reluctantly, for her nest is here, and in a very picturesque spot too. This is built in a hollow in the perpendicular cliffside, the entrance being overgrown with ivy, as if to hide it from too inquisitive eyes, and without the aid of ropes is absolutely inaccessible. The limpid waters of the stream rush over dark granite boulders, full seventy feet below, and fern fronds and deep velvety mosses cling tenaciously to the surrounding rocks. A pair of Carrion Crows pass over at a respectful distance, and a Grey Wagtail and his mate are chasing one another in the chasm below. But the Ravens have vanished, though doubtless one or both of them are watching us from some coign of vantage. By careful climbing we can reach an ash-tree growing from the cliff within eight or ten feet of the nest, and look in. It contains but two eggs, rather dark ones, and from the way the female left them we opine that she has already begun to set, though the clutch is such a small one.

After this we turn our heads towards home, wending our way o'er the misty moorland, for a regular Scotch mist has come driving down the valleys, enveloping everything as if in densest smoke, and indeed 'twould be easy to lose oneself in such an impenetrable fog ; but the keeper-good fellow-knows his ground well, and in due course we sit in front of the cheerful log fire at the inn.

Next morning we start on our travels about nine 


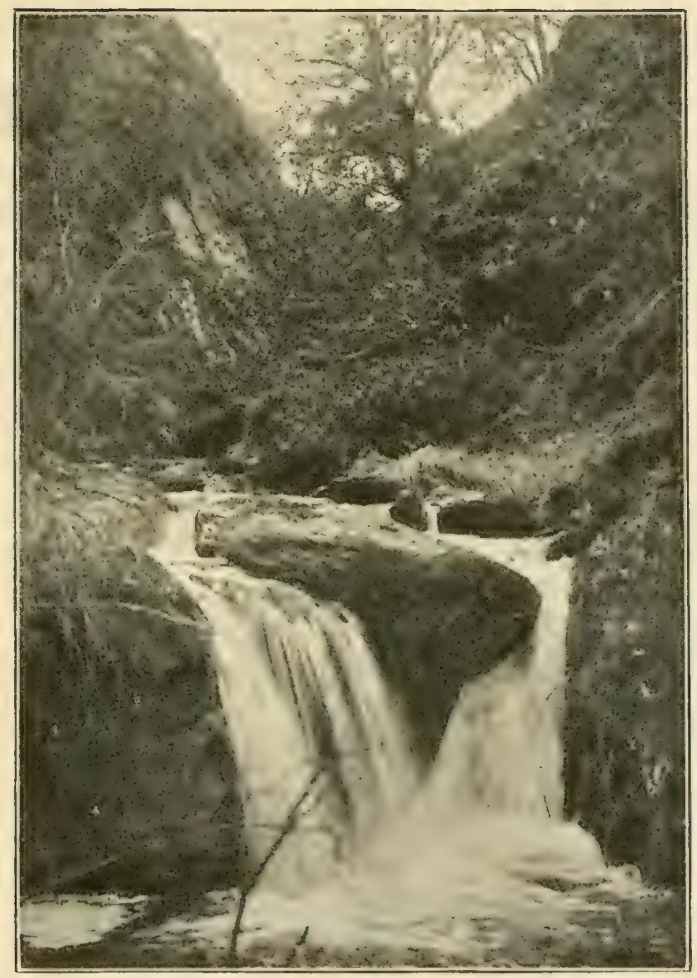

A WEISH WATERFAII, : IN THE RAVEN'S HAUNT

Iarch 17, I002. 

for some of quite the wildest country in the county, perhaps ten miles distant. Mr. Pike to-day brings his camera, and the first thing pictured is the once site of a Raven's nest ; indeed, a few sticks and a flake or two of wool have been added to the remains of the old home. Here, too, the camera nearly bids us farewell for good. Mr. Pike pins it to the cliffside with our little alpenstock whilst we investigate the old Raven's nest, and we, not knowing this, on our return casually pick up the stick, when, of course, the camera goes bounding down the precipitous slope towards a sheer drop of some sixty feet. Fortunately a mountain-ash checks its giddy career, for though we pursue it madly down the hillside as far as the precipice, we are no match for it in speed; and but for that lucky tree we should have been unable to depict any of the scenes shown in this chapter. As it turns out, no damage is done at all, and we resume our tramp; shortly reaching some perfectly magnificent rocks towering above the stream perhaps a thousand feet, though not all of them perpendicular. Mr. Pike and the keeper pursue the course of the valley, whilst we scale some big rocks on the right, where a pair of Ravens have bred from time to time. There is no nest just here, however; but seeing a Raven fly across the valley, we follow the course of the cliff and await the arrival of the others. Whilst sitting down enjoying a well-earned pipe we are overjoyed to see a fork-tailed Kite sail across the ravine towards an oak wood growing on the other side. Poor Kite! your days are numbered in the British Isles, we fear, unless drastic measures be 
taken to put a stop to the indiscriminate looting which goes on yearly in your last refuges. Two or three pairs, to our knowledge, attempt to rear their young in a certain locality we know, but with little success. Shortly after this Mr. Pike and the trusty keeper join us, the latter with the lunch, which forthwith we discuss on a convenient slope half-way or thereabouts up the cliff; and then a strange thing happens, for from some hundred feet above us is borne to our ears what must surely be the ominous croaking of a Raven; and so it proves, for, lunch clespatched, we scale the rocks and are rewarded by seeing a Raven leave her nest in a well-nigh unapproachable precipice. However nildesferandum; "aut corvus corax aut niluil" is our motto, and eventually, after a severe climb, we are sitting on a great grey slab of rock, hanging over the valley many hundred feet below, inspecting the nest, which is built in a veritable hole in the rock, under an enormous boulder, a site which one would have thought more suited to a Daw's requirements than a Raven's. It contains five very pale eggs, with hardly any markings. After this we climb to the top of the cliff, and, crossing the moor, reach a belt of larches, where a pair of Kites attempted, but unsuccessfully, to rear a brood last year. The old nest, or a remnant, is still here, and Mr. Pike pictures it several times. Here, too, a pair of Buzzards wheel above us, squealing at intervals; for we are close to their old home, in a hoary oak, and from the size of the nest it must have been in use some seasons.

On the way home we find still another Raven's 


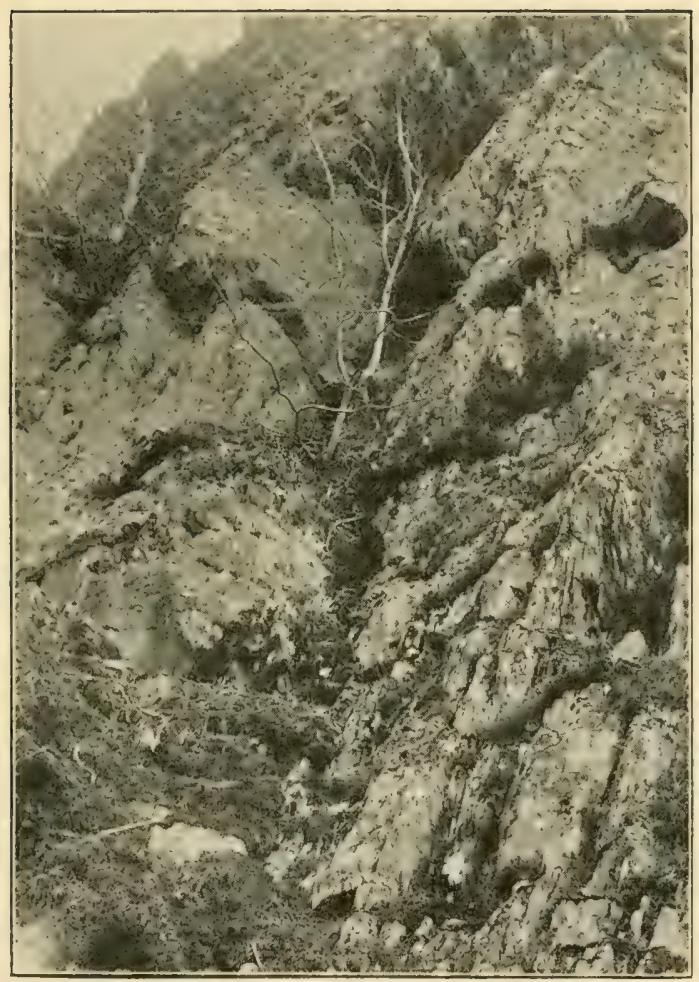

RAVEN'S NEST.

Iarch 15, 1002. Wales. 

nest, built behind an oak sapling growing from the cliffside. This contains two whole eggs and a broken one: apparently a stone has been dislodged higher up the rocks and done this damage; indeed, we think we see traces of that source of misadventure. Or can some evil-minded shepherd have dropped a missile into the nest? The eggs, though well-coloured, are very small, even for a Raven, which, in comparison to its size, always lays a remarkably diminutive egg. These are certainly no bigger than a Rook's, though perhaps a trifle longer. About one hundred and fifty yards further on a fresh nest is being built, as few birds care for a broken egg in their dwellings; in fact, there is no surer way of making a bird desert than by breaking an egg inside the nest. On our way home we hear the plaintive but pleasing note of a Golden Plover; so one bird at least of this species has returned to the hill country, the exact date being

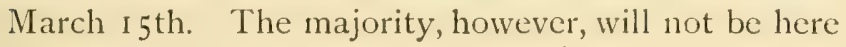
till a month later.

The following day we all set out for a wood, where a pair of Kites attempted to rear a brood some four or five years back; and indeed they would have done so, but one Sunday, when the young Kites were nearly ready to fly, some good-for-nothing fellows, mouching about, came across the nest and promptly looted it. The Kites have not bred there since. The pity of it!

Monday, March I 7 th, dawns as fair a March day as one can wish for, and with full kit of ropes, crowbar, and camera we start for the first Raven's nest, which we found a few days back, intending, if 
possible, to picture it. On our way we are gladdened by seeing three Wheatears, the first harbingers of spring. As we near the dingle containing the nest both Ravens leave it, and shortly we proceed to business. As the top of the cliff is virtually a bed of solid rock, we are unable to drive the crowbar into it, and so another plan has to be devised. Eventually we climb to a birch-tree growing from the cliffside and some eight or ten feet above the nest, and tie both ropes to it. We then sit astride the tree, while Mr. Pike and the keeper gro to the bottom of the dingle. Here Mr. Pike is tied into one of the ropes, and we haul him up the rocks. With some difficulty he succeeds in photographing the nest, which still contains but two eggs; so clearly we were right in our surmise that the Raven was sitting on these when we were visiting the nest a few days back. This is an abnormally small clutch, and we are at a loss to understand the matter, though the food supply may have been bad when the bird was laying. The Ravens at this nest are in no way demonstrative: one-we think the hen bird-comes back above the nest for a short time, but evinces no signs of anger.

On the way home we see a sight which one can scarce hope to witness again during a lifetime-a Kite, two Buzzards, and a Raven in the air together. The Buzzards are sailing beautifully in spiral curves, each taking a reverse course; the Raven is barking angrily at our intrusion, for we are not far from his nest; whilst the Kite glides straight over the valley, no doubt to his chosen haunt. 


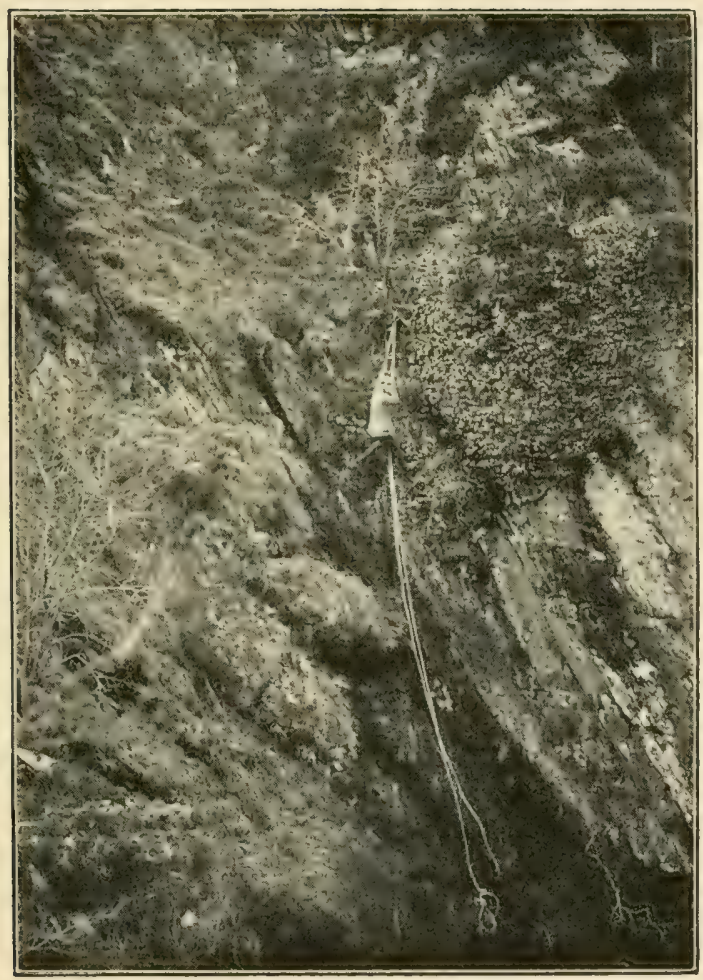

"FACILIS DESCENSUS AVERNO."

The author descending to a Raven's nest : built in a prectpice about 150 feet high. March 17 , 1902. Wales. 



\section{WITH THE RAVENS IN WALES 5:3}

The next morning we start for the valley which we visited first on our arrival in the hills, and soon see what is presumably the cock Raven sitting on a rock above last year's nest. Scaling the cliff, we find that no further alterations have been made in it, so following the course of the rocks we eventually drop on the secret. This nest is in a most accessible spot

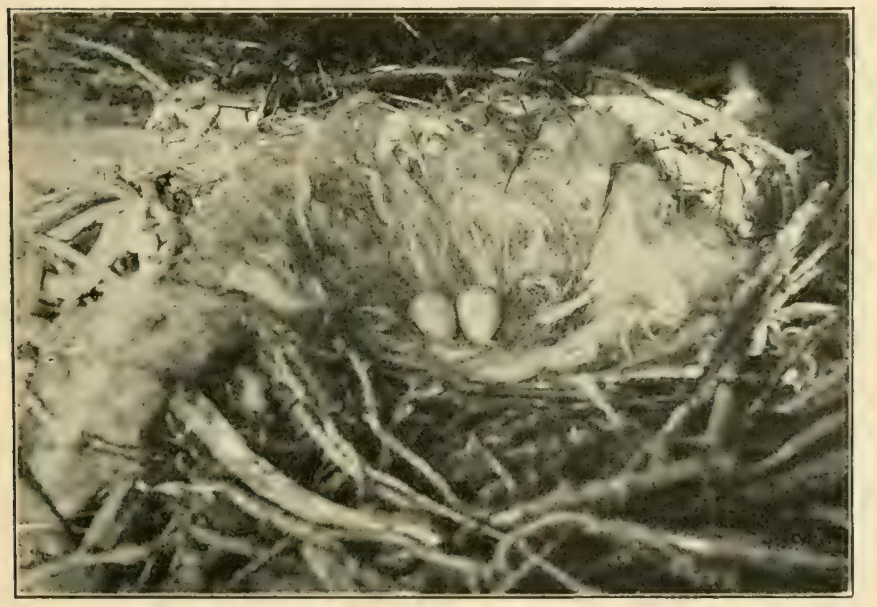

RAVEN'S NEST IVITH TIVO EGGS.

March I9, I002. WVales.

(which is rare with the Raven's home) and, built on a grassy ledge behind an ash-tree, might well have escaped observation from the fact of its being so conspicuous. It contains one rather pale-coloured egg, which feels very warm to the touch ; but we can hardly think that the Raven is "setting" on this solitary one. In the afternoon we visit yet another 
eyrie, built in a spot quite inaccessible without the aid of a rope. We fear that there has been foul work here, for we see but one Raven, and he seems in no way disconcerted at our presence; further we find what must be Raven's feathers on the rocks beneath, and these appear to bear shot marks on the shafts. Here too we nearly come to terrible grief, as whilst leaning well over the cliff, endeavouring to peer into the nest below, the keeper, who is holding us back by the anliles, begins to slip, for there has been much rain recently and the ground is sloping. In spite of the dangerous situation, the keeper's remark of "Now we sha'n't be long" tickles us immensely, but fortunately we are able to pull ourselves up in time to avert a fearful calamity.

Next morning, before leaving these charming Welsh hills, we "photo" the Raven's nest which we found yesterday, but the afternoon sees us en route for the busy world, after a most satisfactory and enjoyable visit to the Raven in Wales.

Note- - IVe are informed that there were fice young Kites in the nest which was robbed on the Sunday above mentioned. If such was the case, it must be of extremely rare occurrence, for two or three is the usual complement of eggs. 


\section{CHAPTER IV}

\section{SOME BIRDS OF THE STREAM I}

ChIEFly characteristic of these is the cheery Dipper, every half-mile of water boasting at least one pair of these hardy birds. How trim they look as midstream they sit on some projecting boulder of rock, looking for all the world like gigantic Wrens as they jerk themselves backivards and forwards! Presently one of them dives, and fortunate the observer who may chance to be above him when thus engaged, more especially should the water be clear, for he will be seen literally to walk along the bottom of the pool. It is a mystery to us how a bird constructed as the Dipper is can perform such antics, yet it is none the less a fact.

His nest we may find in many situations, most frequently perhaps where an angle is formed by two rocks, and should the spray from a waterfall drench it so much the better. No fear of its damping the interior of the nest, for the mossy exterior is quite waterproof ; indeed, so closely woven is it, that some force is required to tear it in pieces, and any one may

I The stream referred to is the Wye. 
easily convince himself on this point by procuring an old nest. Another very favourite site is the masonry of a bridge which spans the stream, and here we must look for it in the hollow formed by the dislodgment of a stone or in some crevice. Last year (1902) we found a nest some distance up a hole in the stonework of a bridge, and here there was no necessity whatever for the usual domed nest; but so strong was the natural instinct to build the regular type that even the top of the cavity was covered with moss. We have seen it, too, on a broad ledge of rock overhanging the stream. Large as these nests usually are, so well does the moss used harmonise with surrounding objects that it is often passed, save by the experts. The interior of the nest is made of dried grass lined profusely with dead leaves, and we have noticed that those of the birch are chiefly called into requisition. In this strange bed repose the half-dozen white and spotless egse, though four often constitutes a full clutch. Brood after brood is reared in the same nest, but a fresh lining is inserted for each new clutch of eggs. Most of the nests in those parts of the Wye with which we are familiar are made by preference up the feeder streams rather than on the main river.

Another very characteristic bird of these fastflowing rivers and streams is the charming Grey Wagtail, and few prettier sights are presented to the naturalist than a family party of these birds. Long after the young leave their home the old birds are very solicitous for their welfare, flying backwards and forwards past the intruder with shrill notes of alarm. 


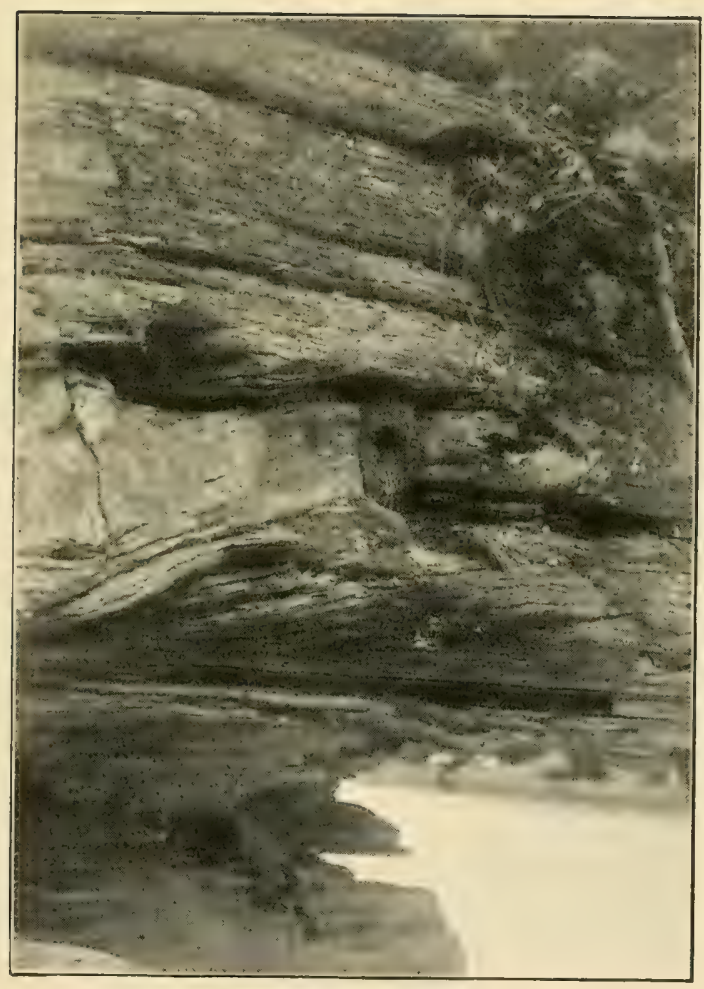

DIPPER'S NEST. WALES. 

This Wagtail is generally, we think, double-brooded, the first clutch of eggs usually being laid early in May, the second some five or six weeks later. Often enough we have seen the nest at no great distance from that of the Dipper. This nest is in this locality generally built on a ledge of rock bordering the stream, or in a crevice or hole in the stonework of a

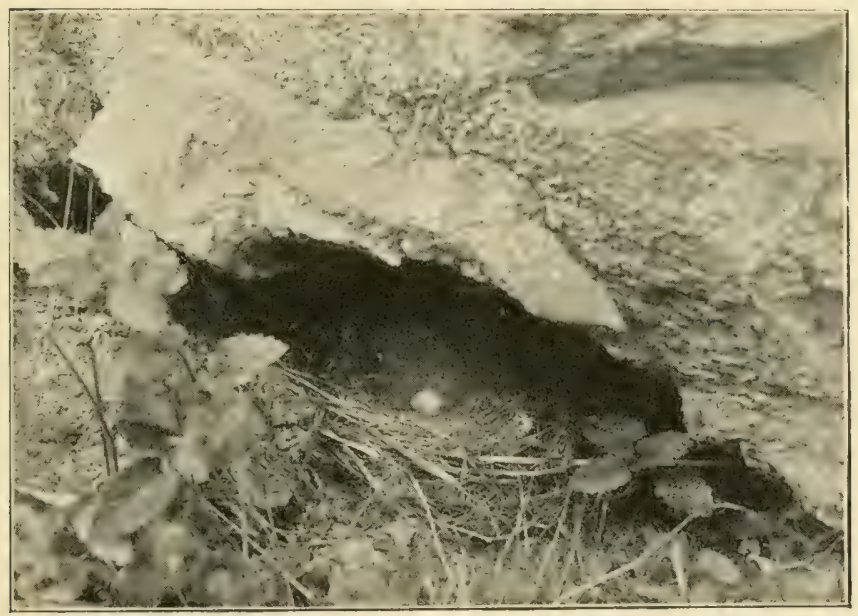

GREY IVAGTAIL'S NEST.

June I, I902. W'ales.

bridge; indeed, you will seldom find it far from water, though we know of one case where it was built in ivy covering the wall of a stable-yard with no stream at all near.

The eggs, numbering four to six, vary a good deal both in colour and the distribution of their markings. One variety is so closely mottled as to hide all traces 
of ground colouring; another has well-defined blotches and speckles. The ground colour where it can be seen is of a creamy white, the spots and blutches brownish yellow of various shades. During the winter months this species leaves its summer haunts, migrating further south, and may then be seen in small parties in most of our southern and midland counties feeding at the horseponds or pools in the rickyard in company with the l'ied Wagtail. Occasionally, but $z^{\prime} e^{\prime} y^{\prime}$ occasionally, a pair stop in one of these southern haunts for the summer. The only other bird likely to be confused with this species is the Blue-headed Wagtail, but this bird is an extremely rare migrant to our shores, and is a frequenter of pasture land rather than rockbound streams. In summer, however, the male Grey Wagtail may always be distinguished from it by the black patch on the throat, and, as above remarked, the Blueheaded species is absent from our islands in the winter. We may just say that the female Grey IVagtail has no black throat-patch, and in winter the cock loses his.

The Pied Wagtail ( $M$. alba yarelii) is not so much a bird of the river as the preceding species, but still his nest may often enough be discovered under tree roots on the river bank, and more than once we have been fortunate enough to discover the egg of that interloper the Cuckoo in it. This Wagtail is always double-brooded, the first eggs being laid the latter end of April, the second clutch during the first week in June. These eggs are of a greyish or bluish white ground colour, freckled and mottled with ash-brown and underlying markings of grey. 


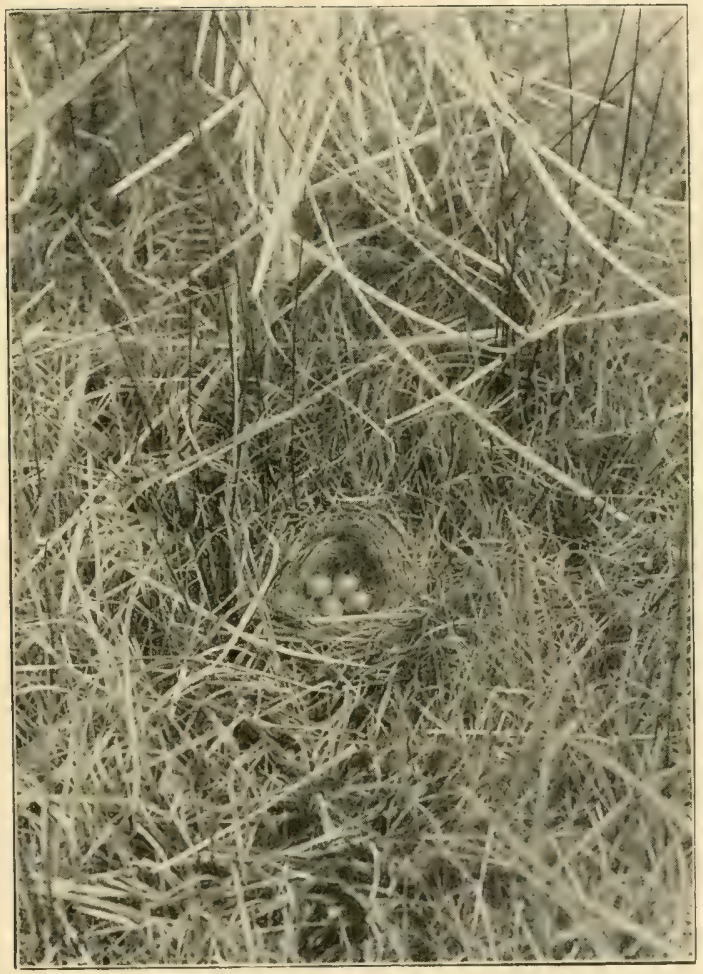

NEST OF YELLOW IVAGTAIL. 

The Yellow or Ray's Wagtail (M. raii) is a frequenter of some of the meadows bordering the Wye; but water is in no way essential to its welfare, and we have on more than one occasion seen the nest miles from a river of any kind. This Wagtail is a migrant to our islands, reaching them early in April, but a few stay the winter through in the more sheltered districts.

These birds afford a pleasing spectacle to the eye when engaged in catching flies and other insects round the grazing kine. How fearlessly they run about under the very muzzles of the cattle and between their legs when lying down! The nest, usually cunningly concealed, is built under some sheltering tuft of herbage in the pastures or under a loose slate or stone in the fallows, but last year on May 3 Ist we saw one which the veriest tiro at bird'snesting must have found, built in a little hollow in the soil and barely concealed by a clump of marsh marigolds. The eggs are not unlike those of the Grey Wagtail, but the markings are often darker and more distinct. Occasionally a pinkish tinge is observed in them. All the Wagtails' nests have a rough exterior, composed chiefly of bents, rootlets and dried grass, but are snugly and smoothly lined with fur and hair.

The fisherman's favourite, too (the common Sandpiper, we mean), abounds by all fast-flowing rocky streams, and is especially plentiful on the Wye and all its feeder streams. The angler's eye kindles at the sight of these charming waders, for he knows full well that the may-fly season is close at hand. Indeed, 
this bird has few foes, though here the Sparrow-hawk occasionally takes toll from its numbers. Here is a case in point: On May $13^{\text {th }}$ of last year, when rambling by the Wye, a little male Sparrow-hawk came gliding over a hedge adjoining the river and struck a Sandpiper fair and square on the wing. The little wader dropped to the blow, whilst for a second the Hawk seemed quite dazed by the force of his impact, but shortly recovering himself bore off his prey to a large hanging larch wood close by, where his mate and he had their large, flat, straggling nest.

This Sandpiper reaches our shores during the first week of that delicious month April, though there are earlier records; and a month after this the important business of the year commences. The four eggs are very large for the size of the bird, while the nest is very scanty, nothing more than a few dried leaves and a little withered grass; indeed, we have seen the eggs reposing on little more than mother earth, but the moister the site, the more substantial is the nest. The eggs differ somewhat, both in colour and markings, but those in the same clutch are invariably of one type. They range from buff to buffish yellow in ground; blotched and spotted with reddish and purplish brown with underlying spots of grey. Very pyriform in shape, they are always placed with the small ends pointing inwards, so as to take up as little room as possible. What a wavering, uncertain flight this Sandpiper has! Often when watching them from some leafy retreat by the stream we have almost expected to see them fall headlong into the 


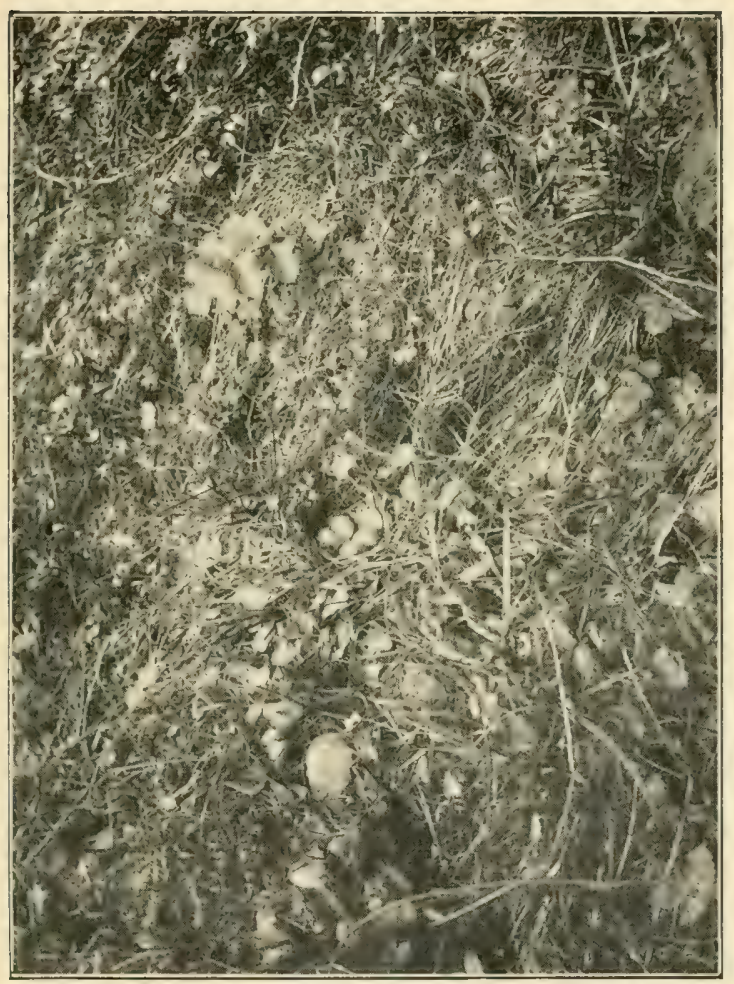

SANDPIYER'S NEST ON RAILIVAY EMBANKMENT, WALES. May 3 I, Ig02. 

water ; and yet, unsteady as its flight is, this little bird manages to reach Afric's sunny shores every autumn and return the following spring to its chosen haunt by the rapid-flowing rock-bound streams of dear old England. Near the Wye it commonly nests on the railway embankment, which runs parallel with and close to the river for many miles, and many nests may be found within a comparatively small area, though this bird is in no way gregarious.

Then, too, the gaunt fisher Heron may be seen standing knee-deep in the shallows, watching, a monument of patience, for its finny prey. This fine bird, although a frequenter of the stream, by no means necessarily breeds close to it. Indeed, many Heronries are miles from a river of any kind-but then the Heron thinks nothing of its hundred miles a day, and we have, during nest-time, seen them quite fifty miles from the nearest Heronry.

Occasionally we shall find an odd nest of this species miles from the main colony. We remember one such pair sometimes building them a nest in a large willow-tree on a secluded farm in Bucks, and had they not been disturbed, might have formed the nucleus of a thriving Heronry. Many water voles, even the full-grown ones, fall victims to the Heron; and great numbers of fish and eels are consumed by him.

We will not grudge him these; for is he not the last of our large inland birds to survive? The Kite, Buzzard, and Raven are gone, or nearly so, while the Bustards, Cranes, and other marsh birds are quite extinct; and yet people who ought to know better 
will not leave this last relic of our ancient avifanna in peace. The reason, we think, that this bird has survived as he has done is that in the Middle Ages he was preserved religiously for that noble sport falconry, whereas the other large species were still destroyed; though it is the last hundred years which have exterminated our Raptores.

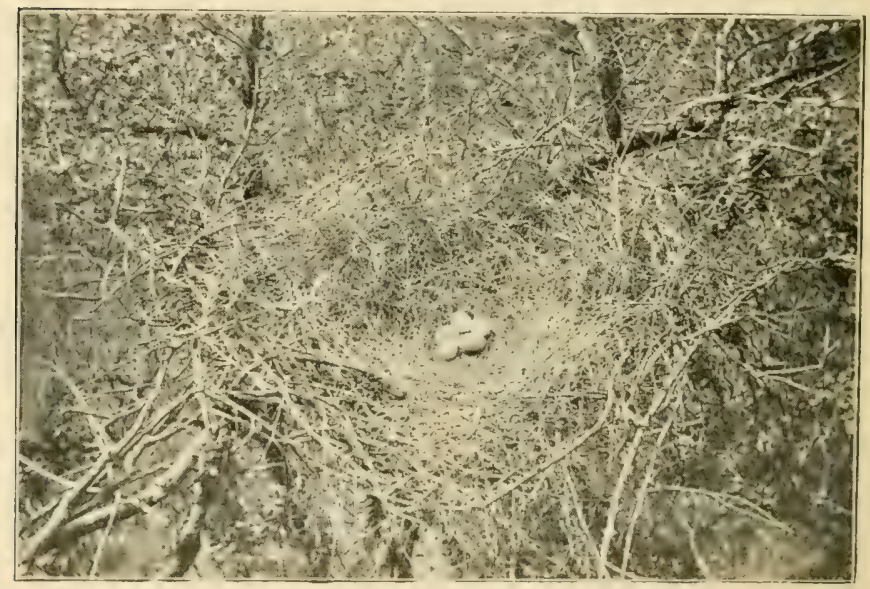

HERON'S NEST.

June 2, Is,02. Viales.

But to return to our Heron. Down south his large sreen eggs may be found by the third week in March and sometimes earlier, but in Wales not till a fortnight or more later. Usually lofty trees are chosen for the nest, such as pines, larches, elms, and oaks ; but we know of one Heronry built in very diminutive and stunted oaks, but this is the exception. 


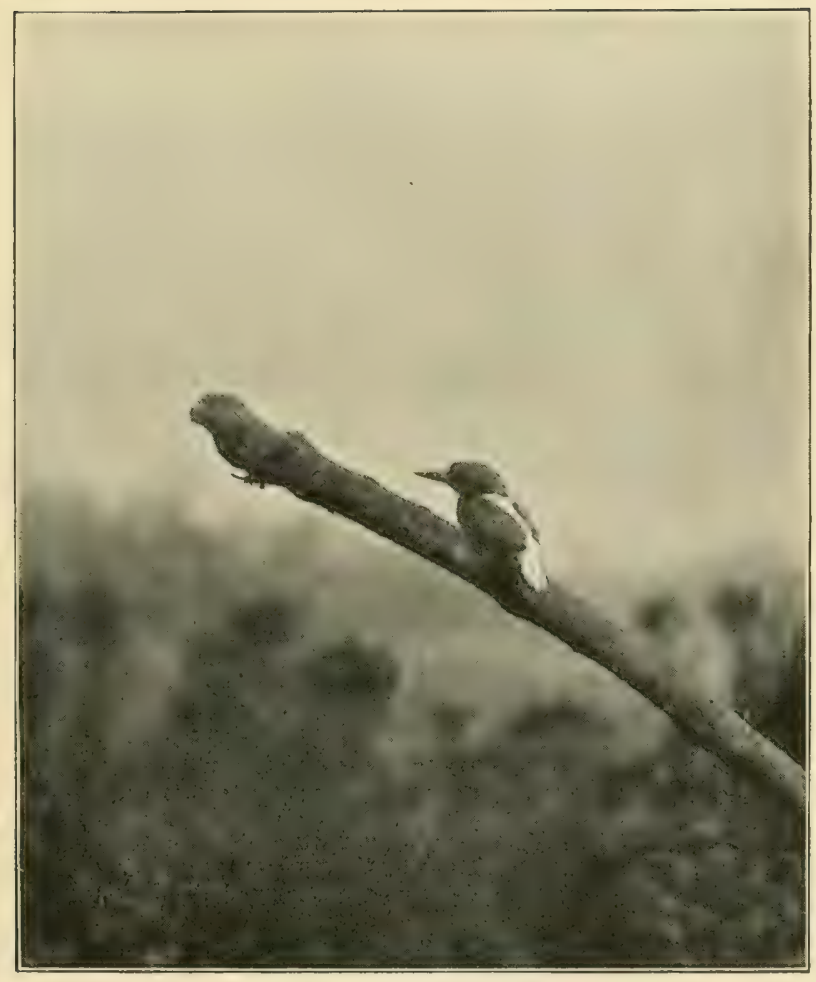

KINGFISHER. 

In some few places, too, rocks are called into requisition.

The gaudy plumed Kingfisher is another regular watcher by the waterside, but we are afraid that he is getting scarcer year by year; certainly in some localities. Here on the Wye, for example, he is far from being numerous, though we do not think that many are shot or netted. Another reason which makes this tropical-plumaged bird appear rarer than he is, is that he is very jealous of his fishing preserves, driving off any intruder with great pertinacity. Consequently we seldom find more than one pair to every two miles of river.

The Kingfisher suffers severely in very hard weather, because his feeding grounds become frozen over, and then the poor bird is indeed in sore plight. We do not think that this species often excavates a hole entirely for itself, though of course it always forms the chamber at the end of the tunnel to lay its eggs in. It is a very wary bird at the nest too, and unless there be young great difficulty will often be experienced in finding it, though the hole may be distinguished from that of the Sand-martin, by being nearly round, whereas the latter's is rather a flat cavity, if we may use such a term. Further, it cannot be well confused with the water vole's bury, for, besides being smaller, it is usually much higher up the bank out of the way of floods, so that it is fairly easy to identify it, failing a sight of the birds themselves.

Occasionally this bird will hover over the stream like a Kestrel, plunging in on the slant when a suit- 
able fish is seen; but its usual modus operandi is to wait on some stump or convenient bough till a shoal of minnows or other small fry appear, when, like a flash, in it goes and rarely returns without a captive.

In certain parts of the stream, especially where osicrbeds abound, the gay Reed Buntings have their resort, and a very pleasing sight a pair of these birds afford as they flit from reed to reed. The nest is usually to be found in the tangled undergrowth of the withies or among rank grass or sedges; and though of rather rough exterior, is neatly enough lined with horsehair and occasionally with vegetable down. The eggs do not vary much, and are of a greyish or olive brown ground, with streaks and spots of purplish black and underlying markings of violet grey. The streaks, however, are not so intricate as in the case of the Yellow or Corn Buntings. The cock bird assists his hen in the task of incubation, as we have proved on more than one occasion. Talking of this species, we may mention that whilst at Winchester College a friend of ours "drew a bow at a venture" with his catapult at one of these birds flying across the Itchen and actually brought it down! A tall story, but true nevertheless.

In the same haunts, amongst the osiers, we shall certainly meet with the Sedge IVarbler, and if there be reeds intermingled, the Reed WVarbler as well, though this last-named species is somewhat local in its distribution. Both these birds are migrants to our shores, the former reaching them during the latter half of April, the latter about the third day of May, though we have known it arrive considerably earlier.

The Sedge-bird's home we shall find amongst the 


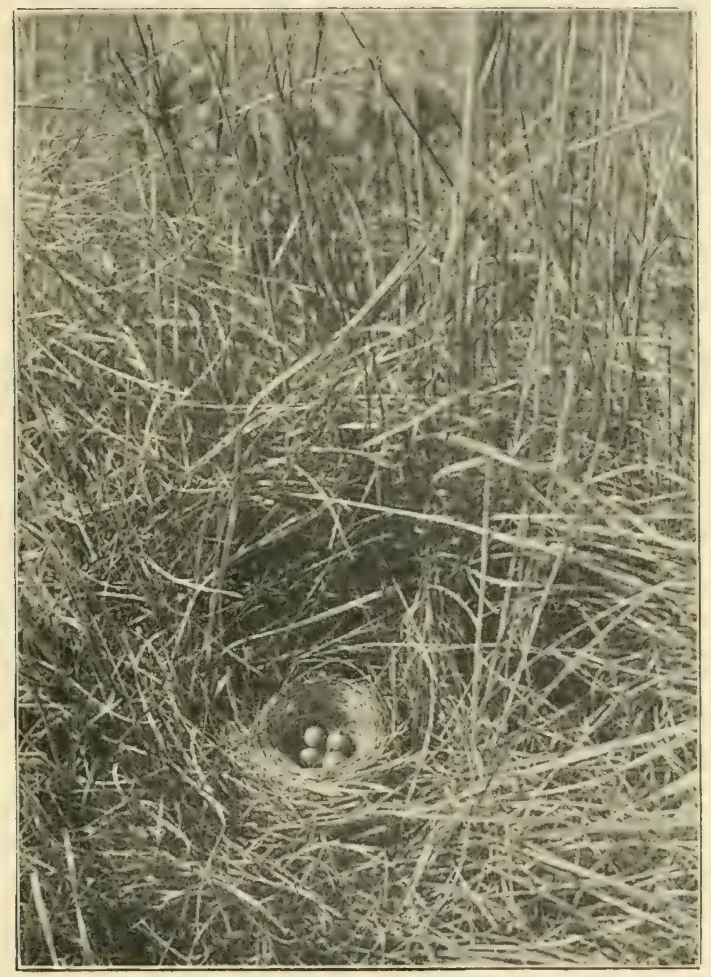

REEI)-BUNTING'S NEST. 

rank grass and tangled herbage, but the Reed Warbler's nest is cunningly suspended between three or four reeds. Both birds lay four or five eggs, but we have known half a dozen in the case of the former. The Sedge Warbler's eggs are of a yellowish white colour, spotted and freckled with different shades of brownish yellow, sometimes with a few streaks of very dark sienna brown usually at the larger end. Sometimes the markings obscure the ground colour entirely; in other eggs the spots are few and well defined. The Reed Warbler's eggs, on the other hand, are greenish white, with blotches and spots of olive brown and greenish grey, with underlying markings of grey.

The familiar Waterhen we shall certainly find in more or less numbers on most rivers, and the Wye forms no exception to this. Many nests are washed away in flood-time, but nothing daunted, our Waterhen starts again on a fresh home. The eggs, as every one knows, are large for the size of the bird, and are remarkably good eating.

We have known the shy Water-rail to breed in close proximity to the river, but the broads and reedfringed pools are his sanctuary, and here we may be fortunate enough to stumble across his rough nest. Indeed, this is a nest that we find more by accident than design.

Many Duck of different kinds frequent the stream too, especially in winter, from the spot in some wild mountain, where it starts a tiny "prill" to where it dashes into the ocean a mighty salmon river. The ordinary Mallard, or Wild Duck, frequently nests in its close proximity, though often miles from a river 
of any kind, and many of us have seen this Duck's nest in all sorts of odd places. Personally we have seen it in a deserted Crow's nest and on the pollard top of a willow. Some ten years ago we remember seeing an albino bird of this species; it used to feed in some flooded meadows with many others, and though we tried hard to get it, we were always un-

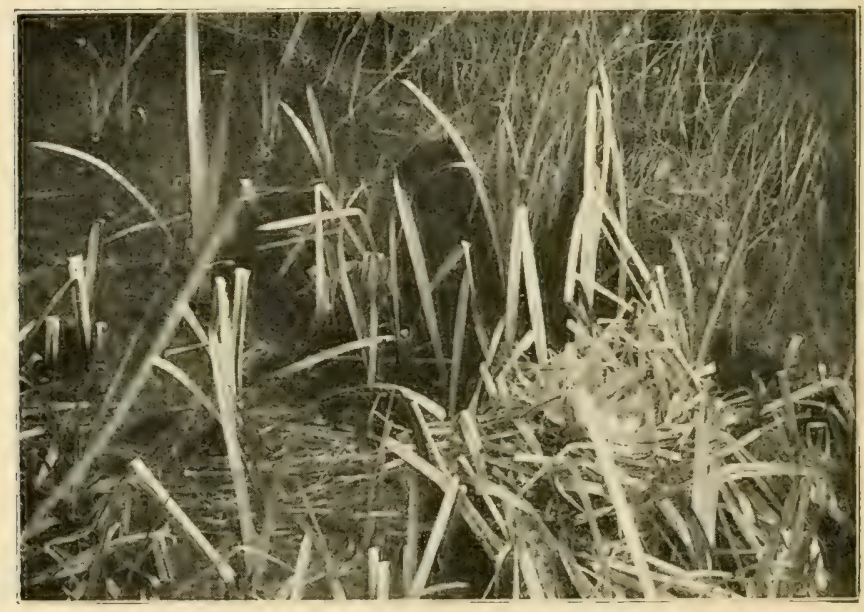

MOORHEN'S NEST.

successful. Winter is the time, however, to see Ducks on the river, and then in chosen haunts, Mallard, Teal, Widgeon, Shovellers, P'intails, and Goosanders may be seen by the fortunate ornithologist.

These, then, are the chief birds of the stream, though many others constantly nest close to it, such as the Ring Ouzel and Pied Flycatcher ; but we must bid them adieu, or, better, au revoir. 


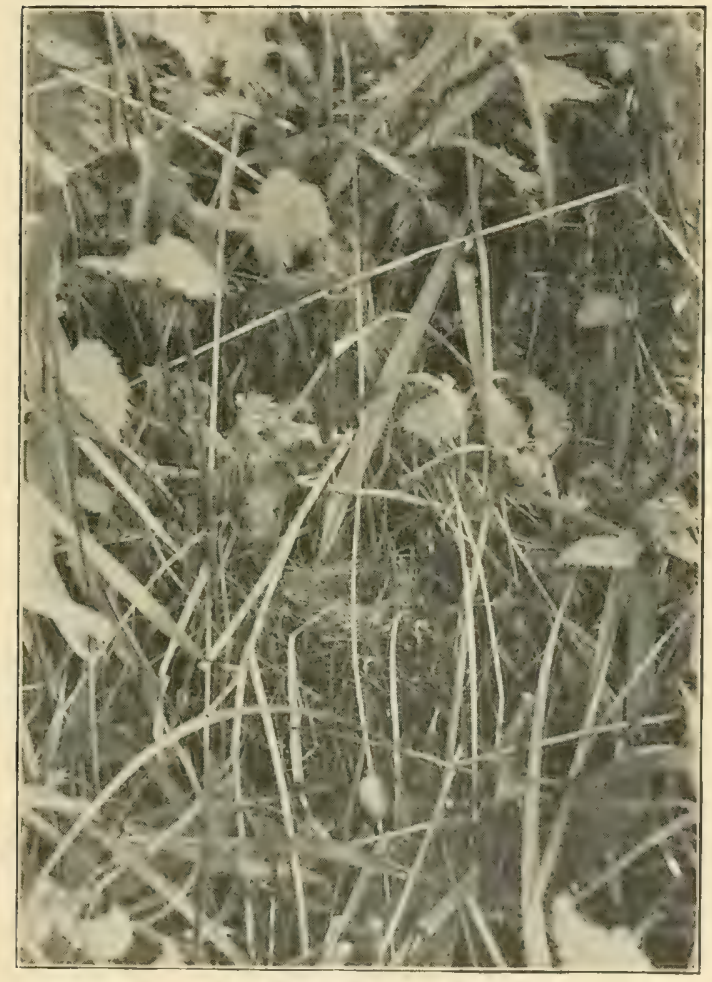

SEUGE IVARIBLER'S NEST. 



\section{CIIAPTER V}

\section{A SUMMER WITH THE BIRDS IN WALES (IgO2)}

March I 3th.-Moved my furniture into my cottage here. Six horses were used to get it up the gradient of the last mile. Visited the fir plantation above the house, and found that the badgers had returned to their "set." They were not here a month ago when I was down in these parts, and the Colonel and myself were afraid that the tenant farmer might have improved them.

March I 4 th.-Left my cottage for an inn in the hill country, reaching it about i I.3O. On the drive up from the station (Mr. Pike, my collaborateur, was with me) we saw half a dozen Buzzards in the air together, at which we were much pleased. On reaching the inn we met the keeper, and shortly started for a certain place in a valley known to us, where the Raven breeds yearly. Close to the inn we noticed a pair of these birds driving off some Buzzards from their sacred spot, but their nest, which was in the usual spot, did not on examination appear to be completed. This struck us as rather curious, for normally Ravens should be "setting" by this date. A little further up 
this valley we found a ledge where they had put a few sticks together. We expected to find an eyrie in the spot we were making for, but the nest was not in the usual place - behind a tree on the cliffside. This had been torn away by winter storms, but in a charming gorge, a mile lower down the valley, we did discover a nest containing a brace of eggs. These eggs were of the usual type-a greenish ground, mottled and freckled with several shades of greenish brown and a few specks of very dark sienna. We first found this eyrie by seeing the cock bird on the rocks above it, where he was no doubt acting sentinel. Shortly after he left his watch-tower the hen flapped out of the dingle uttering a hoarse croak or two in her displeasure. We saw fifteen Buzzards to-day.

March i 5 th. - About nine a.m. started for the $\mathrm{T}$. valley. Down a valley close here the keeper told us that during past summers he had seen a big Hawk which puzzled him considerably - most probably a Hen Harrier we think. Skirting a wooded hill, we eventually reached $\mathrm{Y}$. farm, and leaving this on our left, crossed the river by a very rickety bridge. The keeper and Pike kept to the valley, but I scaled some big rocks on the right, running parallel with the stream, where from time to time a pair of Ravens have nested. Whilst there I spied a Raven flapping across the valley at a great altitude, making for some cliffs on my right front. Gaining these cliffs, I waited for the others to come up, and whilst doing so had a splendid view of a Fork-tailed Kite as he sailed across the valley. I was looking down on his long, pointed wings and forked tail, and could not but marvel at the easy way in which 


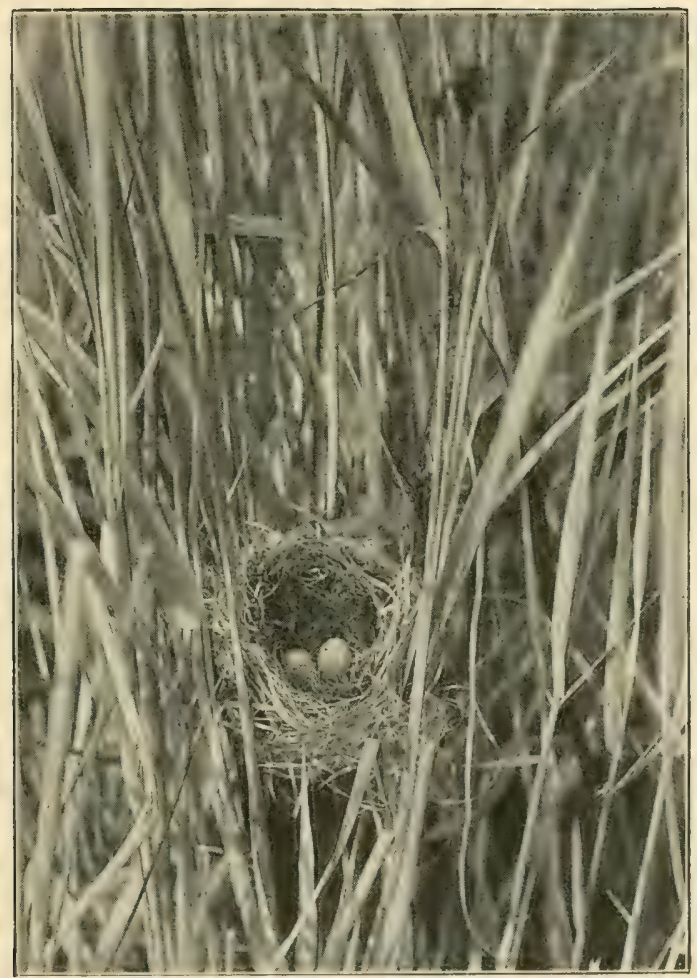

REED IVARBLER'S NEST. 

he glided through the air (hence, no doubt, one of the Kite's names-Glead). We were now half-way up a cliff fully a thousand feet above the brown trout stream, though broken up into smaller precipices some of them sheer. During lunch we heard sundry croakings about a hundred feet above us, and I climbed in the direction of the sounds, when sure enough the secret was out, for a large Raven flew from her eyric, situate in a sort of hole beneath the protection of a huge boulder of rock which must have weighed many tons. It was not an easy place to get to, and in addition there was a very high wind, which never facilitates rock-climbing, but eventually I reached it, and found that the nest contained five very lightcoloured eggs with very few markings. In addition I enjoyed a perfectly glorious view from my breezy perch. The Ravens were not particularly demonstrative. After this we struck across the moor to a belt of larches, where the Kites attempted to breed last year. P'ike photographed the relics of the nest as well as the site. Just here we watched a pair of Buzzards for some time, wheeling above a curiously contorted oak that held their ancient nest, which was of considerable dimensions. Of course it was far too early in the season for them to have eggs, but here they breed every year, and I fancy that they generally succeed in taking off a brood. Then on to the C. valley, where we soon caused considerable uneasiness to yet another pair of Ravens, and very shortly found their nest, built behind an oak sapling growing from the cliffside. It contained two sound eggs and one broken one. Very clearly a stone, dislodged in some 
way higher up the rocks, had done this mischief. This nest they had deserted, but lower down the valley we found indications of a fresh eyrie. Pike photographed the first nest, but could not get into position for the eggs as we had no rope with us. Going home we had to wade the $\mathrm{T}$. river. Reached home about 7.30, after a most enjoyable day. We heard a Golden Plover close to L. House, not far from the inn; so a few have returned to the uplands, it would seem. To-day we saw eight Buzzards.

March I6th. - Watched a Buzzard soar to a great height just outside the inn. Then up to T. dingle, where a pair of Ravens bred last year. The old nest has been blown down this winter, and the birds have deserted the gorge altogether. Then crossing the river we reached the $G$. valley, where was a very ancient Raven's nest, but no new one. This, however, Pike pictured. Then on to P. quarry and wood, where, early as it was in the season, we noticed some Jackiaws building. "Once upon a time" the Kite bred here regularly, and Pike photographed the remains of a very ancient nest in a large oak tree. The Buzzard always breeds here, and the pair in question had even started patching up two of their former homes: one was being lined with mountain grass and fern, the other with grass in a green state and ivy leaves. The former was an enormous structure built in the fork of an oak, the latter was on a ledge of rock at the top of the wood. Just before this Pike had photographed some charming falls, where in some rocks we noticed an old Buzzard's home with two bricks in it, relics of shameful work, probably done 


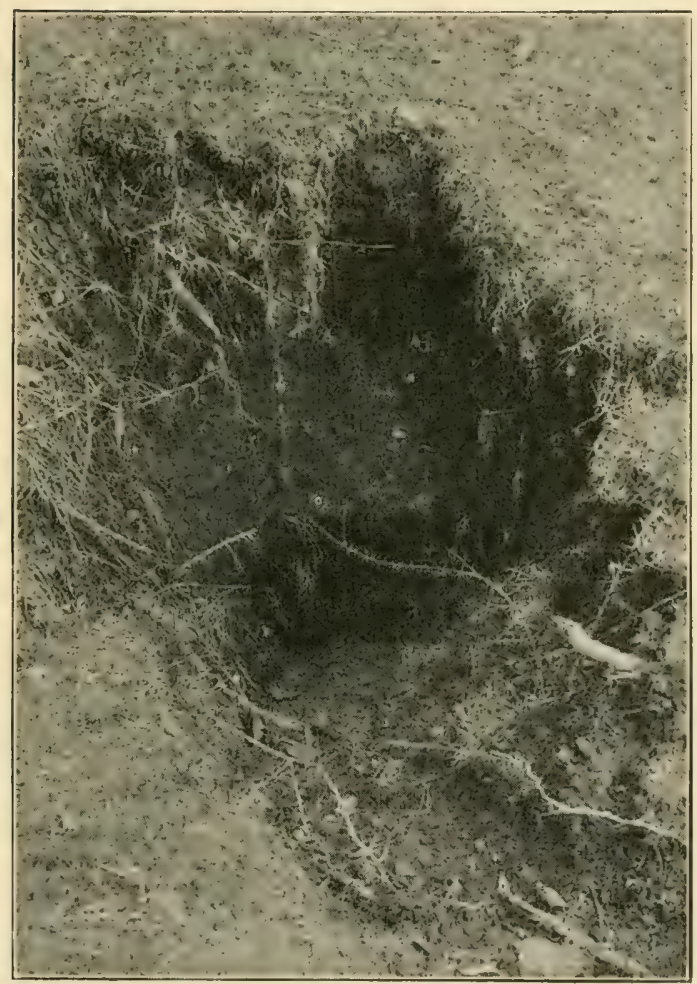

BADGER'S "SET," WALES.

March 13, 1002 . 

last year. We came out at the top of P. wood and cut across the moors, disturbing a few Red Grouse. Eventually we reached the $B$. road, taking $c n$ routc a small wood where the Tawny Owl breeds regularly. On examination the tree proved to be empty, but afterwards I heard that three esgss were laid there.

March I 7 th.-Left the inn on a day as warm as June about nine o'clock, with full kit of ropes, crowbar, camera, \&c., for the dingle where we had found the Raven's nest with two eggs on March I4th. Just before we reached the Raven's nest we were gladdened by seeing three Wheatears, probably males, the first harbingers of spring. When about one hundred and fifty yards from the gorge both Ravens flew out croaking. Shortly after this we started operations. We found that it was perfectly impossible to drive the crowbar in sufficiently at the top of the cliff owing to the solid bed of rock and a treacherous covering of moss, and at first blush it almost appeared as if we were going to be foiled in our attempt, but eventually with some difficulty I succeeded in climbing to a birch growing some eight or ten feet above the eyrie. Then I hauled up Pike and his camera to depict the nest, and he took six photos of the eggs, being the while in an exceedingly difficult position. When I had lowered him I climbed down the ropes myself to the valley, some seventy or eighty feet below, Pike photoing me cn route, and then I lowered Pike down from a different position, and he pictured the nest twice. There were still only two eggs, so either the Carrion Crows had been busy, which I doubt - though they will certainly plunder a Buzzard's nest-or else the inclemency of 
the very early spring and a bad food supply had interfered with the bird's capacity for laying. I was not very surprised at this, because on Friday the Raven left her nest as if she were "setting," and I remember remarking on it at the time. Meanwhile the keeper was fishing in the river close at hand, but he only succeeded in catching two sinall trout not worth keeping. Just before starting home we saw a fine, as well as an exceptional sight-a pair of Buzzards, a Raven, and a Kite in the air together. The Ravens, I may say, were not greatly agitated at our proceedings. One-I expect the hen-came back once, but speedily decamped. On the way home we fell in with the L. shepherd. He told us that there was a fox or two about the L. rocks; his children saw one a few mornings back. We saw another Raven at D., and Pike photographed the ancient haunt of the Kite there. Close to the river we heard the noisy cry of the Yaffle, and above the slopes of A. wood we saw a Kestrel and a Buzzard.

March I 8 th.-Left the inn about half-past nine and started up the $T$. valley in quest of the Raven's nest there. The cock, or presumably the cock, was sitting on a crag above last year's nest, and the other did not appear for some time. After examining the old nest and finding no further advancement, we proceeded along the rocks, keeping rather low down, and soon simply walked on to the nest, built on a ridiculously easy rock behind a little mountain-ash. Never have I seen a Raven's nest in such an easily accessible place. This nest, lined copiously with sheep's wool, contained but one light-coloured egg 
It felt very warm, so either the Raven had laid it but a short time, which was extremely improbable, or else she was "setting" on it. This last idea seemed more probable, because, after finding a Raven incubating two eggs, we saw no reason why this one should not be doing the same on one. Small clutch though it would have been, Pike unfortunately had not his camera with him. We now walked on up the valley, and visited a spinney of fir-trees, where a Buzzard bred last year, but barring a Sparrow-hawk and Magpie saw but little. Then back to lunch, examining a place called the Wolf's Leap en route. This is a spot where the rocks almost meet over the stream, and in olden days, when wolves abounded, must have been chosen as a likely spot for fording the river with dry pads. Lunch over, we were off once more to Cwm I., where we found another Raven's nest ready for eggs. I fear that one of the birds, probably the female, has come to an untimely end, as we found some Raven's feathers on the rocks below the eyrie, which bore shot marks in the shafts. Furthermore we only saw one Raven here, and he lept flying up to the crag where the nest was situate, as it were from some distance. Perhaps he had been in search of a fresh mate. He did not stop about the place croaking, as they will do if there is an incubating hen hard by. Saw a very interesting sight on the way home, and one which is rarely seen I imagine: to wit, one Buzzard making violent love to another. A male Buzzard came gliding over the hillside, flying straight towards a pair which were circling round one another; whereupon the female 
promptly settled on a slab of rock on the sky-line, and number two male drove the other male off. Saw several Dippers on the way home.

March 19th.-Left to photograph the Raven's nest in the I. valley. The hen left the nest when we were about fifty yards off. We found that she still only had one egg; so it would appear that she had begun to "set." This seemed very extraordinary, for the Raven usually lays four or five eggss. I pulled Pike up on the rope to the tree behind which the nest was built, and he got half a dozen photos of it. It was very windy, which did not facilitate matters. The cock Raven was especially angry, and came within an ace of striking a Daw which had ventured too close to the eyrie. In the afternoon left the hill country very regretfully, but went to pay the Colonel a visit in Herefordshire.

March 20th.-In Herefordshire. My host and I went out for a stroll in his grounds. I examined some hollow trees for a Brown Owl's nest, and eventually found what will, I think, be the nest-hole. IVe saw one Owl-the male I expect-sitting in its usual ivy-tree. We noticed a pair of Long-tailed Tits building their charming nest in a gorse-bush in the orchard; as well as a pair of Missel Thrushes doing the same in a fir-tree. Hedge Sparrows and Blackbirds were also building. In the afternoon we went to R. nursery, where we saw the Long-eared Owls last Christmas ; but we climbed up to many old nests before finding what will probably be the chosen haunt of this species. We did not see the Owls, however, though we found many fresh pellets and remains of 
small birds under the firs. We heard the "rark, rark" of a Jay somewhere in the plantation, and on the way home discovered the old nesting hole of a Lesser Spotted Woodpecker.

March 2 1st.- Returned to Kent for ten days.

March 22nd.-Noticed a Stormcock or Missel Thrush singing on the wing; also a Blackbird carolling from the top of a chimney-pot in the town, a distinctly unusual position.

March 23rd.-Saw a pair of Starlings making love to one another, but it will be an early date for their eggs, the middle of April being the usual time. A pair of Missel Thrushes must have a nest somewhere in the garden, for they are frequently flying around in a great state of excitement when I visit a certain portion of it. I cannot find the nest, however. Often, however, this species' nest escapes observation, from the very fact of being so exposed.

March 26th.-Went for a stroll in S. Park, and found a Blackbird's nest ready for eggs in an isolated clump of trees, also a Thrush sitting on four eggs. The head gardener told me that on the Igth instant he found a Blackbird's egg on the ground, and outside his house on the other side of the lane is a Robin's nest built in the ivy growing up the hedge. It looks fresh, but the gardener thinks that the birds have deserted it, as it appeared to be ready for eggs some ten days ago, I think, however, that they mean to use it, for Robins will often leave their finished nests for days before laying.

April ist.-Returned to Wales.

April $3 r d$-Whilst dressing in the morning I 
noticed from my window a pair of Hawfinches. This finch is a rara avis in this part of Wales. In the afternoon walked to the A. Rocks. These rocks are very curious in places, rising in various turreted forms, and are extremely precipitous. I noticed a pair of Kestrels, besides many Jackdaws and a few Stock Doves, but no Rock Doves. The author

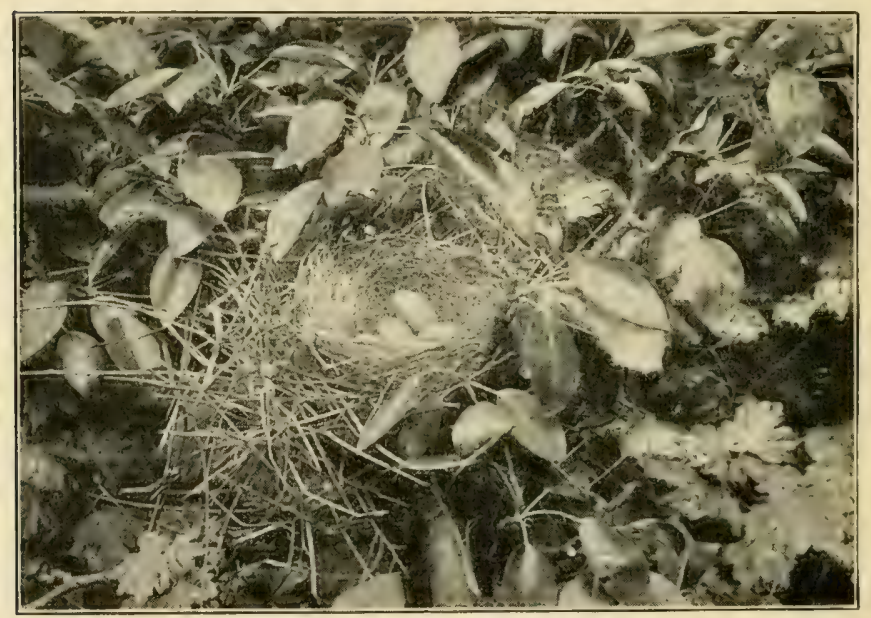

HAWFINCH'S NEST.

of the "Birds of this County" makes a serious mistake in the first edition of his book when he says that this species (the Rock Dove) breeds in these rocks; I found no trace of it, and I have it on very good authority that it never has done so. And even supposing it did breed here, it would undoubtedly be a case of tame Pigeons lapsings into 
feral; for the ordinary domestic Pigeon is descended from the Rock Dove, which, by the way, is a truly maritime species, frequenting the caverns of the seaside cliffs. It may always be known by its white rump, which is very conspicuous as it flies straight away from you. The author in question has confused it with the Stock Dove, which lacks the white rump. On the way home I heard the cheery "chiz-zit" of a Grey Wagtail, but did not see it.

April 6th.-Heard the Curlews this morning on the hill above the house. For some time I watched a pair of Goldcrests disporting themselves in a fir close to the house, where I should think they will nest. The Nuthatches were very lively, the male from time to time uttering his love-call, peculiar to the spring. To-day I was shown a bird which had becn picked up two months before by the river. It was a Kingfisher. Curiously enough, beyond smelling rather stale, it was in fairly good condition, while the feathers had hardly sloughed at all. A cottager told me that as a rule there were a pair of Tawny Owls about her cottage; also a pair of Red Hawks in a picturesque cliff close by, as well as a couple of Carrion Crows, which, by the way, are now nesting in a little spinney on the railway embankment. These latter I promised to shoot for her some time or other, as last year they proved a sad scourge to her ducklings and "gulls" (gull is the name by which goslings go in this part of the world). After luncheon I went with a couple of farmers to some rocks where one of them told me a pair of Ravens bred some eight years ago. We had a stiffish three 
miles of uphill, eventually reaching the moors, where a few Curlews and Peewits were soon on view, also one pair of Wheatears, as well as the usual Meadow Pipit. The Ring Ouzel (or Rock Ouzel, as he is called here) does not appear to frequent these uplands, which is curious, because there are many spots well suited for him. We shortly reached the rocks, and I was very disappointed in them. I very much doubt if the Raven ever bred here; he certainly does not now ; and I expect that my farmer friend mixed up the Carrion Crow with his larger cousin. I saw a Stock Dove leave the cliff, however, and from the droppings on them I should say that there was a Kestrel or two about. There are generally foxes in these rocks, and without doubt the marten-cat once frequented them, for their Welsh name implies as much. This cliff is not steep enough for the Raven's requirements, but a shepherd I met there told me that from time to time he sees a pair pass over the glen at a great height, coming from or going in the direction of L., where, he assured me, they bred in a wood; but I doubt this, for that country is much overrun.

April 7 th.-Found a Robin's nest in the lane outside my garden, built in the hole of an ivy-covered tree; also an unfinished Blackbird's, in a bramble. In the evening strolled through the fir plantations and shot a brace of Quest.

April 8th.-Heard from Mr. S., Captain H.'s partner in the moor at $T$., in Perthshire. He says that two pairs of Peregrines breed there as a rule. Captain H. is dead. Started about Io a.m. for C. 


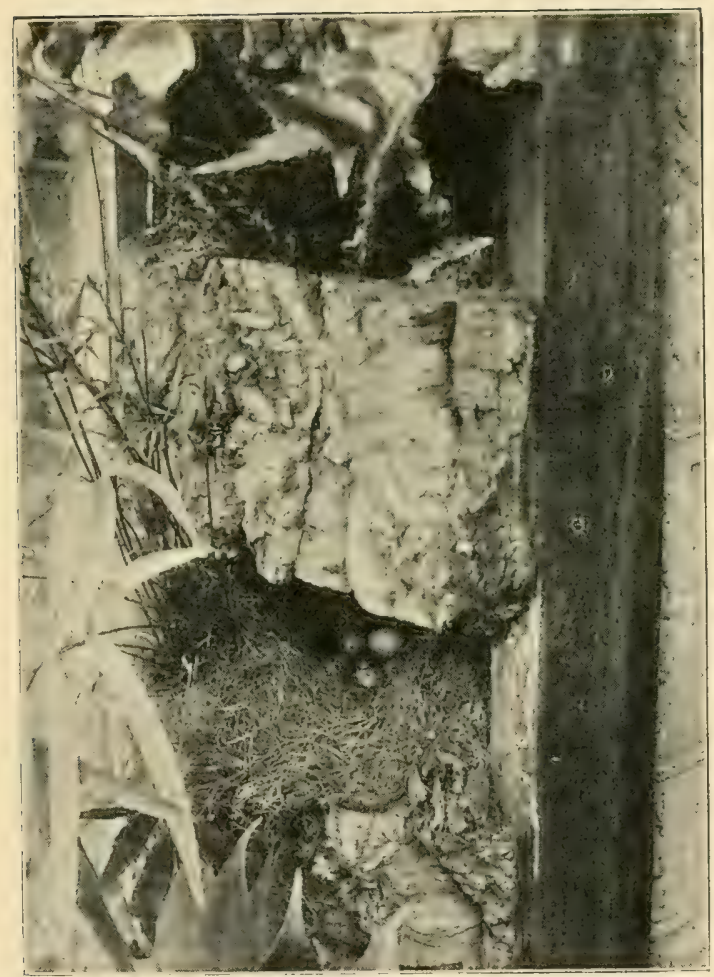

ROBIN'S NEST. 

and the Heronry which the Colonel had told me of. There is always a great charm about exploring unknown country, and to-day was particularly beautiful and spring-like. I saw no summer migrants during the walk there; they appear to be rather late this year, though of course they would be later here for the most part than down south. Passing through the sleepy little town of B., after another hour's walk I reached C. station, which I left on my right, going through the fields to the banks of the river, which is here a stream of fair breadth, but only a bubbling hill-stream up at $\mathrm{A}$, where we were the other day with the Ravens. Alders for the most part fringe the banks.

Pursuing the banks of the river then for some two miles or more, with the Dippers for company, I reached a wood where several Jays were much in evidence, many Ring Doves too, and to crown all, a pair of Buzzards, which were flapping about just above the trees on the edge of the wood. This greatly pleased me, but I made no great search for their home, though I knew that it could not be far off; but I determined on some future occasion to have a great search for it. A little further on, in a large wood running right down to the banks of the stream, I found the Heronry, quite a small establishment, consisting at present of seven nests, though later on in the season there will be, I think, a few more. The Herons had just begun to lay, three being the greatest number of eggs in a nest. The birds did not keep much above the nests, as they will when incubation is well advanced or when they have young. 
All the nests were in oaks of no great altitude, and one or two were of enormous size. One I measured was five feet across all but a ferv inches. Several nests had been blown down. At some distance from the main colony there were two rather old-looking nests, one a very small one, and underneath these I found remains of a broken egg, probably a Carrion Crow's work, for this black rascal is very partial to Heron's eggs, and indeed they must offer very tempting morsels. I waited in ambush for a long time to watch the Herons return to their homes, nor was I disappointed. It is quite a fallacy to suppose that this species incubates in a different way to other birds. Like all the feathered race, they gather their legs under them. And yet one repeatedly meets people who assure you that they either put their legs out straight behind or else one leg each side of the nest, an idea as ludicrous as the sight would be. The Green Woodpecker seems to be very plentiful about here, at which I am much pleased, for he is both ornamental and useful.

April roth.-A pair of Kingfishers reported in the boat meadow. I went up to the Carrion Crow's nest in the oak spinney, close to the line; but the birds had not finished lining it. I did not expect to find egrss, because even down south it would be full early for this species. Just after this I watched a Water Ouzel for some time, and saw a Sandpiper for the first time this year.

April i th.-Heard from Mr. G. V., a most ardent naturalist, that the Kites are not in the $C$. valley this season. Last year, and indeed for a succession of 


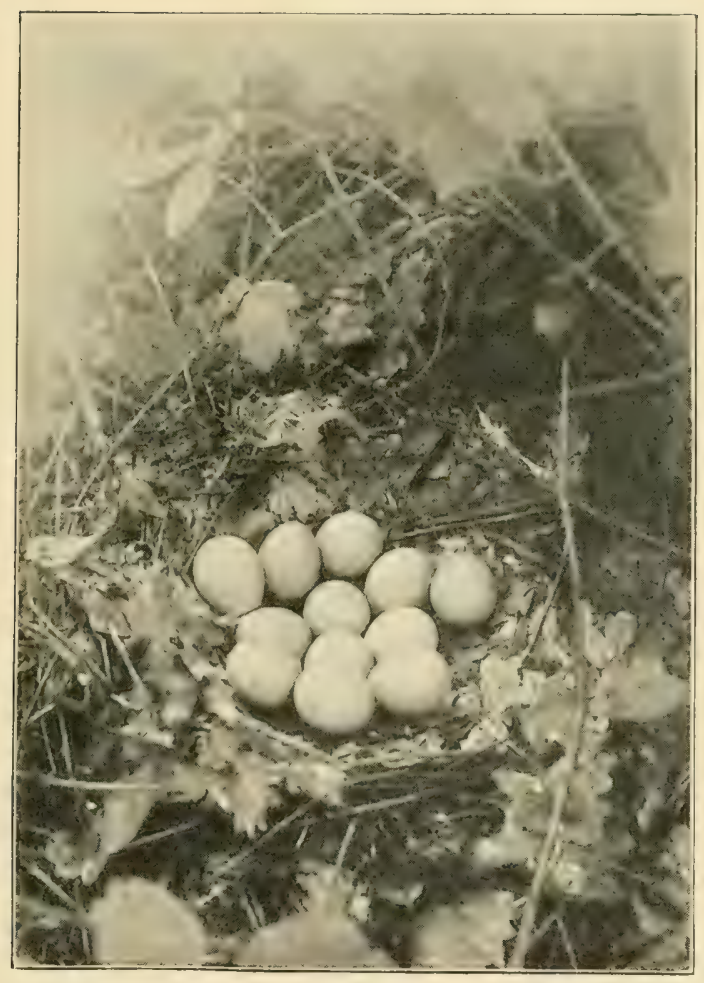

PHEASANT'S NEST. 
years, they have been regularly robbed there. This pair of Kites always have great battles with a couple of Ravens which breed in the same glen. One year, indeed, the Ravens drove them away. Oddly enough, neither of these birds are breeding there this year, but one Kite was seen two months ago, and has not been seen since. There is a Brown Owl's nest somewhere on the land adjoining my cottage under the hill, as I constantly see one hunting in the evening. This is probably the male, procuring food for his incubating partner.

April I 2 th.- Start with Mr. G. V. for the Heron wood, to find, if possible, the Buzzard's nest. Leaving our bicycles at a convenient cottage, where we noticed a Blackbird's nest in a laurel-bush, we soon got down to the wood where I first saw the Buzzards on the Sth instant, and began a systematic search for their eyrie; G. V. and I taking different routes. Eventually we met, having found nothing. A little later I climbed up to a couple of Crows' nests; one was an old one, but it had been lined with a few fresh twigs. This, perhaps, was the work of a Ring or Stock Dove, for both these pigeons will utilise an old nest on occasions, though generally the Stock Dove lays in a hole of some sort, whilst every lover of the country knows the Ring Dove's fragile wicker-work nest. The other contained five fresh eggs, and was rather an awkward nest to get, built as it was at the end of a projecting limb. It struck us as being an early date for a full clutch of Carrion Crow's eggs, considering the altitude, inclemency of the weather, and the fact that this species is not a particularly 
early breeder. Shortly after this, just as we were leaving the wood, we found a Buzzard's nest in a large oak. Just under this tree, and suspended from a hazelbush, was a dead Jackdaw, so evidently some evilminded wretch had been trying, but clumsily, to poison the large Hawks. On climbing up I found the nest built on a flat, overhanging bough, some forty feet from the ground. In it was a dead mole. It was lined freshly with green ivy leaves, but otherwise was an ancient nest, being of large size, and some of its sticks bleached with age. Then to the Heron wood, hearing the mewing cry of the Buzzards the while. We saw five Herons leave their nests, and found traces of a Sparrow-hawk's murderous work in the feathers of a Blackbird. The Buzzards had another nest in this wood, and some one had been up to it with climbing irons, as we could plainly see ; but it was too early for them to have got eggs, so we felt somewhat relieved in spirit. This nest was also lined with fresh green ivy leaves, and some mole fur was in it as well. It seemed quite a new nest, as the sticks were quite fresh; and, if undisturbed, the Buzzards will surely lay here. A pair of Magpies are building their domed nest close to the Heronry. Maybe they have done this so as to be in touch with the Herons' eggs. Their nest, almost ready for egrgs, in addition to the usual lining of fibrous roots, contained some horsehair, which is unusual. We also found a Sparrow-hawk's nest being built.

Coming back we examined a little brook, running under the railway, and here in a hole in the masonry of the arch soon found a Dipper's nest containing 
five young, perhaps a week old. There was little of the usual dome about this nest, though there was some moss at the top of the hole. In two other cavities we noticed nests, both belonging to Wagtails, one being fresh. They belonged, I think, to a pair of the grey species, for we saw a pair of these charming birds besporting themselves on the line just above. On the way home G. V. found a Peewit's nest, with the full complement of eggs. I heard the Cuckoo and Willow Wren to-day for the first time this year.

April I 3 th.-Expedition to the black bog above New House. Noticed a few Curlews about; they should be breeding now or very shortly. Peewits were much en évidence, but I found no nests of this species. Saw also several pairs of Wheatears. There are plenty of stone walls up here, where they find good accommodation for nesting purposes. I neither heard nor saw any Grouse or Snipe. Climbed to a Carrion Crow's nest, built in the corner tree of a hedgerow; but it contained nothing. On the way home I had a splendidly close view of a pair of Magpies. Usually they are too wary to allow of a near approach, so I appreciated their kindness the more. Close to my cottage, in the lane, a Nuthatch was inspecting an old Green WVodpecker's nest-hole, and I watched him for some time. In the afternoon I walked down to the river in quest of the Kingfishers. I had hardly reached the river before one darted out of some bushes growing close in under the bank: a flash of emerald and blue! I got down to the spot, but there was no nest-hole there; so 
climbing an oak hard by which leant over the water, I watched and waited. I had a splendid view of a pair of Moorhens (Waterhen is, I think, such a much better name for this bird, as one would no more expect to find one on a moor than a Grouse on the river). Presently I heard the piping cry of a Kingfisher coming from the spot I had just examined, so retracing my steps, reached the place once more. The piping continued, so keeping quite still, I awaited results. Nor had I long to wait, for shortly a Kingfisher flew out of the bank, as it were, and perched on a small branch within a few feet of me, where he sat for fully five minutes, preening his feathers and going through his toilet, before skimming off down stream. I then moved also, soon after disturbing what was probably the same bird from a stump close to a highish bit of bank. Here, sure enough, I found the nest-hole, but I did not think that there were any eggs there yet. I watched for fully an hour in the branches of an oak growing close by, but during that time I only saw one Kingfisher, which flashed past the nest-hole, uttering its shrill "seep-seep." There were one or two feathers of this species at the mouth of the hole which was well used, being worn considerably by the ingress and egress of the two birds. Whilst in my ambush I heard, on the opposite bank, the "drumming" of one of the Spotted Woodpeckers -the Greater Spotted, I think, as it was hardly loud cnough for that of the lesser species, which, though considerably smaller in point of size, makes infinitely more noise. The bird beats a sort of tattoo on a dead or decaying branch. I have been quite close to 


\section{BIRD LIFE IN WILD WALES}

the birds when so engaged, but it is quite impossible to follow the action of the bill with the naked eye. The Green Woodpecker does not make this peculiar sound.

April I 4th.-G. V. told me that yesterday he found three Long-tailed Tits' nests, in two of which the birds were sitting hard. He also told me of a good Snipe bog on the E. hills, where we may probably go next Saturday. He introduced me to the Vicar of a neighbouring parish, who is very fond of bird life. He showed me a Kingfisher's egs, that his garden boy took close here last year-one of ten. We walked down to the spot, but they do not appear to be there this year. We saw many Sandpipers and a Heron. I daresay that there is a nest of this last-named species somewhere close at hand, for I constantly see one a mile further down stream. A single Heron's nest is not of such rare occurrence as some people think. I remember one such in Bucks several years ago.

In the Vicar's garden is a Wren's nest with no lining, a Robin sitting hard, a deserted Missel Thrush's nest with a brace of eggs, two pairs of Chaffinches building, and a solitary Rook's nest in the churchyard. We noticed three Rooks scrimmaging round it. In the afternoon we started for a place called "The Three Trees" (not a "pub") on the top of a range of hills close by, to inspect a nest. The person who reported this nest said that when flushed the bird feigned lameness in order to entice him away. I was somewhat puzzled at this information, because it was too early for Meadow Pipits or Sky- 


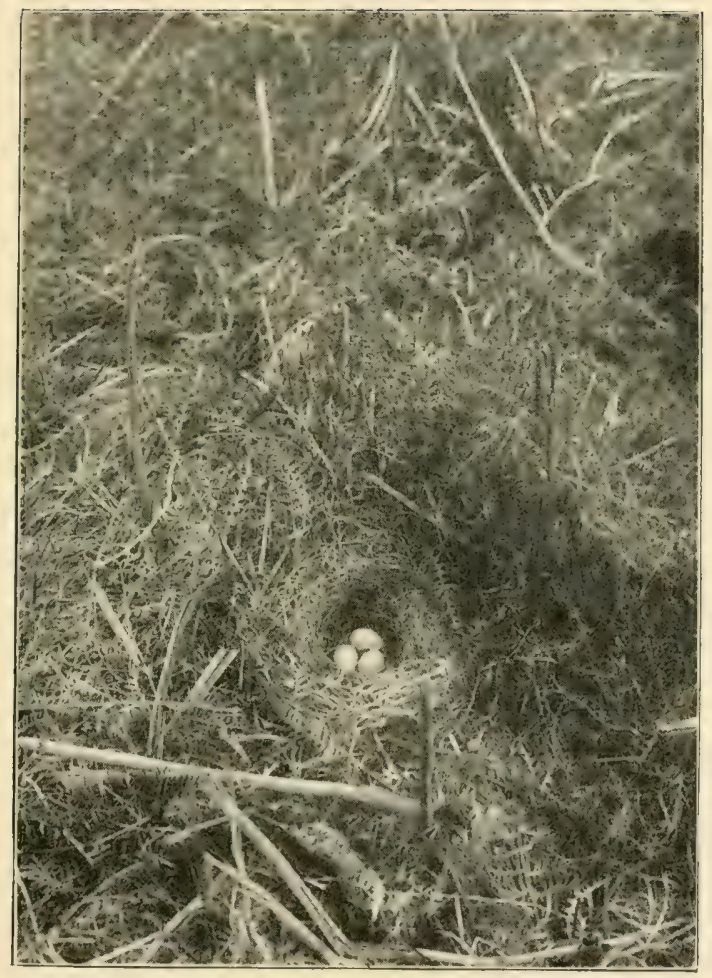

WOODLARK'S NEST.

May, 1903 Wales. 

larks to be sitting so hard, as this bird must have been doing, or even for them to have started laying in this altitude. Therefore I was all the keener to find the nest. On the way up we saw a few Meadow I'ipits and a Wheatear, but our thoughts were with "The Three Trees," which shortly came in sightsimply three insignificant trees in a row. Almost immediately I found the nest under a piece of withered bracken, which proved to be a Woodlark'srather a scarce bird in these parts, as indeed everywhere. It contained three nestlings about four days old and an addle egg. Shortly we saw both the parent birds bringing food to their offspring. The nest was a simple little structure, composed almost exclusively of mountain grass, with a few bits of horsehair in the lining. It was in a very exposed position, and therefore a very slight structure. Had it been more compact it would have attracted attention immediately. Saw the Tree Pipit to-day for the first time this year; also several Swallows and Sand-martins by the river, but no Housemartins. Came home about three, and went down to the river to see if the Kingfishers would visit their nest-hole. Sat in the oak for seventy minutes, but they never came. A Green Woodpecker came into the tree I was in and watched me quietly for fully a minute before taking wing. What an erratic flight the Sandpiper has! One quite expects to see them fall into the water as they career along just above the surface! I now descended and examined the hole, which they are only digging out after all, as there was freshly scratched-out earth under the hole, 
whilst a feather or two, which I noticed at the entrance yesterday, have been removed. To-morrow morning I must get up betimes and watch awhile, as I suspect that they only work in the early morn. A little further up stream I saw the pad-marks of an otter plainly imprinted on a mud bank.

April I.5th.-Got up at 6 a.m. and went down to the river to watch the Kingfisher's nest. IVaited in the oak for nearly two hours, but they never put in an appearance. I cannot quite make out if they have laid yet. Home for breakfast. Noticed a pair of Great Tits inspecting the hole in the apple-tree leaning over the meadow. This same hole I had previously seen a pair of Marsh and Blue Tits inspecting, but it does not seem to quite meet their requirements. The little Goldcrests have built them a snug nest at the end of a yew branch, close to the house. They are now busily engaged lining it with white chicken feathers. After breakfast started by cycle for a dingle beyond E. Noticed many Redstarts on the way, principally males; also saw and heard a Blackcap. Just after passing E. station it came on to rain. The dingle I went to (in quest of a Raven's nest) was a truly charming spot. The rocks where the nest was (for there was a fresh one there, though the birds were absent) are fully a hundred and fifty feet sheer to the bubbling stream below. There were several old nests of this species built on this cliff-one a very ancient one, which will be used by a Kestrel this summer, for I put the hen off the nest; but of course there were no eggs yet. The Ravens here must have come to an untimely end, for 
the nest was quite a fresh one, and normally should have contained young a fortnight old. From the other side of the gorge I could bring the interior of the nest quite close with the aid of glasses. It was lined and quite ready for eggs, but as the Ravens were not about, I knew that it would never come to anything. Here, too, I saw a Long-eared Owl, a rare bird about here, and I noticed that one Missel Thrush, at all events, was still in song. Usually by this date this Thrush has ceased to sing. I cannot think why the Peregrine does not breed in these cliffs, for they are well suited to his requirements, situated as they are by an adjacent Grouse moor. Coming home I climbed an ash-tree containing four Rooks' nests. Two held young about three days old; another, eggs; whilst the fourth was not finished. For some time I watched a pair of Linnets building their home in a gorse-bush this side of the A. rocks.

April 16 th.--Again riverwards to watch the Kingfishers. I put one off the stump close to the nest, which on examination proved to have been tampered with, for some one had dug it out, and I found fragments of a broken egg, so that I fear they will desert this spot, though this species is very tenacious of its nesting site. Whilst soliloquising here I was astonished to hear the well-known cry of the Wryneck, an exceedingly scarce bird in this part of Wales, and presently I saw the bird itself, as well as a Lesser Spotted Woodpecker.

The Vicar has found a Pied Wagtail's nest, ready for eggrs, under the slates of an outhouse. I went up 
to the Rook's nest in the churchyard and found that it contained one egg. This is a late date for a Rook to have just begun to lay. We sawed down the Missel Thrush's nest in the yew, branch and all. One of the two eggs had been taken by something or somebody. To-morrow we go to look for Curlews' nests by "The Three Trees," where about five pairs habitually breed.

April i 7 th. - Went out to the little larch plantation in the dingle, where the Mag.'s nest is. I put the bird off, but on examination the nest proved empty, though nearly ready for eggs, I should judge. The Kingfishers have certainly been visiting their old home, for I picked up quite a bunch of their feathers just outside the hole, and I cannot help feeling that these feathers belong to a wretched bird which had been caught by the floods during winter when at roost, for Kingfishers always roost in their old nestholes. In the afternoon went up to the Black Bog on the C. hills. Flushed two pairs of Snipe, which ought to be nesting shortly. IVe saw a good many Peewits and Curlews and half a dozen pairs of IVoodlarks. One of the latter, I think, we flushed from her eggs, but could not find them; but we did see four young of this species just out of the nest. The Whinchat arrived here to-day. I saw a Sparrowhawk quite close to the L. schools.

April I 8 th. - Above the house, on the breast of $\mathrm{R}$. hill, both heard and saw a Ring Ouzel. I should say that a pair would nest in the dingle up there. Found the Tawny Owl's nest in a hollow stump, utilised as the corner post of a hedge. This stump was a bare 


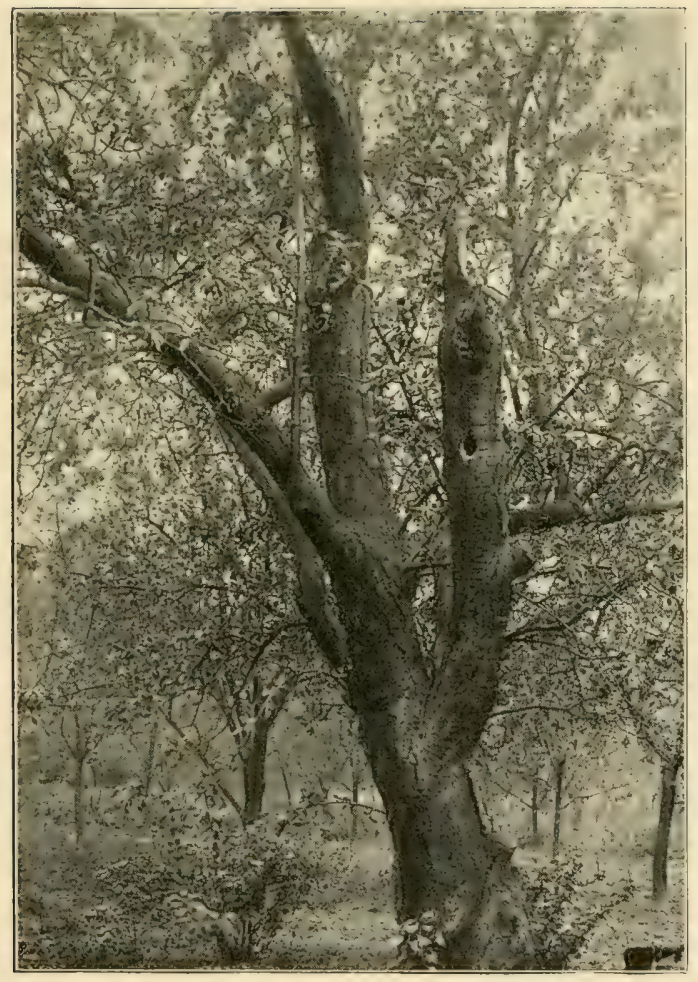

LESSER SPOTTED WOODPECKER'S NIST HOLE. 

four feet in height, and I could look down on to the sitting Owl. Poking her off, I found three Owlets just hatched, and the remains of a long-tailed fieldmouse. I should certainly never have thought of looking for a Brown Owl's nest in such a situation ; but as I passed this stump rather casually glanced down it and saw her Owlship sitting there complacently.

In the rocks further up found what I believe to be a polecat's or marten-cat's earth, certainly one of the two, judging from the fur at the mouth of the bury, which I should say contains kittens. In the oakscrub, in a most insignificant tree, I noticed a Carrion Crow's nest, which contained three eggs, one very light coloured.

April I9th.-After breakfast walked up to the rocks where the polecat's bury is with the tenant farmer here. Saw several Wheatears and a pair of Neadow Pipits. The Owl's nest this morning contained, in addition to the three Owlets of course, two longtailed field-mice and parts of a young rabbit. When I saw this I was exceedingly sorry that I had shown it to the farmer, because he has the rabbit-shooting and may in consequence attempt to destroy the Owls, more especially as they are in such a ridiculousy easy place to get to. They had been safer in loftier quarters.

Left with G. V. for S. wood, where the Buzzard usually breeds. This wood is of fair size, chiefly composed of oaks, some of them being very fine trees. G. V. took the lower part of the wood, myself the upper, and very shortly discovered the nest on 


\section{BIRD LIFE IN WILD WALES}

which the female was sitting, whilst the male was on a stump hard by. The nest itself was in rather a fine oak, a tree not very easy to negotiate without the aid of irons (I may incidentally say that there were marks of them on the tree, but last year's, I think). Eventually, however, I reached the summit, for the nest was close to the top on rather a projecting limb, and found that it contained three eggs, two of them very fairly marked, the third almost spotless except for a few very indistinct blurs. There were besides a few Grouse feathers in the nest, which was lined with dried grass. Both the Buzzards were considerably agitated at our intrusion, the female especially, and she sat in a tree hard by mewing plaintively. Just after this I saw a male Pied Flycatcher, the first of the season; and very spick and span he looked after his long journey across the seas. This is a much earlier species to arrive than his cousin the Spotted Flycatcher, generally reaching our shores by mid-April, whereas the latter seldom arrives before the beginning of May, and in parts often much later than that. Adjoining this oak wood is a dense plantation of firs, which we set about searching for a Sparrow-hawk's habitation. It was an exceedingly likely spot, and we felt sure that it contained a nest, for had we not just seen the inevitable little heap of feathers on a post which spoke, though mutely, of a Sparrow-hawk's repast? It was very difficult covert to get through, as many of the firs had fallen, and in so doing had got interlaced with their luckier brethren; but in spite of this we made fair progress, finding a last year's nest 
of this species, whilst I caught a fleeting glimpse of the female Hawk gliding through the sombre firs. Just as we were about to start for home, G. V. found the real article. It was only some fifteen feet up the tree, built on two or three horizontal branches, and appeared to be ready for eggs, but I very much doubt if it will contain any before May turns, for this Hawk has a curious habit of leaving its nest finished for some time before laying; indeed, I have known three weeks elapse before the first egg was laid, but a week or ten days is the usual interval. There were one or two fir-twigs in the nest with the green shoots still on (as is the almost invariable habit of this Hawk), as well as a few flakes of down. On the way home we found several Robins' nests and a Long-tailed Tit's (the bird was sitting hard in this latter, with her long tail pointing out of the hole over her head).

April 20th.-I inspected the Goldcrest's nest in the yew, and found that there were no eggs as yet, and later in the day G. V. and I looked up the Brown Owl's nest in the stump on the hillside, as well as the pole- or marten-cat's bury. We watched the aerial evolutions of a Kestrel for some time over the hillside, and I almost think that a pair mean to nest in the ravine there later on. G. V. thinks that the bury belongs to a marten-cat - a rarity indeed. The Owls appeared to be flourishing, and we found the badger "set" well used. I noticed that some one had been up one of the larches in my largest fir plantation, after what I take to be an old Sparrow-hawk's nest. 


\section{BIRD LIFE IN WILD WALES}

On going to the Kingfisher's haunt we found that they were making a fresh bury, close to the ruins of the old one, which is satisfactory. After tea, hearing a Woodlark singing close to the house, we investigated matters, but failed to find the nest, though we saw the cock as he came earthwards. We also saw a brace of hen Pheasants in the oak scrub. G. V. stayed to supper, after which I walked part of the way home with him, hearing a bird-note with which we were not acquainted. The Wheatear was still singing as late as 8.30 .

April 2 Ist.-A wet day with. fitful bursts of sunshine. Looked for the Woodlark's nest above the house, but unsuccessfully. The Goosanders were still about, and I saw a Drake and two Ducks of this species fly over me at no great height, as I could see the black and white plumage of the former distinctly, but I cannot think that they mean to breed here, though it is certainly a very late date to see them so far south. The only known spots in our islands which this bird favours for nesting purposes are a few localities in the Iighlands of Scotland, but they are scarce enough even there. Saw a Martin and Wood Warbler for the first time this season.

April 22nd.-I started over $\mathrm{R}$. crest to investigate the country in that direction. The wind was very strong; so much so that even when I had succeeded in lighting my pipe the tobacco was quickly blown out of the bowl. I neither heard nor saw the Woodlarks on the C. ground; but I found that the Tawny Owls were getting on well. The female, or presumably the female, was on her young, and on 
flushing her I found the remains of several longtailed field voles. I then went right across the moors; but beyond a few Curlews, Peewits, Meadow Pipits and Skylarks, saw little bird life. After going some four miles I found a Carrion Crow's nest in a thorn hedge, only some ten feet from the ground. It was a new one too, but did not contain eggs. The Crows had doubtless made their nest in such an easy situation for want of a more suitable one. It now became bitterly cold, and sleeted continuously; but making a long circuit of the barren moorland, I at length reached another watershed, where in some rough fields I was very close to some Curlews' nests, but I did not spend much time over them. On the way back, when crossing a morass in the hills, I was delighted to see a bunch of some seventy or eighty Golden Plover, a pair of Red Grouse as well as some Peewits and Curlews, all together, affording a pleasing admixture of bird life.

I think probably that a pair or two of Golden Plover will nest just here, though I am assured that hitherto they never have done so. I was away nearly six hours, but the Brown Owl had not returned to her young, which were making peculiar noises to themselves. I was then sorry that I had flushed the old Owl, for the wind came rushing down the hillside and entering a chink in the stump, must have made these tiny Owlets uncomfortable. They are still blind, I notice. In the afternoon I went to L. wood to look up the Buzzards and Herons. Reached the wood after an hour's ride. Both 
Buzzard's eyries are at present without eggs; but I saw both the birds. I noticed that the two Herons' nests apart from the main colony which seemed deserted on the 8 th instant are now both in use, as a I Ieron flopped off each on my approach, and further on still I discovered two more nests occupied: so at present this Herony consists of eleven pairs - a small but select company. Saw several eggs on the ground which the Crows have suclied, and lying up for some time, had the felicity of watching one of these sable villains plundering a nest, taking advantage of the absence of the sitting Heron. The Magpie which has nested in a tall oak close to the main I Ierony has laid five eggs, and the black horsehair employed in the lining again struck me as being very unusual.

The young Dippers under the bridge are progressing well, but the Wagtails there have not started laying yet.

April 24th.-To-day my chief object was, if possible, to find a Fork-tailed Kite's nest. The day fortunately turned out fine. Leaving my velocipede at $Y$. farm, I crossed the $T$ river by a very rickety bridge. Then, working the rocks in the D. valley, where the Raven's nest is that we discovered on March i 5 th, I saw a Buzzard, but do not think that there was an eyrie anywhere close, judging from the bird's actions. Then across the moor to T. wood, which "once upon a time" always held a Kite's nest. There was not one there to-day, however, though I had a great search. The Buzzards, too, are not breeding in the rocks facing 
this wood, as they did last year; but I saw one close by. In the wood itself I found a Crow's nest with four rather pale-coloured eggs, and saw a pair of Tawny Owls. Then on past the G. rocks, where the Buzzards bred last season, and turned short up the C. valley close by, where I immediately viewed a Buzzard soaring grandly over some big rocks. There was a nest here, for when about a hundred yards from the rocks in question the female left them, revealing the secret; but through marking the spot inaccurately I lost some time before finding it. It contained three eggs, very similar in appearance to those I found in the G. rocks last year, and were undoubtedly the produce of the same pair of birds; for as the Buzzard would fly, the distance between the two eyries could not have been more than three hundred yards, and the old eyrie was not tenanted. A Raven flapped leisurely up the valley, barking as it flew-no doubt on its way to a nest, and then I cut across the moors to N., where the Kites attempted to breed last year; but they are not here now, worse luck! The only thing here was a Magpie's nest, up a very tall larch, containing half a dozen eggs. A little further on was a Buzzard's eyrie in an oak, the same that we examined in March. It now contained a couple of eggs. One of the Buzzards was wheeling above me sorely agitated. Then right away to a small wood close to $\mathrm{T}$. wood, where in some rocks was yet another Buzzard's eyrie with two eggs.

April 25th.-I walked into the town and was much interested in the antics of a Lapwing which was 
mobbing a Crow. This latter had ventured too close to a marshy field where a few pairs of Lapwing are nesting. The Corncrake was heard for the first time this year, and a Lesser Whitethroat seen. By the river we saw a Heron and a pair of Lesser Black-backed Gulls, which came sailing down the river some twenty feet above the water.

April 26th.-Noticed a large nest in an oak close to the railway embankment, which may be a Heron's, as it is close here that I so often see one. The nest looks too large for a Carrion Crow's, and is certainly not a Sparrow-hawk's; but I have not been up to it yet. At present, however, it is only a foundation of sticks, as in places I can see through it. Then a visit to see the young Brown Owls; but on arriving there I was perfectly infuriated to find that they had disappeared.

I now set a trap for the marten-cat, baiting it with a squirrel, after which I put one of the Kestrels out of a tree just above the rocks. Had a good hunt for its nesting site, but did not find it, though there are several likely looking ledges which may be tenanted. What a difficult thing it is to find a nest of any kind in a big range of cliff, even a Raven's or Buzzard's, unless one actually flushes the bird from it or watches it back. We noticed that the Crow whose nest is in the oak bordering the line is sitting hard.

April 27 th. - In the morning had a very pleasant hour's ramble by the river. I first inspected the Kingfisher's haunt and found the hole well used. There were a few droppings under the hole-sure proof of its being tenanted. I then sauntered down 
the line, and was much gratified in watching innumerable Swallows hawking for flies on the embankment ; which just here is exceedingly steep and well wooded. Saw the usual Heron and the Lesser Black Backs again. I hear that these last appear on the river every year in the early spring, and do not leave it till late on in the summer. What can they be doing here? for they are in mature plumage apparently, and must surely attempt to breed somewhere, unless they are barren, which is extremely unlikely. Whilst standing under a small decaying oak, a Lesser Spotted Woodpecker came into it and searched some of the top branches for food. I do not think that he (for it was a male) saw me at all, for it stayed in the tree for fully four minutes and then, uttering its oft-repeated note, "kee, kee, kee," flew with dipping flight to another likely looking tree. I was much pleased to have had such a close view of so shy and, for this part of the country, so rare a species.

Just here the river runs parallel and very close to the line, and I caused considerable anxiety to a female Grey Wagtail-easily recognised by not havirig the black throat-patch which characterises the male; but though I searched some adjacent rocks I could find no nest. I next had a grand view of a female Sparrow-hawk in pursuit of a Sandpiper. Had it not been for my presence (for the Sandpiper took refuge within a few feet of me) she must have had it. Baffled in this direction, the Hawk now skimmed over the metals, snatching en route an unsuspecting Yellow Bunting. It caused considerable agitation among the Swallows, which banded 


\section{BIRD LIFE IN WILD WALES}

together in mobbing it. Just now I noticed a pair of Swifts, the first of the season; and this I may remark is a decidedly early date for them; as I well remember that when I was at Winchester they seldom put in an appearance before April zoth or May Day. The next find was a Robin's nest, in the embankment, containing five eggs; and a little further on a pair of Marsh Tits afforded me gratification, for I watched them building their nest in the hole of an oak. The hole was quite twenty feet from the ground, which is rather unusual, for as a rule this species prefers a hole close to the ground-sometimes almost on it. This pair were at the lining stage, for they were collecting some fleece which happened to be at the side of the line. As I went up the river bank a male Pied Flycatcher allowed me to approach within a few feet of him, which made me suspect that he had not long arrived in these parts. I could not see his mate anywhere. In the chink of a pollard willow I discovered a Wren's nest just ready for eggs, and several Chaffinches' homes built in thornbushes, none of which contained eggs. A little further on I flushed a Song Thrush from her eggs. The nest was a curious one, composed almost entirely of moss and a huge flake of wool, reminding one in this respect of a Missel Thrush's. Of course it had the usual lining of mud and decaying wood. Saw a good many Sandpipers. Leaving the river, I crossed the road and mounted a range of hills running parallel with it. There are some rather good rocks almost at the summit of these hills, and in some bushes growing at their base I noticed four 
or five Cuckoos disporting themselves. A little later a fine sight was presented, a Kestrel being mobbed by a Carrion Crow. The Hawk was sorely pressed, and cried out in alarm. Its aerial evolutions were wonderful, however, and compared favourably with the clumsy attempts of the Crow. It does not always happen this way (vide account of Kestrels and Crows in Chapter II.). I searched the rocks to see if I could discover the probable nesting site of the Kestrel. Found many pellets, which on examination I found were composed chiefly of the remains of beetles and mice, especially the former. I flushed some Stock Doves from the rocks and saw several Wheatears and a pair of Ring Ouzels, which are doubtless nesting here somewhere, but it was now getting dusk, so I was unable to search for it.

April 28th. - In the morning I had a splendid view of a male Sparrow-hawk which was sitting on a fallen tree devouring a Chaffinch.

To-day, on the summit of the C. hills, found a Peewit's nest, with the usual four eggs, in very scrubby heather, and a little further on, in some rank grass, had a great hunt for a Curlew's nest, but with no avail. By a tiny rivulet running down the moor flushed a Meadow Pipit, but could not find the nest, though felt positive that there was one there. Presently I went off to see if I could locate a pair of Kestrels in the P. rocks, and noticed both old birds on one particular cliff. Also flushed a Stock Dove from her nest in a fissure of the rocks. On coming back I found that my companion had discovered the Pipit's nest; he had flushed the bird 
a second time, and he told me that even then he would have missed finding it only his fingers came into contact with the eggs. It was the best concealed nest I have ever seen, for it was almost touching the water, and right under the small tussocky bank of the rivulet.

April 29th.-Noticed a Willow Wren building on the embankment (riverside). This is a somewhat early date. Noticed a Jackdaw come out of a remarkably small hole in a magnificent cedar, where it was nesting. The hole was so small that the bird was obliged to come out sideways, and even then seemed to experience some difficulty. Heard several Wood Wrens; they are hardly as numerous here as they are in Kent. Climbing up to a Crow's nest in a sycamare, I took the four eggs it contained for $O$. Besides being none to well marked, they were highly incubated, and I expect he will have his work cut out to make specimens of them. Besides this we saw what was certainly a Sparrow-hawk's old nest in an enormous larch. Got home for tea. Visited the trap which I had set for the marten-cat. I have visited it every day, but so far with no success. In the gully I found one of the wretched Owlets buried under some stones. This gully or ravine runs under the brow of the hill, where the stump is which contained the Owl family, so it is obvious that the wretch who killed them buried them under the loose rubble. Had a good view of a Kestrel, probably one of the pair which are frequenting the rocks close to Jones's cottage. I do not feel sure that the Sparrow- 


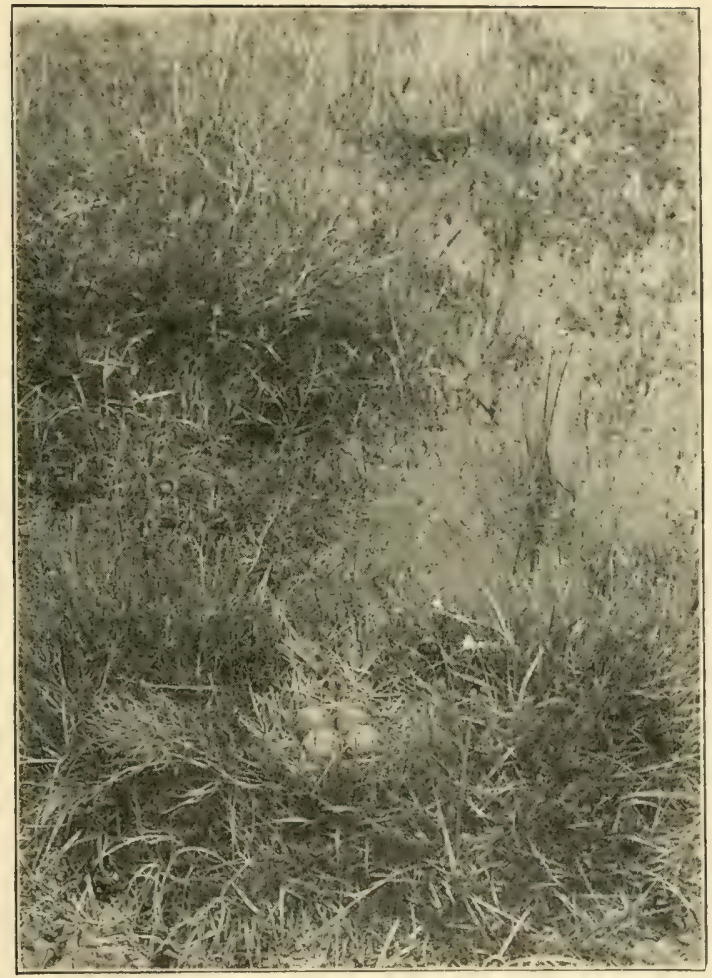

PEEWIT'S NEST. 

hawks mean to nest in the big larch plantation after all; anyway I can find no fresh nest there, and this evening I had a very comprehensive search.

April 30th.-In search of a Curlew's nest; at first we found nothing-indeed, we did not even see a Curlew-but presently I sighted one flying along a field about a quarter of a mile off, and from the way it flew I thought it just possible that there might be a nest there; nor was I wrong, for after I had crossed the line and entered the field the hen Curlew got up at once, and as there were only one or two patches of rough grass in this enclosure, such as Curlews love, the task of finding the nest was not a difficult one. It contained four eggs of the usual type. Just after this I climbed up to a Magpie's old nest in a sy'camore. This nest had got flattened out considerably, and in the distance looked uncommonly like a Heron's.

Then we visited the old church at $\mathrm{D}$., which is now disused, except by the Jackiaws and Starlings. WVe found several nests of the former species, two of which were built in dark parts of the spiral staircase leading to the belfry, and these were enormous piles of sticks. Four nests which we examined contained respectively three, five, four, and three eggs, all of the ordinary type. None of the Starlings had laid as yet. This old belfry ought to be tenanted by a pair of Barn or White Owls, but they are exceedingly rare just round here, and the fact of this disused church being without them is proof sufficient of it. In a field across the river I. we noticed a good number of Curlews, but did not trouble about them. Coming 
home we found five Robins' nests, two containing young, the other three eggs. One nest, besides being well enough hidden, was further concealed by a piece of withered wild strawberry leaf; but can this have been intentional or accidental? The eggs were fresh, and the bird certainly could not have entered the nest without first removing the leaf. Nobody, I think, about here, would have troubled to put a piece of leaf over a nest. To-day I heard from young G., who tells me that when examining the Buzzard's nest in S. wood, he noticed three birds soaring above him. Probably the third was passing at the time, and hearing the cries of the aggrieved couple, had dropped in to see what was going on. He says that there are now fifteen eggs in the Heronry, and he also has found an (Owl's nest, no species mentioned, but probably a Brown Owl, in one of W.'s woods. Besides three Owlets, this nest contained the remains of a a squirrel, a Thrush and a Blackbird.

May Day.-In the morning climbed the hill above my house, investigated the country in a south-westerly direction. Found a Peewit's nest with four eggs, and saw a few Curlews and Grouse. These latter should be nesting now, or at all events very shortly, but Red Grouse depend more on the weather for laying than any other bird, and as the present spring is exceedingly inclement, they will probably be somewhat backivard.

Visited the dingle where I discovered the Raven's nest on April I 5th. We worked the stream right up from its confluence with the main river, and our first find was a Dipper's nest, from which the young (the 




NEST OF RED GROUSE.

May, I003. Wales. 

first brood) had obviously flown, for there were many droppings underneath it. This nest was built simply on a ledge of rock, and only some three feet above the stream. A Grey Wagtail passed us, but we did not find his nest. Again we saw nothing of the Ravens, and the nest was empty as before; so now we feel sure that evil has overtaken them. Saw the male Kestrel here, but there are no eggs in the old Raven's nest which they have chosen for quarters. The cliff here is very treacherous, being composed of shaly slate and small pieces of stone, and in getting to the Kestrel's abode I had to trust to a ridiculously small and rather rotten tree growing from its side, with a clear drop of one hundred and fifty feet into the abyss below.

In this part of the country Kestrels go to nest later than their relatives down south. In the hill country, indeed, they seldom start laying before the middle or third week of May. On the way back we found a Green Woodpeclier's nest-hole utilised by a Starling ; and saw an enormous Rook's nest-large as any Heron's.

May $3 r d$. - With two companions went in search of Kites. On the way we found a Carrion Crow's nest, and questioned a ploughman and a farmer about the Kites. The former said that the birds he had seen had broad, rounded tails, but the latter, omitting all mention of tails (barring the one he was telling), said that they had long pointed wings, which spoke more of a Kite, whereas the former's narrative pointed to their being Buzzards. I think, however, that they may have been a pair of Kites looking for a suitable nest haunt after their first domicile had been plundered. 
A Pheasant's nest containing some half-dozen eggs was the next find. It was on a very exposed bank at the side of a frequented lane, but had we not seen the hen leave her treasures, exposed as they were, we might have passed them. In a stone wall not far off was an unfinished Redstart's nest.

By the way, I know of a nest of this species close to my cottage, in the cleft of an ash-tree, only about a foot from the ground.

From here we started up to a large larch plantation on the brow of the $\mathrm{C}$. hills in quest of a Sparrowhawk's nest. After finding several old tenements of this species, we found the new nest, ready for esgs. In the same plantation was a Magpie's nest containing five eggs of rather a pale type.

Returning to a field close to the line, we searched for and found a couple of Peewits' nests, one containing four the other a single egg. The former clutch was rather a curious one, as most of the markings were collected on the small end of the eggs.

May 5th.-Visited the Buzzard's eyrie in the Black Rocks, but there are no eggs there as yet. Both the Hawks were on view. This nest was lined entirely with mountain grass. Noticed a very spruce-looking Dipper by some falls, and following the course of the C., reached P. wood after about an hour's walk. We disturbed some Curlews on the way, but spent no time in looking for their nests. We first reached P. quarry, now disused, where we had noticed the Daws building as early as March I6th. There are fully a hundred pairs nesting here, but even then, unless the birds be marked carefully from their 
homes, these latter are hard to find, as there are innumerable large boulders and great shaly pieces of slate in indiscriminate medley. We examined one nest containing half a dozen eggs. P. wood is quite close to the quarry, and here we hoped to find a Kite's eyrie, but in this we were disappointed. We saw a Buzzard over the wood, and shortly were examining the nests there. The very large nest in the fork of an oak was not in use; but a seemingly fresh nest had been made in a tree adjacent. But the best used one of all, and the one they mean to lay in, was on the rock at the top of the wood. This had a nice lining of green larch sprigs, and they will certainly lay during the week. Three or four days often elapse between the laying of each egrs, so that this Buzzard will not begin to set much before the middle of the month. On the hillside facing the wood we had a fine view of a Kestrel being mobbed by at least a dozen Jackdaws; the Kestrel's movements were as usual full of grace, and he avoided the stoops of the Daws very cleverly. On the way home we saw little but a pair of Red Grouse and another Buzzard.

May 6th.-Started for the Buzzard's nest at C., going up R. hill. When some way from the nursery containing the nest we were surprised at not seeing the birds about, and on getting closer our surprise turned to alarm. On ascending the tree, which is a Scotch fir, and close to the one in which they nestled last year, I found one egg in fragments and the other with an enormous hole in it-sure work of the Carrion Crow. Both were lying in a pool of yolk and 


\section{$1: 31$}

BIRD LIFE IN WILD WALES

albumen. The egg with the large hole in was an exceptionally small one, and had no marking on it. I have made a specimen of this egg. It now began to hail fearfully, but we continued over the hill to $\mathrm{C}$. nursery, where we found a Crow's nest containing five callow young, three of which the keeper speedily killed. The other brace he left, as he wished to return some evening and destroy the parent birds. Crossing the road, we lunched by an inviting stream on the way to the "Wheel," and watched a Buzzard for some time. Just here, too, the Colonel climbed up to a Crow's old nest, and myself to a Magpie's, but neither contained anything. Crossing a good Snipe bog, we came in sight of a natural amphitheatre, formed by some rocks, where the Buzzards nested last year, and I believe brought off their brood in safety. Soon the Buzzards themselves were on view, wheeling above us, mewing the while. The old nest, which was at the base of a thorn-bush leaning over the abyss, and some fifty feet down, had been patched up, and contained one splendidly marked egg. The nest was lined principally with mountain grass and a little fern.

From here we crossed T. hill, where there is a fairsized cairn, which we added to, and then followed the course of a ravine, where another pair of Buzzards nested last year; but in vain, for they were roobed. Nothing had been done to this nest, nor were the birds to be seen. Passing through a hillside wood, we soon reached another valley, just at the confluence of two rivers. At F. a fairly fresh Buzzard's eyrie was found. No birds were seen, however, and per- 
sonally I do not think that it will come to anything. In an oak hanging over the stream was a Crow's nest of large size, containing five eggs, one of which was addle. The Kite always used to breed here some years ago, but does so no longer, I regret to say. The scenery is simply lovely here, and it was with reluctance that we wended our way homewards. Coming down by the D. rocks we were fairly spellbound and delighted to see a Fork-tailed Kite; we had a grand view of him as he circled above us for a short while and then, gliding over the crest of R. hill, was lost in the horizon. As it had allowed of so near an approach, we thought that a clump of trees on our left might contain the nest, especially as it used formerly to be a favourite breeding haunt of this species; but though we examined several large nests there, we fell in with no luck, so we came to the conclusion that a dead sheep lying there had attracted his Kiteship. The keeper thinks that he saw a Kite just here about a fortnight ago. I should add that we found a Ring Ouzel's nest in a dingle close to the Snipe bog mentioned, containing a couple of eggs.

May 7 th. - Started up the river G. At the Stallion's Pool we found the usual Dipper's nest, and I noticed that the nest they had last year is in use again. It contained four eggs. Further up stream, on a ledge of the bank, found a Ring Ouzel's home with four exceptionally marked eggs in it, whilst we were searching for a Grey Wagtail's home.

We lunched in a dingle, where a pair of Buzzards nested a few years ago, and here found another Ring Ouzel's nest with four eggs and a Ring Dove's, built 
on a ledge of rock-an unusual site - with the usual two eggs.

Thence to the G. falls where the Buzzards were nesting. There were two eyries here, as is usual, but strangely enough each contained an egg. The one in the nest furthest up the rocks was incubated to some extent, but the other was lying in a regular pool of rain water, and was much discoloured. I brought this egg up to the eyrie in use, in hopes that it might come to something. Both these eggs were without markings. The female here is an exceedingly large light-coloured bird, the male a distinctly small darkcoloured fellow. We had a fine view of them both as they circled above the valley.

Crossing the moor, we reached and examined $R$. nursery, and our first find was a Mag.'s nest with a single egg in it. On the border of this plantation we saw a brace of Grey Hens which must have nests somewhere close, and they obviously (or the black cock himself) have been roosting in this nursery, for there were innumerable droppings on the branches of and under several trees. IVe now worked along the L. rocks close by, finding several Jackdaws' nests with eggss, and three Kestrels' scratchings, but none of these contained eggs. There are two young Ravens in the nest here, which Pike pictured in March; and here was exemplified a point in the Raven's nesting economy on which I was by no means certain, viz., that she does not always lay her eggs on successive days, as the rest of the Crow family do, but follows the example of the Hawk tribe in laying only every other day. Now there was only one egs 
in this nest on March ISth and I9th, so clearly another must have been laid after these dates. Secondly, the Raven assuredly begins to "set" after the first egg is laid, and here we noticed that one of the young birds was decidedly larger than his fellow. After a good look at this promising couple and the old Ravens, who were very angry at our intrusion, we made for home, and going through $T$. nursery found another Magpie's nest in a fir, containing four eggs.

May 8th.-I examined the Wolf's Leap for a Grey Wagtail's nest, but met with no luck. Then up the "Devil's Staircase" and across the moor to N., where we soon saw three Buzzards in the air together. One flew towards us, uttering a screeching croak, not at all like the usual mewing cry. After cxamining some rocks up the $\mathrm{T}$., we turned down stream, eventually reaching the dingle where Pike and I pictured a Raven's nest on March I7th. These Ravens now have young, of course. Whilst examining this gorge for a Buzzard's eyrie my companion stayed at the top of the cliff, and shortly I saw him beckoning to me. On reaching him I saw a Buzzard in the air which had flapped out of a little gorge facing us and running parallel with the one containing the Raven's nest. Just after this we made out the nest, which was built in a ridiculously easy place, and contained one very plain egg. Here, too, we noticed a pair of Magpies building their home in a thorn-bush only about five feet from terra firma. Oddly enough, they were getting material from their last year's nest, which was built in another thorn-bush a few yards 
away. Eventually we reached F., where I examined the Buzzard's eyrie that we found a day or two ago. No further progress had been made with it, and it certainly seems deserted. Just after this we reached B., where, climbing a very steep cliff, we crossed the moorland to the $\mathrm{D}$. valley. Descending an extremely treacherous hillside, we got into this valley where it joins another. Just here, in a large wood, a Kite's nest had been reported to the keeper, but we saw no Kites or nest either. I climbed up to a Magpie's nest containing six eggs. Part of the lining in this nest was dried grass, which is decidedly unusual. Charles Dixon, indeed, in his work on "British Birds' Nests and Eggs," states that this material is never used as far as British Magpies are concerned, but here is an instance of how unsafe it is to generalise. Close to L. house we noticed a pair of Stonechats, which seemed sorely agitated, but we had no time to hunt for their secret.

May 9th.-We all started for the Stonechats' haunt. By the stream we hunted, but in vain, for a Sandpiper's nest, though we did find one good scratching. We then visited a keeper who had told us the previous evening that he had set a trap for a Buzzard by a dead sheep. We were all delighted to hear that he had not caught it, but he had captured a dog whose brains the rascal had blown out, for which we sincerely hoped that he would meet with a warm reception from the neighbouring farmers. He further informed us that a pair of Buzzards had made attempts on his goslings; but this savours of the Kite rather than the Buzzard. Visiting the chats, 


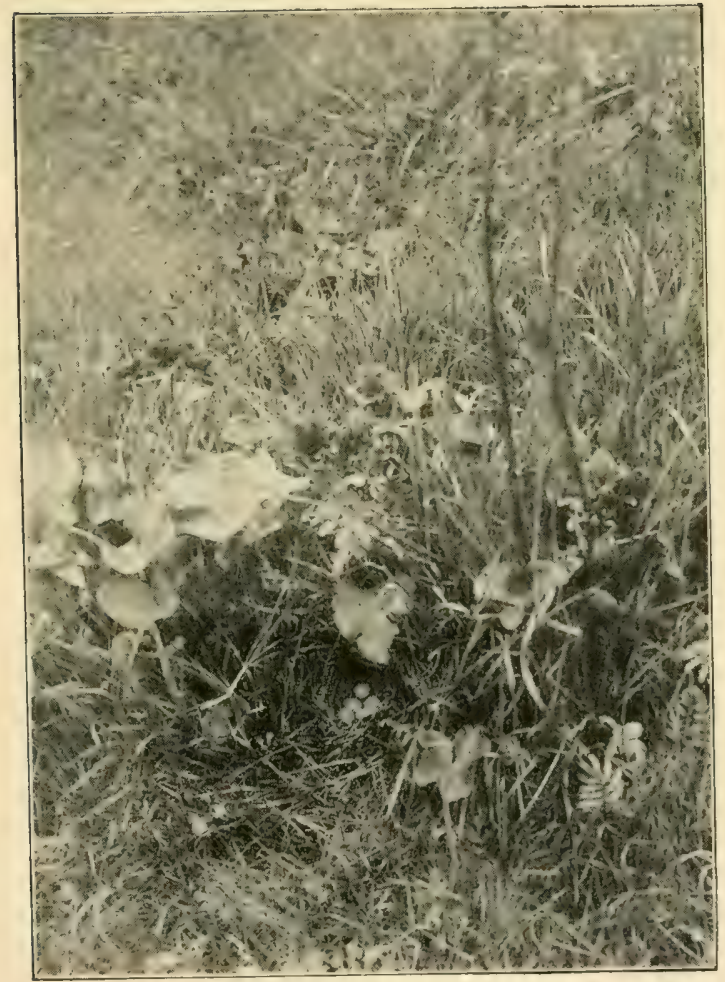

STONECHAT'S NEST. 

we found both birds exceedingly agitated on our approach. We had a great search, which was fruitless, after which we resorted to watching the birds from a distance, and eventually descending from our coign of vantage, the keeper found a nestling quite fledged and out of the nest. Close by, a Wheatear had an unfinished nest under a pile of stones, relics of an old cottage wall. From an adjacent bank a Rock Ouzel's nest had been pulled out by some goodfor-nothing. From here we journeyed to the "Wheel," where, down a disused shaft, was another Rock Ouzel's home. To examine this I had to lean down the shaft whilst the keeper held me by the heels. From here we journeyed to the Buzzard's eyrie close bythe one which held a single egg on May 6th. I got within about twenty yards of the sitting bird before she glided off, giving me a splendid view. Another egg had been laid, which was even better marked than the first. Both these eggs were remarkable for their size and colouring. It is unusual to find size and good colouring in eggs, for usually if well-coloured they are small, whereas if large the markings are not so bright or extensive. Whilst here, a Grey Hen flew across the valley below; they are rather scarce in these hills.

We now crossed back to a dingle above L. house, where yet another pair of Buzzards nested last year. The old nest had been patched up and a fresh one built the other side of the gorge. Here, too, we found another Moor Ouzel's nest with four eggs. It now began to rain in torrents and continued to do so. On the way home we again fell in with our friend of 
the morning, and he graciously informed us that he would not shoot a Raven, but would shoot a Kite if he saw one, and get it stuffed. We sincerely hoped that he would not see a Kite.

May Ioth.-I first visited the New House larch wood, which holds a Sparrow-hawk's nest, finding on the way a Blackcap's with a brace of eggs in it. On getting to the wood I climbed an oak-tree adjacent to the larch containing the Hawk's nest, and noted that two well-marked eggs had been laid. Then on to the Black Bog, where I noted the usual Curlew and Peewit, besides flushing a Meadow Pipit from her five eggs in the rough, tussocky grass. By a little rivulet, bordered by a few clumps of rushes and cotton grass, I disturbed a pair of Snipe, from which I presume that they have not laid yet. The male immediately, on being flushed, began to "bleat." Further on still, in another bog, I flushed a single bird of this species, but could find no nest. From here I made tracks for the "Marten-cat's" rocks; but although I saw both Kestrels, could not find their eyrie, though I knew that it must be there somewhere.

May I I th. - Went out for a stroll by the river and noticed a pair of Pied Flycatchers building their nest in the hole of an apple-tree. The female was doing all the work, and I watched her for some time. The cock bird sang continuously from a branch of the same tree. I noticed, too, that a pair of Hedge Sparrows have just hatched a brood in an ivied stump on the embankment. Almost immediately after this, on getting through some wire into a little 
belt of woodland, I disturbed a Sandpiper from her four eggs, which were exceptionally well coloured. Close here, too, a Blue Tit was nesting in the masonry of a culvert. For some time I watched a gaunt Fisher Heron standing mid-stream in some shallows with great pleasure, and during my vigil he caught one fish. Saw no Kingfishers.

May I 2 th.-Walking along the railway found a Summer Snipe's nest with the usual four eggs. There was hardly any nest-just a few wisps of dried grass. The one I found yesterday was more compact, and, besides a fair quantity of grass, contained some dead leaves.

Found a f́resily cut Green Woodpecker's nest-hole, which I expect contained eggs, but we did not cut it out. The note of the Greater Spotted Woodpecter was also heard just here. We were also very close to a Wood Wren's nest, as both the birds were uttering their plaintive alarm note of "tui, tui," but we could not find out their secret. In the chink of an oak, too, was a Creeper's home-empty, but underneath the tree were fragments of egg, clearly belonging to this species. Previously to all this we had examined a Moorhen's nest, built on a fallen treetrunk lying in a small pond. From what I have observed from time to time, I should say that this species sometimes begins to "set" as soon as the first egg is laid. A Long-tailed Tit's nest containing young next claimed our attention, and then, crossing the road, we made for "The Three Trees," but saw no Woodlarks there, as I expected. Then on to the Black Bog, where the usual Curlews and Peewits 


\section{BIRD LIFE IN WILD WALES}

were cll ciddence; but we did not stop here long, but continued our route to a bracken stack made on the edge of a largish tract of marshy ground. Here we hoped to find a Snipe's nest, but we were not in luck, though we certainly flushed one bird of this species; and there may have been a sitting bird somewhere to hand; but unless one almost treads on a brooding Snipe it is a hundred to one against finding the nest. Continuing along the moor, we followed the course of a rough stone wall, where a pair of Wheatears evinced considerable anxiety, and no doubt they had a nest of young close by ; but to find it we should have been obliged to pull many yards of wall down. We also flushed another Snipe, but again were unsuccessful in our endeavours to find its home. Both the above-mentioned Snipe got up several yards in front of us, and so we knew that they had not risen from their eggs, for this species "sits" till almost trodden on. In this last bog we dropped across four young Peewits just hatched-funny little fellows.

We returned by the Black Bog and heard a Snipe "bleating" there. This bog is a very treacherous and deep one; it has small islands scattered about on it, but these are next to impossible to reach. A few years ago a pair of Teal bred here, but were, I believe, disturbed, and so never brought a brood off. The Blackcap's nest which I found a few days back now contains four eggs of the ordinary type. The Willow Wrens which I noticed building at the end of last month have seven eggs.

May I 3 th.-I punted myself across the river and made straight for a large larch plantation on the $\mathrm{E}$. 


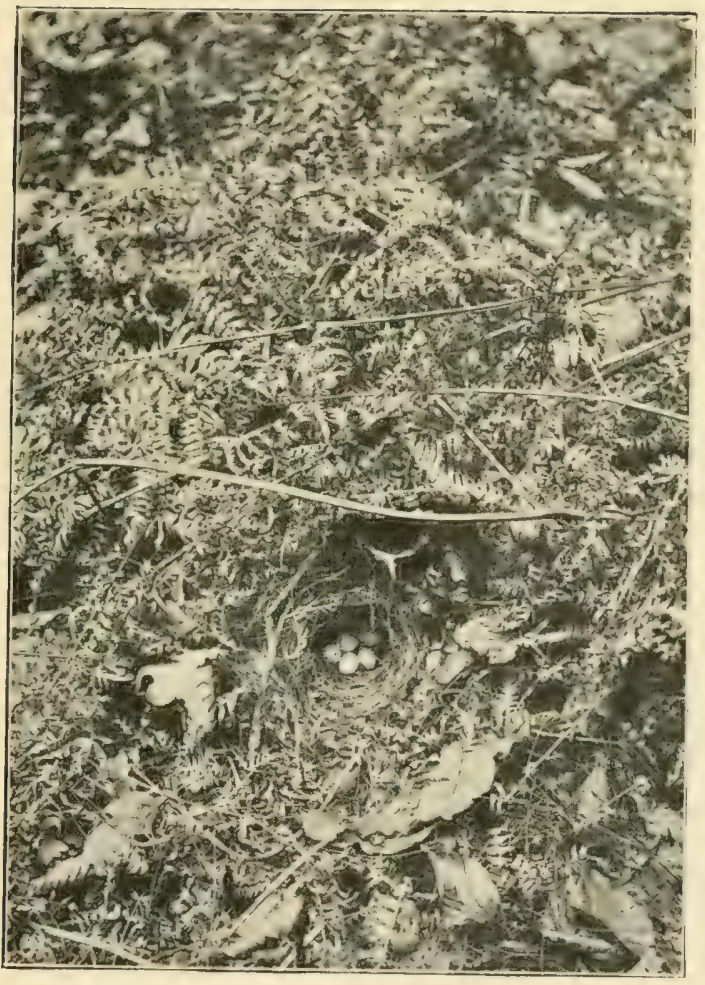

IVOOD WREN'S NEST. 



\section{WITH THE BIRDS IN WALES 147}

hills. On the way up, which was all hill work, I disturbed a pair of Wood Wrens, and eventually found their unfinished nest, which was built amongst dead leaves in a little strip of woodland. Apart from any other consideration, a IVood Wren's nest may be told by the lining, which is composed of dried grass and horsehair in small quantities, though I have seen this latter material absent altogether. It neicr has feathers, as its congeners the IVillow IVren and Chiffchaff always have.

A little higher up this wooded glen I drove a Green IVoodpecker from her nest-hole by smartly tapping the tree containing her. I first discovered this nest by seeing innumerable chips under the tree. I do not think, indeed, that IVoodpeckers ever remove the chips, no such case having come under my own observation; but when any of the Tit family cut out or enlarge a hole in any way they always remove the tell-tale pieces to some distance. Further, you may be quite certain that the tree a Woodpecker chooses is rotten inside, even if outwardly it shows no sign of decay; and in the case of the nest found to-day the bird had to chisel its way through some three inches of sound wood, which must have been an arduous undertaking. On the other hand, I have found nest-holes of these species in such rotten wood that it could be torn away with the hand. Whilst examining the nest in question I heard the wellknown cry of a Pied Flycatcher, and looking round, perceived a male bird sitting on a bough close to me. He looked simply charming as he sat on that alder branch surveying me critically. I could not find his 
nest, however, but in my search for it did discover a Creeper sitting on five eggs, which were on the point of hatching, as was obvious by the dark look of them. This nest was in the usual crevice where the bark had peeled on a rotten stump. I was now close under the larch plantation, so, getting through the wire bordering it, proceeded to search for a Hawk's nest. I disturbed many Ring Doves, and there were old and new nests of this species on all sides, as well as squirrels' "dreys." In the New Forest I also saw one Jay's nest up a fair-sized larch--a somewhat unusual site, though I had seen it before in Hampshire in the good old Winchester days. The bird was on the nest, and did not leave until I shook the tree violently. The usual site for a Jay's nest, I have found, is either a thorn-or hazel-bush; and if honeysuckle is matted over the tree so much the more the bird fancies it. I remember, too, seeing a nest in Kent built at the top of a tall ash sapling-a mere pole, which nearly bent double with my weight when climbing it. I did not find a Sparrow-hawk's nest here, as I expected, though I just caught a glimpse of a male as he glided out of a fir into greater seclusion. I also noticed and watched for some time a pair of Pied Flycatchers, but though they must have had an unfinished or even a finished nest close by, they would not reveal their secret. I now followed the hillside to another hanging wood of great extent close to a quarry. This wood is remarkably difficult to get through, having much underwood and being on a very steep) incline. Here, by the merest chance (for I simply took a line through the covert), I found a Sparrow- 


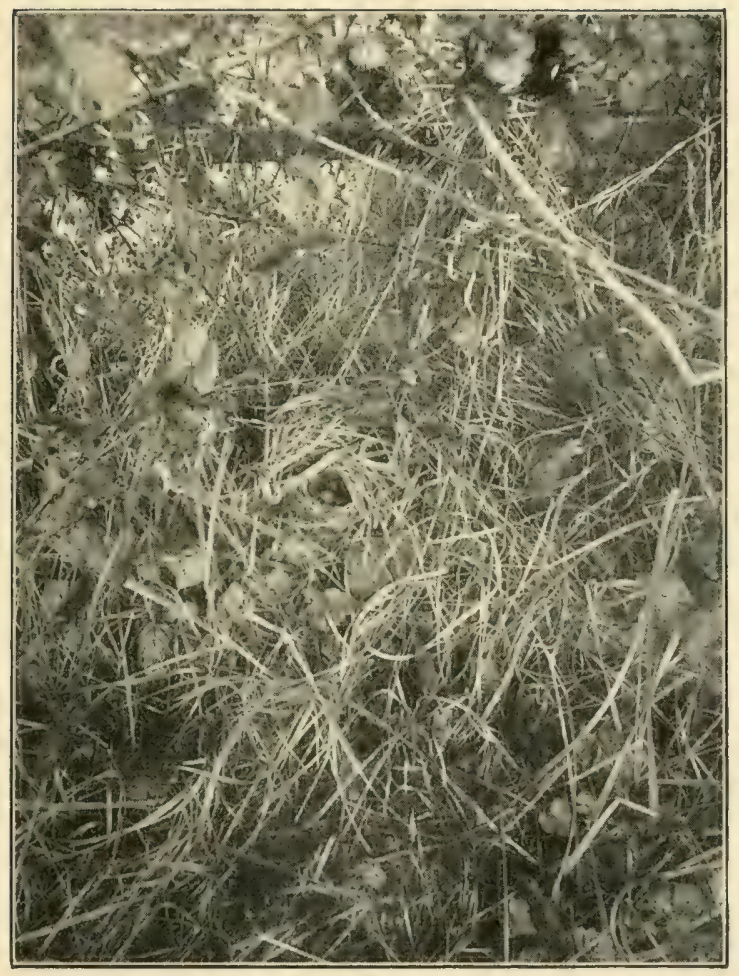

CHIFF-CHAFF'S NEST. 

hawk's habitation, but only half built. This will be a late brood, for down south most Sparrow-hawks are beginning to "set"; but they all seem to be later here. Eventually 1 got down to the river, which I followed half-way to E., seeing many Sandpipers and a fair sprinkling of Grey and Pied Wagtails. Coming back by the road I saw a Wren's nest built in the niche of an ivy-covered rock which contained two eggs. Just here, too, a Grey Wagtail seemed somewhat upset, for he kept flying from the road, where he was running about, to a sycamore hard by, uttering his alarm note the while; but I could not find a nest. Getting to the river again, I had a splendid view of a male Sparrow-hawk catching a Sandpiper, which he bore off to the wood, where I found the nest this morning.

In a little orchard close by I found a Missel Thrush's nest with two young just hatched and three eggs on the point of hatching. The site was unusual, for the nest was only just over three feet from the ground in the cleft of an apple-tree; whereas this Thrush nearly always builds from fifteen to twenty feet up, often more. The number of eggs was also extrordinary, as I have never seen more than four previous to this, whilst Charles Dixon, in his "Nest. and Eggs of British Birds," says that this number is never exceeded, which again show's how unsafe it is to generalise. I watched both birds return to the nest, so there can be no doubt on the point, though the only other nest it might have been was a Blackbird's; but then the unhatched eggs put this out of the question apart from the view I obtained 


\section{BIRD LIFE IN WILD WALES}

of the parents, not to mention their cries of alarm.

May I 4th.-Climbing along the A. rocks, I disturbed many Daws from their nests, as well as Stock Doves and a pair of Kestrels, but I failed to find the eggs of these last, though I must have been very close to them.

Walked home along the river bank and watched a pair of Pied Flycatchers by the ferry for some time. Just here, too, in a thorn-bush, I noticed a Chaffinch's nest containing half a dozen very pale eggs. Later on went up to New House wood, and scaling the tree adjoining the one containing the Sparrow-hawk's nest, saw that two more eggs had been laid. The smaller species of Hawks only lay every other day, and sometimes only every third day. It was quite late when I returned, and the Nightjars were very lively.

Mary I $5 t h$. - IValked into B. by the line and noticed numbers of Swallows perched on the telegraph wires. A great many Swifts, too, were hawking close over the metals. Stopping suddenly to watch them, I disturbed a Tree Pipit from her eggs--six in number. This bird would never have risen had I not stopped point-blank, as the nest was low down in the embankment on my left, and doubtless my stopping made her think that I had seen her. I have often noticed this trait before in birds which "set" closely. You may" walk quickly past a brooding Fern Owl, say, almost treading on her, and she will never move; but if you proceed slowly, stopping occasionally, she will just as certainly rise. Indeed, this is one of the chief points 


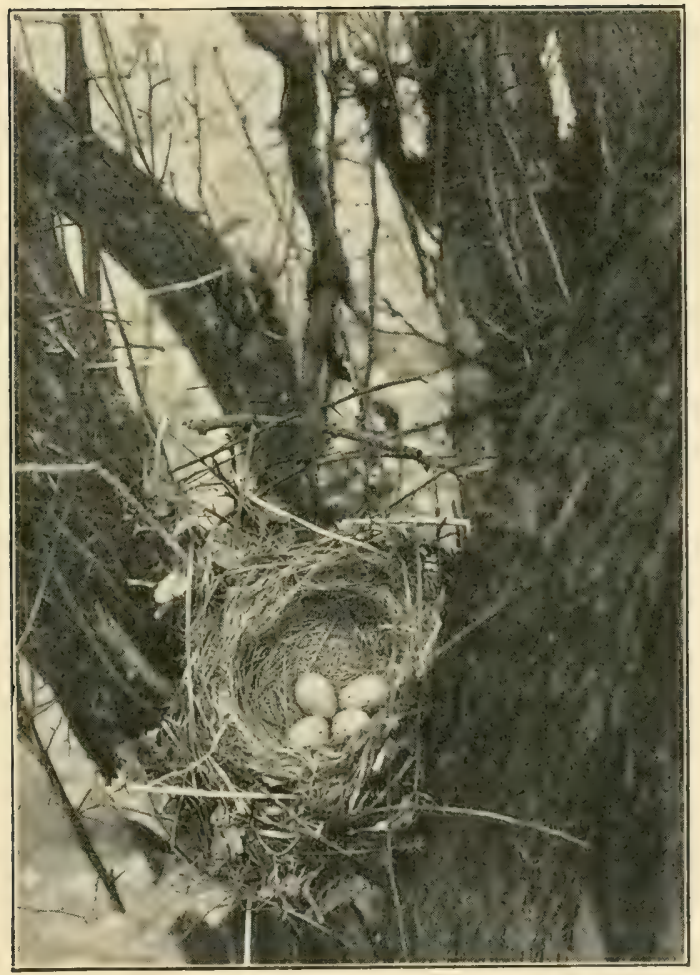

NEST OF MISSEL THRUSH. 



\section{WITH THE BIRDS IN WALES 155}

to be observed in nest-hunting. But to proceed. These six eggs were curious varieties, more resembling a Reed Bunting's egg than anything else.

Going on to L. wood, I found that the Grey Wagtails had hatched out three young, which were about four days old, there also being an unhatched egg in the nest. The Dipper had laid a second clutch of

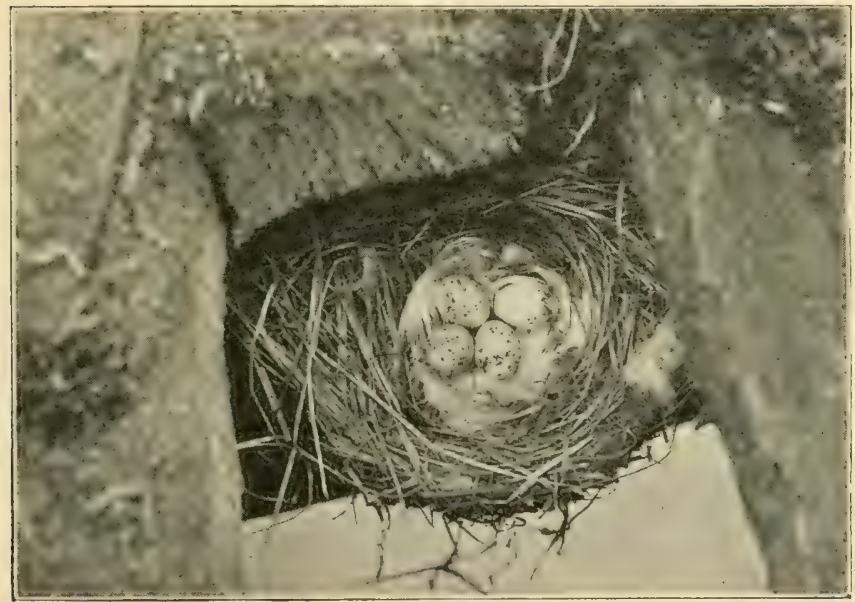

SIVALI.OW'S NEST.

eggs in the same nest, five in number, and had just begun to "set"; for she darted out when I put my hand into the nest. The old lining of leaves had been removed and a fresh lot substituted. Then I made for the wood this side of the Heron wood, where one of the Buzzard's nests is. Some one had clearly been up the tree since I was here last, for there were marks of climbing irons on the trunk, 
which I had not used. The nest, as I expected, was empty, but I heard the Buzzards whistling somewhere about the wood.

On entering the Heron wood I saw a Magpie fly from her nest in a small oak, and on climbing up I found seven eggs in it. The other Buzzard's eyrie here is also eggless, so certainly some one has had them. Just after descending this tree I was attracted by a male Pied Flycatcher, and in a curiously twisted tree, hollowed down the centre for some distance, I found his nest with one egg in it. What a beautiful blue this species' eggs are, and how fragile! They are, I think, perfectly indistinguishable from those of the Redstart as a rule; but not so the nests, for whereas the latter always, or nearly always, uses feathers in the lining of its home, the former never appears to do so. Most of the nests belonging to Muscicapa atricapilla that I have examined have been very loose and untidy structures of dead leaves and dried grass, sometimes with a little horsehair for lining, but I have often seen them lined solely with the finer grass stems. This Flycatcher is very anxious when its nesting haunt is invaded, and a little patience will generally reveal the secret. Continuing my way through the wood, I soon saw two Owlets looking at me from a very flat Crow's nest in an oak. I almost expected to find that they were long-eared ones, but on getting to the nest I at once saw that they were IVood Oivls. One was much larger than the other. Some of the Herons are now hatched, and I see that a pair of these fine birds have made for themselves a nest on top of the Mag.'s nest on the outskirts of the 


\section{WITH THE BIRDS IN WALES 157}

Heronry. I climbed up to an old Crow's nest-a large one it was too-and found that it had been tenanted last year by some bird of prey, probably the Wood Owls, for there were old bones and matted feathers in it.

Regardless of rain, I proceeded to S. wood to see how the Sparrow-hawks were igetting on there. The

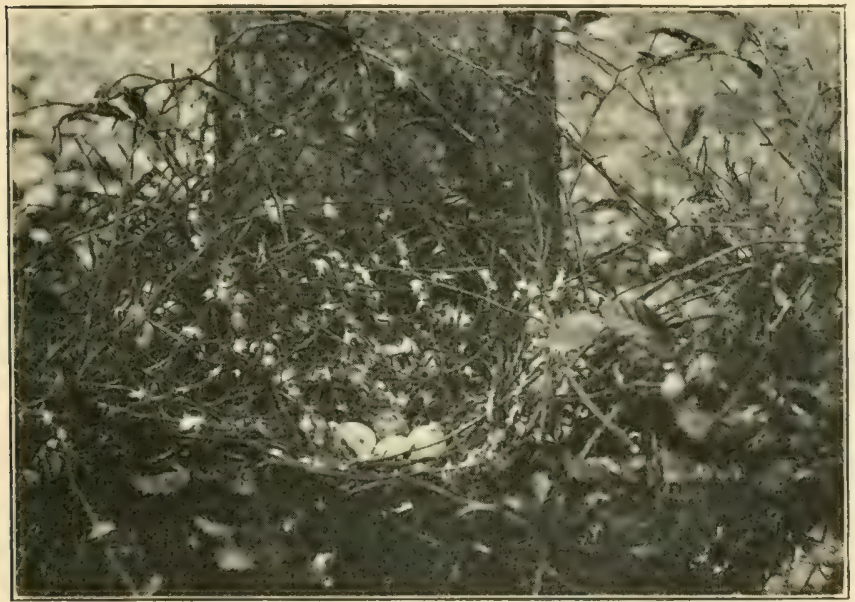

NEST OF SPARROW-HAIVK.

fir wood was full of quiet, a delightful quiet; the resinous smell of the larches had been brought out to perfection by the rain, and the soft velvety moss of the "rides" was saturated with moisture, so that I was enabled to tread even more silently than if it had been dry; for there were brambles hanging at intervals over the beaten track, and what would have been but for the rain, dry, crackling fir-twigs. I experi- 
enced some difficulty in finding the nest again, which was close to a ride (indeed, this Hawk, I have found, evinces a great partiality for a path in its nesting economy). The hen sat on till I shook the tree. This nest contained five eggs, with nothing very special about them except their size. I have frequently noticed, and especially in the Hawk's eggs, that the smaller the egr the richer the colouring. The female, after being flushed, sat in a tree some fifty yards off uttering a note not unlike the Kestrel's alarm cry, but not so shrill or quickly iterated. Occasionally she took short flights from tree to tree, and was much displeased at my intrusion.

May' I 6 th. - Saw the first Butcher Bird that I have seen this year, though surely it has reached these parts ere this. I saw besides a good number of Whinchats and Tree Pipits. Crossing the road, I went down to look at the Missel Thrush's nest in the orchard, and found to my regret that some ne'er-doweel had torn out the whole thing. The Pied Flycatchers have not been ousted by the Great Tits, as I thought, and have, I see, begun to lay. Sat down on the river bank for half an hour or so watching the Sand-martins hawking for insects. I saw nothing of the Kingfishers, but on resuming my stroll discovered another pair of Pied Flycatchers frequenting some oaks and alders by the stream.

In the evening, whilst sauntering through the big larch plantation above my house, I marlied a Sparrowhawk's nest built on top of a squirrel's "drey." It was in a very thin tree-a mere stick-and, as I had no irons, difficult of access. It contained two perfectly. 
magnificent eggs, one of which so resembled a certain type of Kestrel's that had I seen it away from the nest and the other egg I should have mistaken it for one. No description of mine will do this egg adequate justice, and I am sure of its kind it is perfectly unique. The ground colour, where it can be seen, is of a sort of creamy blue; sometimes it looks creamy, at others very pale bluish yellow, and the markings are very intense orange chestnut. The larger half of the egg is hidden entirely by this rich colouring. This is a late lot undoubtedly, but the female may have been delayed by losing her mate, though usually a partner (should any evil befall the existing one) is found within twenty-four hours, as I have proved on several occasions. I noticed numbers of Swifts dashing round my cottage, and some of them should breed there, for there are plenty of holes under the roofing for them. There are no Martins nesting under the eaves either, though I see traces of over tiventy nests, relics of past years. Why they have deserted this house I cannot say, but it seems to me that House-martins and Swallows have grown appreciably scarcer during the past few years.

May 17th.-During a severe shower I sheltered under the tree containing the Crow's nest, by the line. They have young now, but the old birds took care not to approach too closely. The male always seems to be hunting down by the river, as was his custom when his hell was incubating. It now cleared up for a bit, and I continued my ramble on the river side of the embankment, and in a steepish bank flushed a 
Summer Snipe from her nest containing two eggs. In the next hundred yards I put another one up. This nest held four very small and curiously marked eggs, and was wonderfully concealed among bilberry wires; indeed, I spent some time looking for it, as I did not flush the bird under my feet, but some yards off. During my search the hen came back several times, sitting alternately on a fence and the metals, where she ran backwards and forwards in an agitated manner, uttering a curious little note from time to time. Visited the Blaclicap's nest which IV. found the other day; saw the male sitting on four eggs. So closely did he sit that I was almost enabled to stroke him before he took wing. One of the Kingfishers passed me like a lightning flash of orange and azure, and I watched him settle on a bough thanging over the water, and shortly afterwards down he plunged on the slant (a Kingfisher always plunges on the slant) and brought up a small fish, probably a minnow. Close here are the pair of Pied Flycatchers I spoke of a few days back, but again they would not reveal their secret. Continuing my way, however, I examined the nest in the apple-tree and saw that three eggs had been laid. In the same riverside orchard I found a Redstart's home which had been ruthlessly torn out of its site in the cavity of a peartree: and also a Marsh Tit's, containing one egg. I waited for some time in order to identify the species, for it is utterly impossible to tell the egrss of the Coal Marsh and Blue Tits apart unless the parents are watched to the nest. All the Tit family are very wary at the nest, especially the species under notice, 
and many an hour I have waited before they would return to their treasures. There are several pairs of Corncrakes in the meadows adjoining the river; they were "creking " incessantly this morning.

May I Sth. - The nest in the big larch at W., which is obviously a Sparrow-hawk's old nest, appears to have been renovated. A friend showed me a Duck's nest in which a Pheasant had laid, but when we visited it two Ducks were incubating. On a beam in the corner of an outhouse we examined a Redstart's home with five eggs, and in a hole of a thorn-tree a Tit's nest, but of what sort I cannot say, for we did not watch the bird back, and she was not "on " at the time, but we could plainly see eggs. We examined another Pheasant's nest, containing nine eggs, in a very exposed position at the roots of an oak. I hear that the Buzzard's nest on the G. river up in the hills has been robbed. This is one of the few nests where this species hatches off in safety every year, so the news was all the more vexing.

May igth.- Started for A., pursuing the hill range running parallel with the road, visiting en route the Kestrel's haunt, but saw neither of the birds, and beyond finding a Crow's nest in a small hillside oak wood, saw little of note. At the A. rocks I soon saw a pair of Red Hawks over a dingle enclosed by very steep cliffs, but though I viewed the female gliding out of the rocks, I was too far off to determine the precise spot, and unless this species has young or highly incubated eggs it is a very light "sitter," and in no way demonstrative. However, I scaled a certain part of the cliff, and ensconcing myself on a 
convenient and grassy platform, watched the Jackdaws feeding their young for some time. One pair had their nest in a fissure just above me, and the birds ventured into it several times whilst I was there, though with an ordinary walking-stick I could have touched them on every occasion. Going home by the line I saw the cock Butcher Birds perched on the telegraph wires, as is their custom, and visited the Sandpiper's nest which had two eggs the day before yesterday. It now only contains three, so it would seem that occasionally this species only lays three eggs, for Sandpipers certainly lay every day.

In the afternoon visited the Sparrow-hawk's nest in the wood above the $G$. rocks. This nest now contains five eggs. Much down was scattered about ita characteristic of all Sparrow-hawk's nests, though much more obvious in some than in others. The female was "sitting," and did not budge until I had given the tree a few good raps with my stick, when she left, but kept close at hand, uttering from time to time a tremulous scream. I watched her back to the nest, and she was only a fraction over six minutes away. Soon after the male came gliding through the larches with a small bird in his talons, which he deposited by the side of his "sitting" mate. I took the trouble to ascertain what this small bird was, and it turned out to be a Tree Pipit. The farmer here told me that as some friends and himself were standing in his rickyard a day or two ago a Hawk (certainly one of this pair) snatched a half-grown chicken from under their very fect, but dropped it before going far. Returning home, I ascended the 


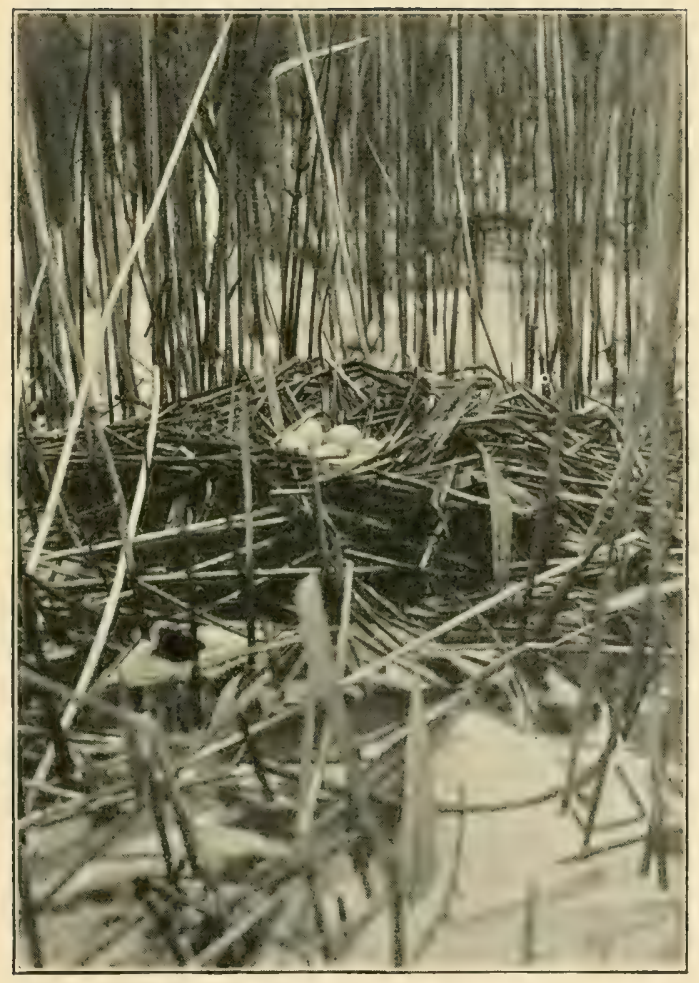

COOT'S NEST.

May 3I, 1902. WVales. 

larch containing the Sparrow-hawk's nest in my own plantation, and found that another egg had been laid, which, though handsome, was nothing very exceptional. In the evening I strolled up the hill where the Wood Wren's nest is; only two eggs had been laid, however. I saw, too, another pair of Pied Flycatchers, and in a very ancient oak found a Creeper's home with nearly fledged young. Creepers are, I think, double-brooded usually, the second clutch of egrgs being laid during the first week in June, the first towards the end of April. This species deserts its nest remarkably easily, that is if it contains fresh eggs, just as the Wren and Blackcap will; but quite the reverse happens should it have incubated eggs or young. I heard and saw some Tawny Owls, one of my special favourites. Did not reach home till nearly midnight. By the way, how I miss the Nightingale here! though in certain parts of this county it may be found very sparingly.

May 20th. - Visited with a friend a sheet of water buried in the hill solitude, called L. pool. I had some waders with me, but unfortunately one of them had a hole in the toe, which rendered them worsc than useless. My friend went after shells chiefly, whilst I investigated the birds of the place. The first find was a Coot's nest with seven eggs, and I waded nearly up to my waist to reach it. Shortly after I was overjoyed by the sight of a Great Crested Grebe floating daintily on the water, and almost immediately after saw the nest, which was very exposed (but there are few reeds here). It was moored to a few tall reeds, and the merest tiro at 
birds'-nesting must have found it. I waded quite up to my waist, and found that it contained but one egg on the point of hatching, as I could hear the young bird chirping inside. Besides this there were fragments of broken egg in the nest, which may have been Mr. Crow's work, as I could not see any tiny Grebes with the old birds, which came very close to me whilst I investigated their home, uttering from time to time a peculiar grating note. I may say that this species begins to sit as soon as the first egs is laid. Proceeding, I flushed several Snipe, but found no nest. Whilst squashing my way through a decidedly damp osier-bed, a hen Reed Bunting went fluttering from her nest, which lay in some matted sword-grass growing up an osier-clump. I almost trod on this nest, which contained five eggs. The female tried all kinds of alluring antics, pretending to have a broken wing and leg, as this species so often will when disturbed at the nest. A little further on, in the reedy undergrowth, I fell in with a nice little brood of seven Pheasant chicks just hatched, with their mother. The halved egg-shells, so neatly packed inside one another, betokened the late nest. I quite feared for their safety in this dank retreat, for there were many pools close by, both deep and muddy-a truly dreadful pitfall for a young Pheasant. Their assiduous mother negotiated them out of these difficulties, and so I left them. After this a Wild Duck dashed from the reeds, fluttering in agitation along the lake, making the water fairly boil. I knew that she must have her ducklings somewhere very close, but I did not find them. Close 


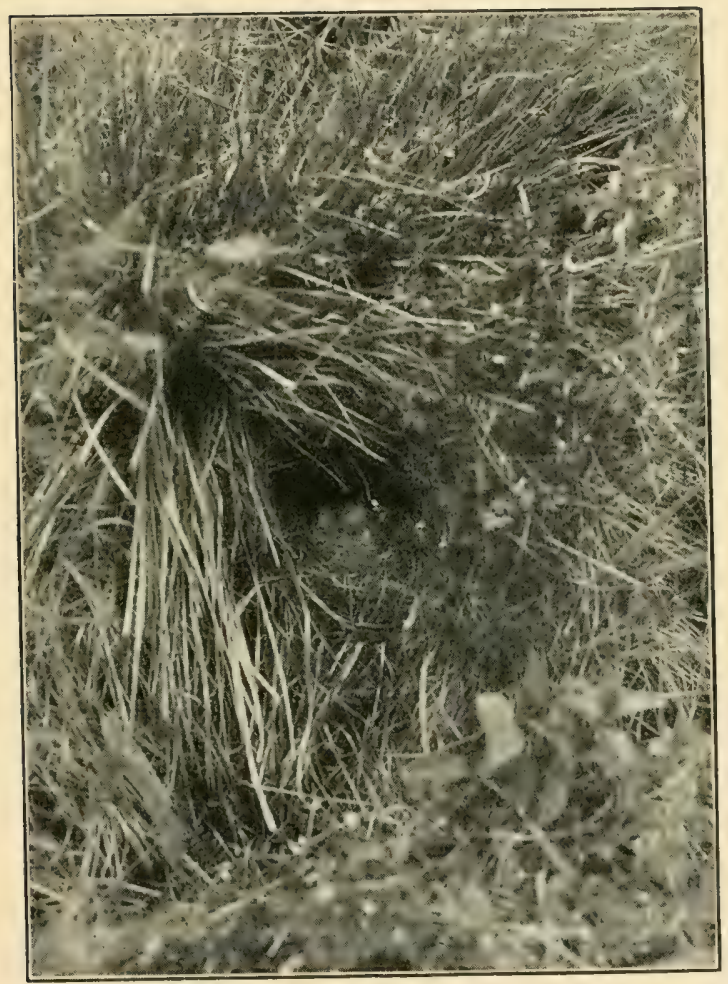

MEADOW PIPIT'S NEST.

June 2, 1902. IVales 

here were two broods of Coot, just hatched, swimming about in company with their parents; and in searching some reeds I found an unfinished Reed Bunting's nest as well as some mock nests belonging to a Moorhen. I may say that I saw no Dabchick or nests of that species either, which struck me as being rather odd.

May 21st.-Went off for L. wood, and on its outskirts found a Pied Flycatcher's nest in a Great Spotted Woodpecker's old nest-hole. One of these latter birds, too, was on the move, uttering its single "chank" of alarm, and as there was another hole underneath the one tenanted by the Flycatchers, I thought that it might possibly be its nest, though it was an old one; but then I have known all three sorts of British Woodpeckers use the same hole two years in succession. The other l'ied Flycatcher's nest in the contorted tree here has been thoroughly looted by something-pulled out and ruthlessly destroyed. I heard the Buzzards somewhere; but did not see them. The Herons were in a flourishing state, and are by this mostly hatched.

Set out over R. hill, and sitting on the brow, from which a perfectly charming view of the river and opposite mountains is obtained, had a capital sight of the male Sparrow-hawk as he dashed by, hotly pursued by an angry Missel Thrush. IValking across the hill, flushed a Meadow Pipit from her five eggs, and I am certain that I was close to a Curlew's nest, but could not find it. - In the morass, where I saw the "bunch" of Golden Plover some three 
weeks ago, sure enough there was one pair of these birds. We only saw one, however, and a fine dance it led us. What a sad note this bird has, though quite in keeping with the mountain solitude! At times this bird settled quite close to us on some little hillock; at others it flew round us in wide circles. After a long and fruitless search we gave up our hunt. The only thing we did find was a Peewit's nest with four addle eggs.

May 22nd.-Through the rain to $\mathrm{L}$. lake in quest of the Crested Grebe. This lake is a fine sheet of water, three-quarters of a mile across, two and a half in length, and between six and seven in circumference. Whilst waiting for a boat I was interested in watching a Yellow Wagtail ( $M$. raii) perched on a stump, uttering its alarm cry. Owing to the heavy downpour the birds on the lake for the most part were skulking in the reeds and equisetums, which in parts of the lake grow very thickly. Just keeping on the outskirts of this reedy bed, we noticed a few Reed Buntings and Reed IVarblers, as well as Coots and a Moorhen or two; but just opposite the church we noticed a pair of Crested Grebes with their one young one, which was about half-grown. This must have been an exceptionally early hatch. I now got out of the boat and did some wading; but beyond a Coot's nest with a solitary egg and a baby Coot just hatched, which we much admired, found nothing. Those left in the boat also found a Coot's nest, but as we had not a proper boat for getting well into the reed-beds we put about and made for the landingstage, where we at once got into conversation with 


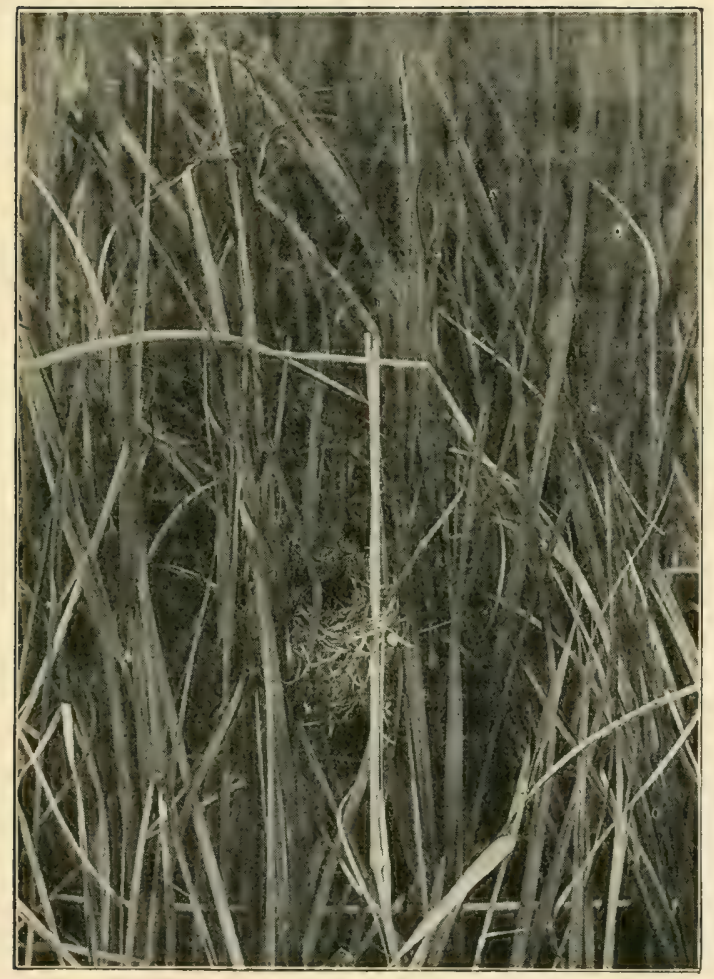

EXTERIOR OF REED WARBLER'S NEST. 

one of the boatmen. He said that there were between fifteen and twenty pairs of Crested Grebe on the lake, but that owing to the rain they were all in the reeds skulking, and about one hundred and fifty pairs of Coots, as well as Moorhens, and a few Wild Duck and Snipe. He further informed us that the Crested Grebe never reared more than two young even out of a clutch of four eggs; but this, to be believed, must be investigated. I Iaving still a couple of hours on hand, we got a narrow little boat, and, piloted by our boatman, set out for some of the chosen haunts of the Grebe. The first place was in rather an isolated clump of reeds, and here we found a Coot's nest, an old Grebe's nest, and the real article containing four eggs. On our approach the old birds had dived, leaving their eggs partially covered with water-lily leaves. In this nest two eggs were partly visible. They do not cover them half as effectively as the Little Grebe or Dabchick, as it is commonly called. Rowing across the lake, we speedily found another nest with three eggs in a reed-bed just opposite the church. These eggs were larger than those in the first clutch-rather in bulk than in lengthand were more incubated, as could plainly be seen by their colour, a dirty brown; for when newly laid all Grebe's eggs are a sort of bluish white, but soon become discoloured from all the parents' feet and the general dirtiness of the nest. Indeed, it is a marvel to me how the eggs ever hatch, for the water literally oozes through the decaying mass of reeds and suchlike matter which constitutes the nest. 


\section{BIRD LIFE IN WILD WALES}

The Vicar showed me a Willow Wren's nest in his garden with four eggs of a distinctly unusual type, with bold blotches on them instead of the usual speckles. A Creeper, whose nest was taken about ten days ago, has built a fresh nest in identically the same spot. This nest is in a pollard willow, behind some peeled bark.

May 23rd--About noon I noticed a pair of Goldfinches fly into a tall sycamore close to the house, with wool in their beaks. I then knew that they were building there, but had not time to locate the nest, which will be no easy matter, for the foliage is well out by this. On the way to the river we found a Long-tailed Tit's nest and a Willow Wren's; the former in a wild rose-bush, the latter in a small bank. Then off in search of the Golden Plover's home. On our arrival we saw both the old birds, but again they foiled us. They were further along the bog than on our last visit. One of the birds, probably the female, flew right away; but the other one endeavoured to draw us from the spot with divers alluring antics. On the way home we found a Carrion Crow's nest, built in an ash-tree growing down a small ravine, containing four young, which I promptly killed.

May 24th.-Started for L. wood. The young Grey Wagtails under the railway bridge have flown. I located two more pairs of Pied Flycatchers in the wood, and watched the Ilerons feeding their young for some time. One beautiful male Heron came into the tree under which I was standing, affording me a remarkably fine view. One has to keep well hidden and very quiet in order to watch these huge grey 


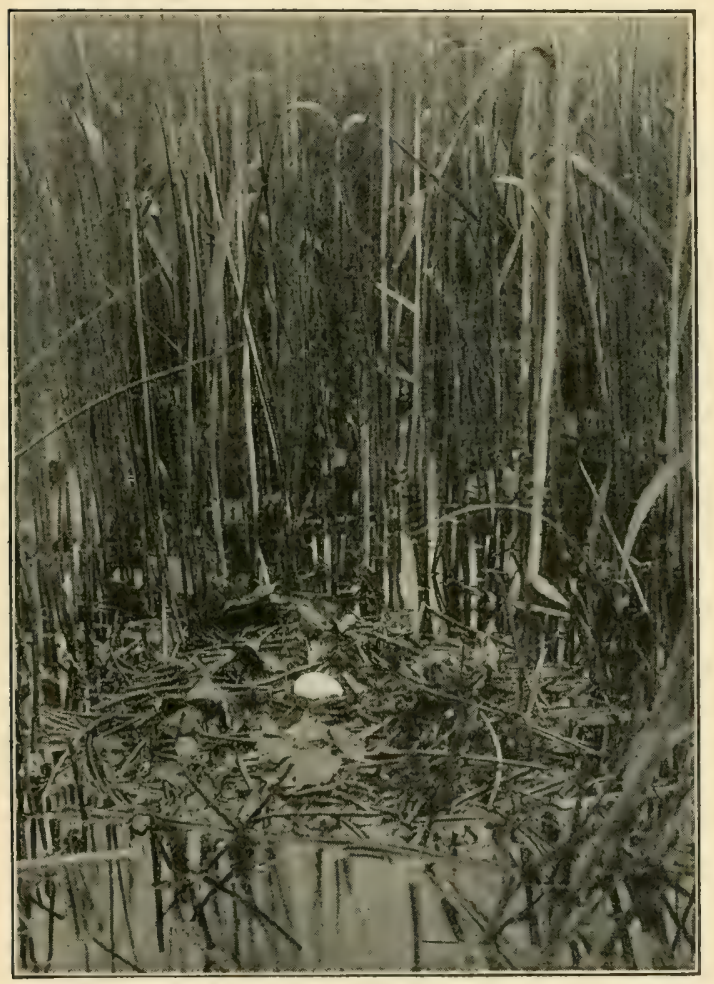

NEST OF GREAT CRESTED GREBE, UNCOVERED. May 3 r, 1902. Wales. 

birds feeding their young; for they are excessively shy, and will not approach their nests should they suspect danger. From time to time they uttered guttural notes, expressive of alarm, and the young Herons responded with very peculiar sounds impossible to describe. After an hour or two of this, I went into the smaller wood adjacent, where I saw both the Buzzards, which were clearly agitated; but I could find no eyrie in use. Buzzards will sometimes (should any mischance befall the first clutch) lay again, and if they do a fresh nest is generally built. In this wood I found a fresh cutting of the Great Spotted Woodpecker's, which I think is tenanted, as I saw one of the birds close by.

Again to the Golden Plover's haunt. We found one bird in the same spot as yesterday; but though we tried to circumvent the Plover by going away for half an hour and then creeping up over the brow of the hill, we were unsuccessful. This ruse we tried twice, and the second time located a pair of Snipe, flushing both the birds, but not from the nest. ${ }^{\mathrm{I}}$ We had a fine view of the male flying in circles, "bleating" the while, as is his wont during the season of reproduction. This sound is a very curious one, and is, I think, caused by the tail. I notice that it always occurs when the bird is flying downwards; but no one has yet, so far as I know, discovered the exact source of the sound. Whilst looking for the Golden Plover's nest we found a Peewit's, containing three eggs.

"I have once or twice heard a Snipe "bleat" when at rest; which would seem to dismiss the tail theory. 
Mary 25th.-Sitting in the garden in the morning, I saw a Buzzard pass over at a great height, on his way, I imagine, to S. wood. When just over the house he made a few sweeping circles, soaring beautifully, and then continued his way. I also watched the Goldfinches building, and, climbing the sycamore, located the nest. It is right at the summit of the tree, and, as is usual, at the end of a branch. Indeed, you will seldom find this finch's charming home in any other situation, though occasionally I have seen one in the crotch of a fruit-tree, but sycamores and horse-chestnuts are great favourites. I noticed that the Pipit's nest in the embankment has two eggs, rather curious ones, and if a Tree Pipit's, a very greyish brown variety - a colour which is unusual in this species, for thourh the egers differ considerably (but they are always alike in the same clutch) they nearly always show a tinge of red, unless they are the olivetinted types. Size, however, must be taken into consideration as well; but Meadow Pipits' eggs are almost invariably smaller than those of the species under notice, besides seldom showing any red. The great thing is to identify the birds at the nest.

May 26th.-Off to Tenby, reaching there at 6 p.m. W. V. met me, but we did nothing in the bird line that evening. To-morrow we go to St. Margaret's Island. The Peregrines at Lydstep Head have been robbed, I hear.

May 27th, 28th, 29th.-See the chapter entitled "With the Sea Birds at Tenby."

May 3 Ist.--Pike, his friend, and myself started for L. lake to photograph a nest or two of the Crested 


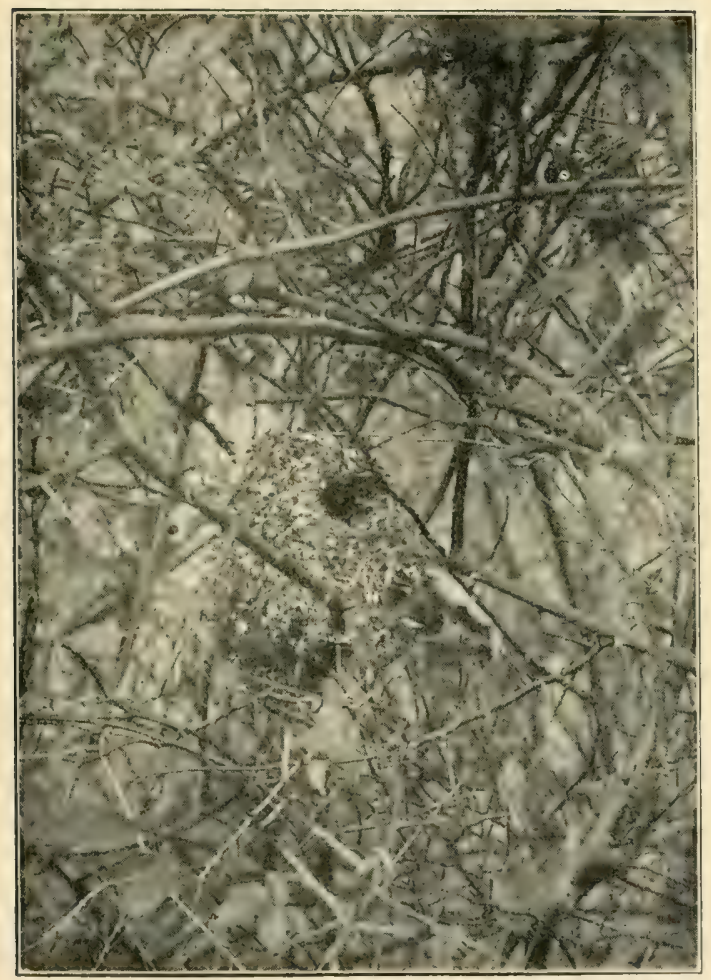

NEST OF LONG-TAILED TIT.

June I, I902, Wales. 

Grebes. We secured a good boat and boatman, and went in search of the Grebes. We were soon busily engaged in picturing a nest with one egg in it; but later on Pike got a splendid series of photos of one containing four. We saw many Grebe on the glassy surface of the lake; for it was a perfect day, and in consequence they were not keeping to the shelter of the reeds. How exceedingly graceful the Crested Grebe is! Watch that male out yonder, some sixty yards from the boat: just now he is preening the satiny white plumage of his breast, which fairly sparkles in the sun. How graceful the profiled outline of his small and finely chiselled head! But see! something has alarmed him, for quick as thought he has dived and will seek the seclusion of some dank nook in the rushes or else reappear further from us.

Landing the church side of the lake, we hunt some swampy ground in search of a Snipe's nest, and find the following: two Peewit's nests, one with three, the other with two eggs, as well as some young of this species. It was a late date for the Green Plover's eggs; but undoubtedly some mishap befell the first or even the second attempt. One set of eggs were very dark, the other exceptionally light varieties. Just after this we discovered a splendidly concealed Whinchat's home with five eggs, and a little further on, in a clump of sedges, a Pheasant's nest and the old home of a Wild Duck. Out in the drier part of the meadow a Yellow Wagtail's nest is presented to view under a marsh marigold, but is not well concealed. There were several pairs of these charm- 
ing Wagtails about; and one pair had young, I know, but we could not find it. All these things Pike pictured, as well as a Coot's and Moorhen's on the lake.

June Ist.-A pair of Nuthatches have occupied the cleft in the ash-tree where the Redstarts were nesting: I say "were" because they were robbed by some farm children. We started operations by photographing this Nuthatch's nest, and then the Goldcrest's in my garden. Journeying riverwards, we depicted a Long-tailed Tit's home, as well as a Marsh Tit's.

After this we walked along the line, photographing on the way the Tree Pipit's nest in the embankment, which now contains six eggs. The following pictures were also made: Bullfinch's, Greenfinch's, Redstart's, Creeper's, Spotted Flycatcher's, and Wren's nests. The first two were in box-bushes in the churchyard; the Redstart's under the slates of an outhouse; the Creeper's in the cleft of a pollard willow under a piece of peeled bark; the Flycatcher's in the cavity of a wall; whilst the Wren's was in a bundle of dried sticks.

June $2 n d$.-To L. wood, to depict the Heronry there, photoing en route a Meadow Pipit's home with five eggs. Found a Tree I'ipit's with a brace of the olive typed eggs. We now reached the archway under the line, where the Dipper and Grey Waytails are. The former we found was sitting on four eggs, and the latter on five. This is the Dipper's third attempt, for the second clutch of eggs was taken, and the Wagtail's second. They were both difficult nests to 


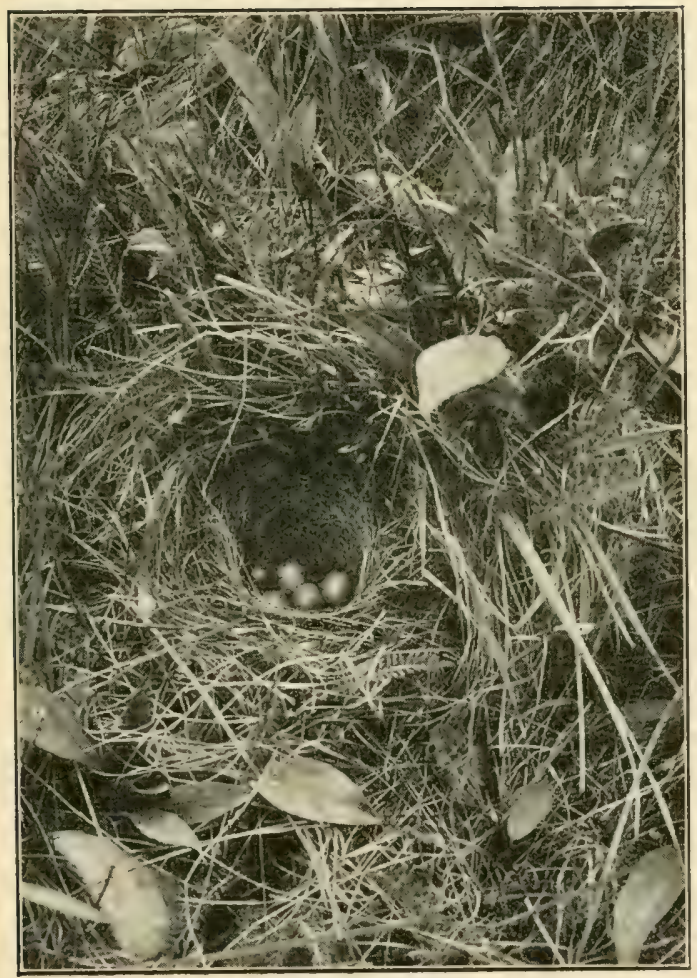

TREE PIPIT'S NEST. 

photograph, owing to the extreme darkness of the archway, especially the Dipper's, and this plate was exposed for many minutes. Entering the smaller of the two woods, we were fortunate in seeing both the Buzzards, but I do not think that they have attempted to lay again, for some one certainly had the first clutch. Then to the Heronry, where five photos were obtained, both of the eggs and young. One clutch of eggs was certainly fairly fresh, and this is a late date, but this is accounted for, I think, by the robbing propensities of the Crows. Here, too, we found a Great Tit's nest with at least nine eggs, and also had a great hunt for a Pied Flycatcher's home.

June 3rd.-Strolled down to the river, but saw no Kingfishers. The Kestrels appear to have deserted the rocks above the cottage, for I never see them there now, nor do I see the pair along the A. road.

In the cool of the evening walked down the $\mathrm{N}$. brook, but could find no traces of a second brood of Grey Wagtails there, for one brood has flown already from this little stream. Coming up the lane towards home, I discovered Chaffinch's and Whitethroat's nests, both with eggs.

June $4^{t h}$. Climbed the sycamore in the corner of the garden and inspected the Goldfinch's nest. It was an exceptionally beautiful example, even for this species' nest: lined plentifully with creamy-white vegetable down. The outside was composed almost entirely of wool, strengtlened with some bents. There were five eggs, and ixcept for being slightly 
smaller, might well (putting the nest aside) have been mistaken for Linnet's.

After this I set out for the C. hills, finding, just as I started, a Yellow Bunting's nest in a wild rosebush. I went up through the G. rocks and New Iouse wood, where the Sparrow-hawks are nesting, and so to the Black Bog. Here the usual Curlews and Peewits were soon seen and heard, and a little further on, by a tiny rivulet, I flushed a pair of Snipe, shortly after finding their nest under a tuft of cotton grass, containing three very beautiful eggs. I could hardly have missed finding this nest, because there was very little rough herbage about, such as Snipe love for nesting purposes; moreover, I had noticed this pair here all through the spring. On through another boggy bit of ground I flushed another brace, but found no nest, though I had a great hunt for it.

At the "Marten-cat" rocks I at last discovered the Kestrel's "nest." Oddly enough, the male was on the nest, and he never left his charges until I was almost on top of him, whilst climbing down the cliffside, which was very precipitous. This eyrie was in a very snug hole in the rock, and contained three young just hatched and two eggs on the point of hatching, which reposed on a plentiful bed of "pellets," ejected, of course, by the parent birds. Although I stopped close by for some time, I saw nothing of the female, so can only presume that she has come to grief, for though both sexes of this species incubate, yet at the present stage of affairs one would have expected to find the female on the 


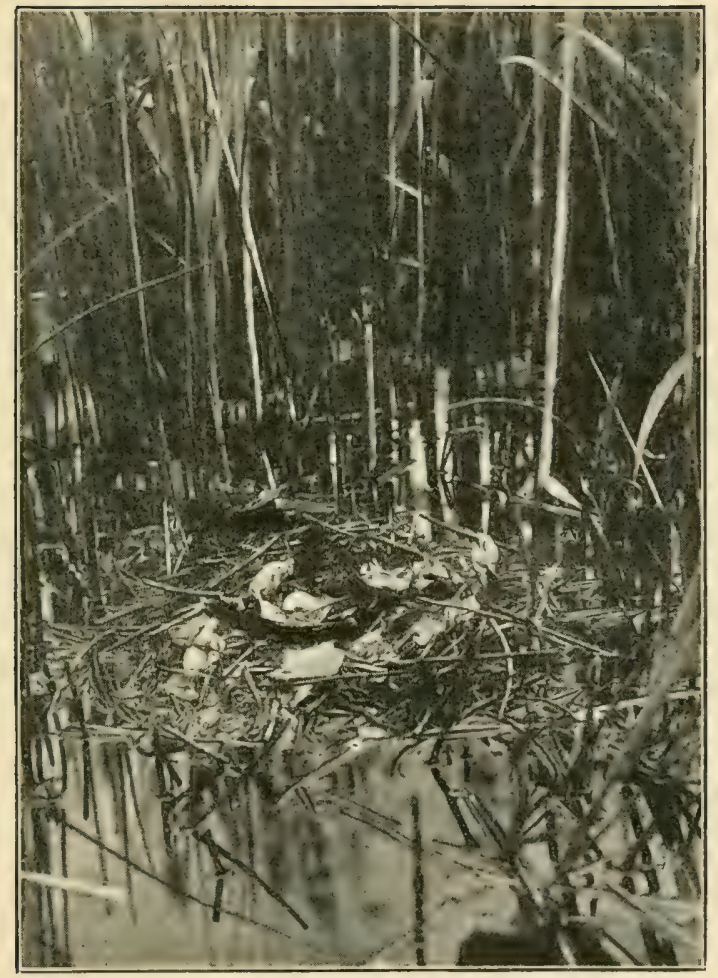

NEST OF GREAT CIKESTED GREBE, COVERED. May 3I, 1002. Wrales. 

nest. I examined many pellets, which proved to contain quantities of mouse fur and bones with the wing-cases of beetles, but no birds of any sort, though on an adjacent ledge I found the remains of a Sparrow. Whilst waiting for a view of the Kestrels I was much interested in the actions of a pair of Magpies, quartering the ground carefully, no doubt for a ravenous brood, and they were certainly looking for some young Curlews, for an adult pair of these last-named birds were in sore distress, at times fairly stooping at the Magpies.

I have learnt a lesson over the Snipe in these parts, for they would appear to be exceptionally late breeders here, as certainly the two pairs that I saw this morning are only just beginning to lay, and the nest I did find only contained three eggs, whereas a Snipe invariably lays four. Now, down south Snipe are often hatched during the first week in May, very occasionally sooner. In Scotland I know that they are very late breeders, but should never have suspected it here in the west. In consequence, I was looking for Snipes' nests in April and during the whole of May, not understanding why I was unsuccessful.

Just by the quarries a Woodlark was singing beautifully, and I saw him, whilst searching some bracken for his nest, but I did not find it. Just here a pair of Kestrels were hawking gracefully as usual.

June 5th-To the hills to see how Pike and his friend had been getting on. The former had been photographing a Curlew's nest on the hill facing the 
inn, with a couple of eggs in it. These eggs, I was told, were much incubated, so no doubt the Crows had been up to mischief. I expect that they had "commandeered" the first attempt as well, for without doubt this was a second laying, and a Curlew seldom, if ever, lays less than four eggs.

I will now recount their doings in the hills. After

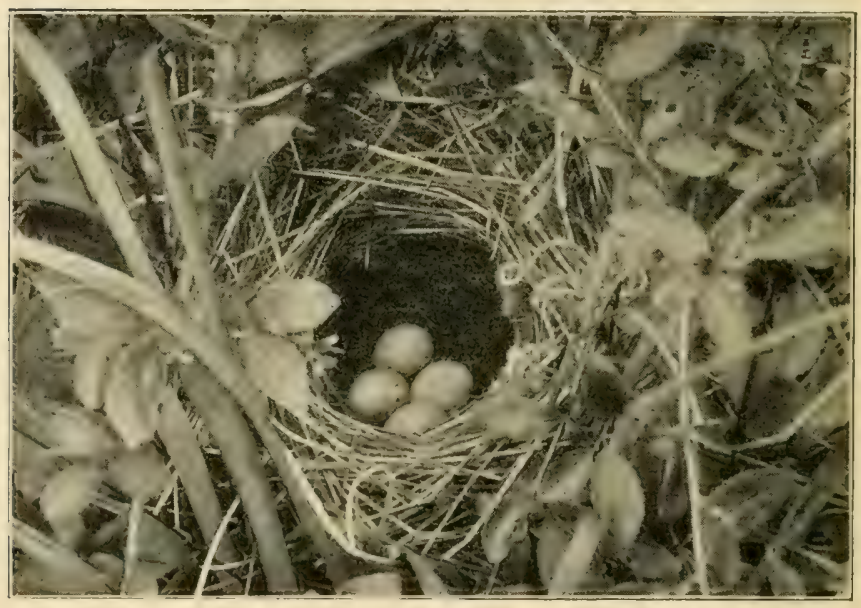

NEST OF IVHITETHROAT.

we left them on the and instant they proceeded along the metals, catching the train easily at G. Immediately on their arrival the keeper took them to a Sandpiper's nest, which they both photoed next morning. They visited the Buzzard's eyrie up the G. stream, finding that the birds had constructed a fresh nest and laid another brace of eggs, very plain ones. Further back in these pages I recorded this 


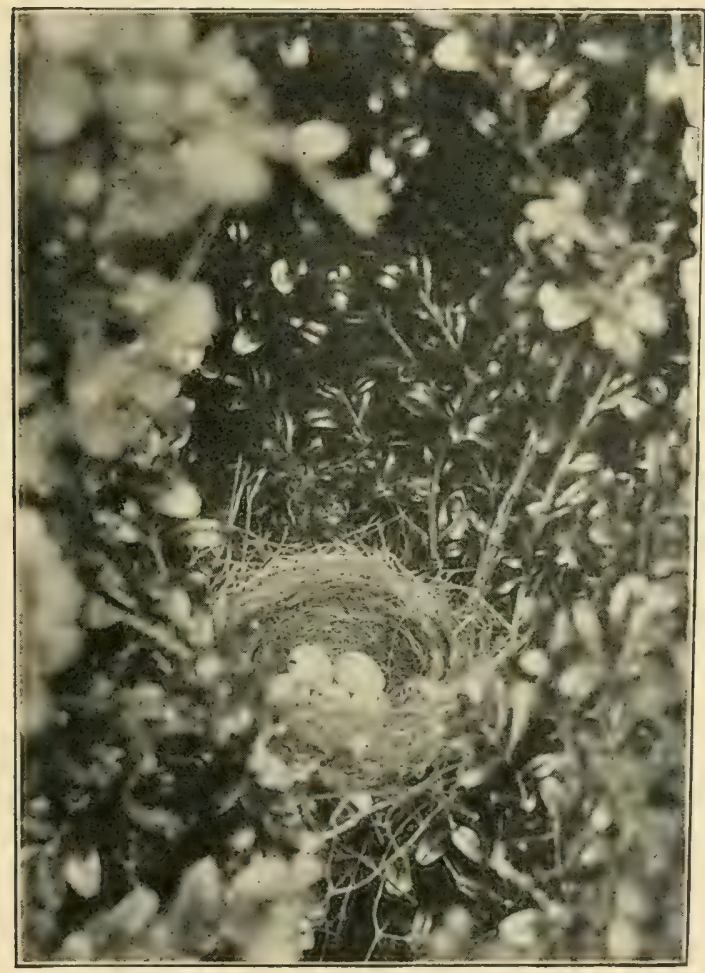

BULLFINCH'S NEST.

June I, I902. IVales. 

nest as having been robbed, as we all thought, by a sheep-dog; but this is by no means certain. Close to this eyrie they found a Grouse's nest with one addle egg and another containing a dead chick. Then, proceeding to the Black Crags, they pictured the Buzzard's nest there, which also had two eggs with no special beauty about them. Further on toward D., quite the highest mountain in these parts, they watched a Golden Plover for some time-two hours, in fact-but could not find the nest.

They reported, apropos of a Kite's nest that they had found built in a little belt of trees, principally oak, that the young Kites had flown, as was clearly indicated by the state of the nest; and further the farmer here had said that they flew last year, which is news indeed. Pike brought some pellets from the nest, as well as a piece of packing-thread about a yard long. This nest was composed of branches and sticks, lined principally with lamb's wool. Last year's nest was in an adjoining tree. The farmer stated that he had seen the old and young Kites together in the air, which must have been a sight worth going miles to see. There can be no doubt, I think, that this pair of Kites is the same which have for many years tried to rear a brood, but unsuccessfully, in a valley some three miles distant; and probably the young that flew last year were the second attempt, for the first clutch of eggs had been taken. The Kites, then, must have shifted quarters for a second venture, and having brought off their brood in safety. thought that the place in cuestion would be far better than the spot where they were continually robbed. 


\section{BIRD LIFE IN WILD WALES}

Hence the two nests; and long may the Kites continue there! But to continue. Examining the D. rock, a Buzzard's eyrie was soon found, containing one nestling about a week old; and in $\mathrm{P}$. wood, in the eyrie which I found well lined with larch shoots on May 5th, were three really well-marked eggs. Indeed, the keeper told me that for a set of three he had never seen better ones, and his opinion is well worth having. They photographed all these good things, as well as a Rock Ouzle's nest in ' $T$. dingle, with two young and a like number of eggs on the point of hatching.

Now to the day's work in question. After breakfasting we all started for the $T$. valley, and on the way, examining a dingle not far from L. House, found a Grey Wagtail sitting on half a dozen eggs. This nest was built on a nice ledge of rock about a yard above the foaming torrent, and I think that the bird might have been photoed on her eggs. Just here, too, I almost put my hand on a Ring Ouzel's back as she sat on her five eggs, which were almost fresh (you may always know a fresh egs by holding it up to the light). A Water Ouzel dashed up the dingle, and I feel sure had his mossy home somewhere close. I saw that the Buzzard's nest there had come to grief, for we found fragments of eggshell in it-another instance of the Crow's robbing propensities, I think. I may say that our chief object to-day was to try and locate a pair of Kites which had been reported to us; but on reaching the spot we saw nothing of them. We hunted through $\mathrm{T}$. woud carefully, but beyond finding a Sandpiper's 


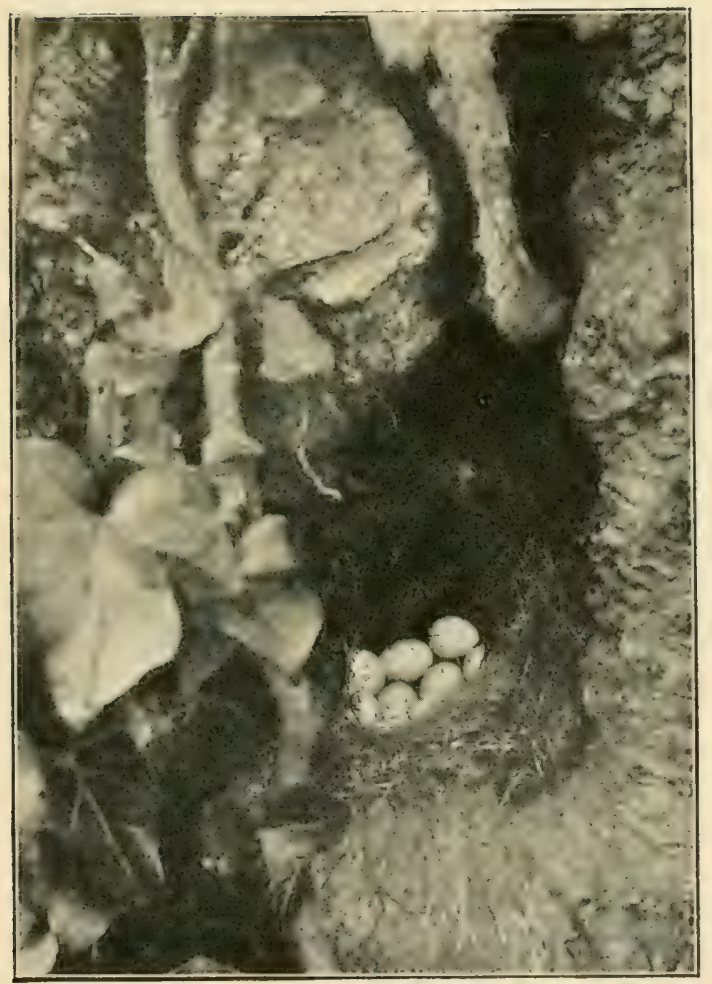

GREAT TIT'S NEST. 

nest on its outskirts, were not rewarded. Other finds in the course of the day were a Yellow Bunting's nest and a young Wheatear, which were both converted into "plates." Further, we were glad to see a nice brood of Ravens on the rocks above their eyrie; and here, too, a pair of Kestrels were greatly distressed, but we did not find their eggs. We saw nothing of the Fork-tailed Kites all day.

June 6th.-Heard a Grasshopper Warbler last evening reeling out its curious notes, so to-day, visiting the spot, endeavoured to find the nest, which was certainly somewhere in a furze covert of no great extent, but we were quite unsuccessful. The Vicar has a Lesser Whitethroat's nest in his garden in a boxbush. This species is by no means plentiful here; indeed, this is only the second pair that I have seen this summer. On the G. rocks I flushed a male Nightjar (always known by the white feathers in the tail and wings, which the female lacks), and in the embankment a Tree Pipit fluttered from her callow young. This spot I had repeatedly passed, and must have almost brushed the sitting bird on many occasions.

June 7th.-Went up over the hill to the Golden Plover's haunt. On reaching there, saw both the old Plovers, many Peewits, and two cock Grouse, which must have hens sitting somewhere close at hand. Grouse lay according to the state of the weather, being governed probably in this respect more than any other bird, and as the present spring has been exceedingly rough and cold, many Grouse will only be laying now ; besides which on this hill, there is 
very little thicli heather, and in consequence, the nests being made in very exposed situations, fall a prey to Crows and suchlike evil-doers. I had another great hunt for the Plover's nest, but once again was baffled, and my search only revealed a couple of Lapwing's habitations, with four and two eggs respectively, the latter set being addle. It hailed abominably and the cold was intense. I heard a Snipe "bleating" somewhere, but could not find his nest. Towards evening, after my return, I wended my way to the line and found a P'ied Wagtail's nest in the same rocks as the Grey Wagtails. Just opposite a farm-house bordering the railvay I watched a male Butcher Bird for a considerable time. At last I saw him catch a beetle, flying on to the metals for it, and take it to a hedge aligning the embankment. I at once knew that he was feeding a sitting mate, for his larder was in a hedge the other side of the line; so proceeding to the spot, I soon flushed the hen from her six eggs, which were of the green type. Three days ago a pair of House-martins started a nest under the eaves of my house, but they do not appear to be making much progress. This is rather a late date for them to start operations, though you will seldom find this species' egs before the last week of May or beginning of June. This Martin's esgss can be readily confused with the Sand-martin's, but they are constantly larger and have a decided gloss, which is absent from those of the latter. Of course at the nest there is no possible chance of confusion.

June Sth.-I see that an accident has happened to 


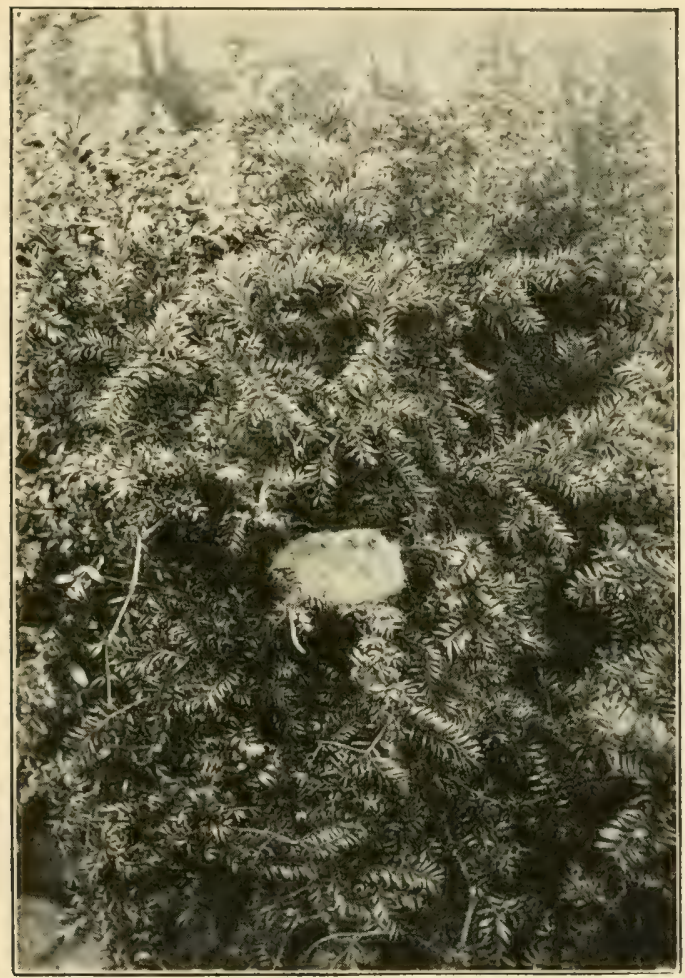

GOLDFINCH S NEST.

May, Igo3. IVales. 

the Bottle 'Tit's nest by the river: some of the eggs are broken. This morning a pair of House Sparrows made a determined onslaught on the Martins under my eaves, and in the evening I found that the former had taken possession.

June 9th - Started once more for the Golden Plover's haunt. On the way, whilst jumping a small stream, I flushed a bird from her nest in the rocky bank, which proved on closer examination to be a Ruck Pipit. I make this statement with all confidence, for I had a close view of both birds, and they had the outermost tail-feathers edged with smoky brown, a sure characteristic of this species. Further, I heard the male's song. I know that this statement will be questioned by most present-day ornithologists, but others have seen Pipits on the Welsh hills which they thought at first were Water Pipits, but afterwards came to the conclusion were Rock Pipits. I myself have seen Pipits from time to time on these hills, which puzzled me not a little, but I think that the mystery is now explained. The eggs in this nest, five in number, were considerably larger than Tree Pipits, and were of a brownish white ground colour, freckled, streaked, and marbled with several shades of reddish olive, some of the darker streaks being almost black.

In the Plover's haunt I again flushed a couple of cock Grouse, but could not find their hens or the Plover's nest. By this time these latter birds must be sitting very hard-indeed, they may have young, judging from their actions.

Coming back through some thickish heather, a 


\section{BIRD LIFE IN WILD WALES}

Curlew rose literally at my feet, quite startling me for the instant. Lying so close as this, I thought at first that she might be wounded, but on looking down saw her nest with two eggs in it. These were almost hatching, but the shell was not "pipped." It is extremely unusual for a Curlew to sit close under any circumstances, for as a rule, the moment their haunt is invaded up they all get clamouring loudly, and this even if incubation be well advanced. Nor could this bird have failed to see me, for I was coming downhill at the time.

After this interesting episode I examined some likely looking heather for a Grouse's nest, but beyond flushing a Snipe and finding a heap of Grouse feathers on a little tump (probably the work of a passing P'eregrine) saw nothing. In the afternoon I found a Wood Wren sitting hard on seven egress, and searched besides for a Fern Owl's nest, or rather eggs I should say, for nest this species has none, simply laying its two marbled eggs on the bare soil, generally under the shelter of a bush or clump of bracken. As evening drew near we wended our way to the G. rocks, where we located two pairs of Fern Owls, or Spinners, as they call this bird in these parts. We saw four in the air together, and noticed the males chasing their hens in the gathering gloom. They made the evening lively with their "jarring," which once heard can never be forgotten, even by a person with no great interest in bird-lore.

June IOth,-During a walk along the railway I watched a male Shrike for some time, and seeing him fly to a thick hedge ruming at right angles to the 


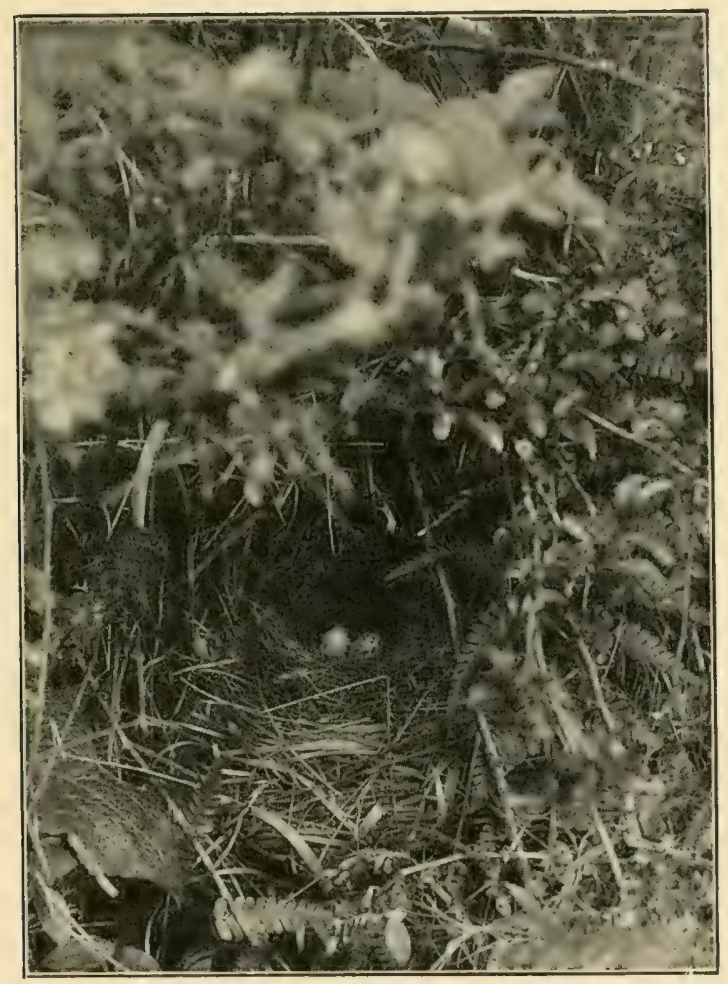

YELLOIV I3UNTING'S NEST.

June 5, rgo2. Wales. 

line, concluded that his nest was there, and so it proved. It contained half a dozen eggs of the creamcoloured type. This species' eggs differ to a marked degree, but are always of the same type in a clutch. The handsomest variety I always think is the one with the bright salmon-pink ground, marked with chestnut and lilac-grey, whilst some of the green types are very attractive. A carefully selected series of these eggs makes a very pleasing show in the cabinet. The nests differ just as much, too. The usual type is composed externally of dried stems of grass and a few roots, with a flake or two of wool and some cocoons round the rim, lined with finer roots, perhaps a feather or two and a little horsehair. Occasionally a good deal of wool is used on the exterior. It is a compact structure enough, but built very loosely in its site, and is seldom more than six feet from the ground, though I have seen it as much as fifteen. Nor is the bird's larder invariably close to the nest, as occasionally I have found it nearly a hundred yards away.

June II th.-Punted myself across the river and examined the bank somewhat carefully; almost as far as the town. I only saw one Kingfisher. On a fallen tree-trunk, dipping in the stream, was a Waterhen's nest with seven eggs; these eggs were remarkably small varieties.

Close to the town, in the hole of a pollard willow, I found a nice brood of Pied Flycatchers, being first attracted to them by the actions of their parents. It was a pleasant sight to see a brood of such local bircls going off in safety, for nowadays few of our 
rarer birds are allowed to nestle in peace. The dealer is the worst offender in this respect, for he stops at nothing, and will take as many clutches of a good thing as he can find. I expect that many Redstart's eggs are palmed off as Pied Flycatchers', as away from the nest and parent birds they are not as a rule to be distinguished. By the way, these two species will occasionally lay in the same nest, and he would be a bold man indeed who would say for certain which egg was which. On the way home I tried to find a Nightjar's "nest." This bird, I am told, is less plentiful here than in former summers, and I think that this same remark applies to many of our smaller birds, such as IVagtails, Sivallows, Martins, and yet they cannot have suffered so much at the hands of bird-catchers as Goldfinches, Linnets, and Redpoles have.

Of course all migratory birds are subject to some fluctuation in numbers annually, but this can well be understood, as a good deal depends on the sort of passage they have, when many may die from one cause or another.

Jume $12 t h$. Walked into $B$. by the river and was much interested in watching many pairs of Sandmartins, which are nesting in the river-banks. Bircllovers will have noticed that some nests of this species contain a plentiful lining of feathers, whereas others have none at all. Now, I think that these feathers are added after the young are hatched, and I should be glad to know what other naturalists think about this. In a highish piece of bank I found a Kingfisher's nest, but it must have been one 


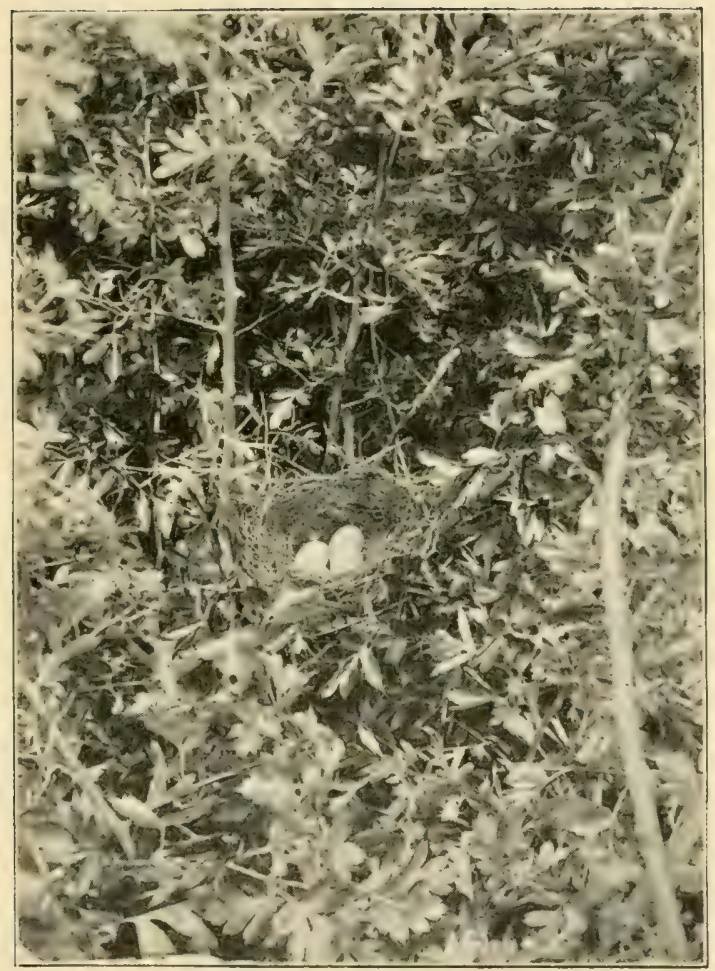

CUCKOO'S EGG IN GREENFINCH'S NEST. 

which was robbed last year, for it was dug out. The ancient mass of fish-bones, crusted with age, was as large as a good-sized plate. On the way to the C. hills I was shown two Spotted Flycatchers' nests, one built on the remnants of an old Thrush's nest, the other among some roots protruding from a bank on the confines of a quarry. It is not unusual for this Flycatcher to build on the ruins of another bird's nest, and several such instances have come under my own notice. Close to the Black Bog I found a Snipe's nest with a brace of eggs in it. They very much resembled a small Peewit's egg, not being as richly marked as the usual run of Snipe's; in fact they showed little red in the markings. The nest, simply composed of a little cotton grass, was in a tussock, and I found it quite by chance, for the bird was not "on," though I flushed her close by. Besides this we found a Meadow Pipit's nest with five eggs and a Peewit's with the usual four.

June I 3 th. - To-day I heard of the finding of a Fern Owl's nest a few days back. As yet I have not discovered one this season. Walked into B. by the road, but just opposite G. farm, getting some few yards off the beaten track, flushed a Titlark from her nest, which proved to contain a young Cuckoo just hatched, a Meadow Pipit in the same state, and one egg, whilst just outside the nest were two more eggs. Being extremely interested in the matter, I watched for some time, and had the good fortune to witness the young Cuckoo eject the egrg from the nest. It first got the egg between the side of the nest and itself, and working under it, with great exertion 
succeeded in throwing it from the nest, but it failed several times before achieving its purpose. I replaced all three Pipit's eggs before leaving. Walking home by the line, I noticed a largish nest in a wild rosebush, which on examination proved to be a Shrike's, containing one egg of the pinkish type. I heard a Wood Owl hooting away, early as it was; but this

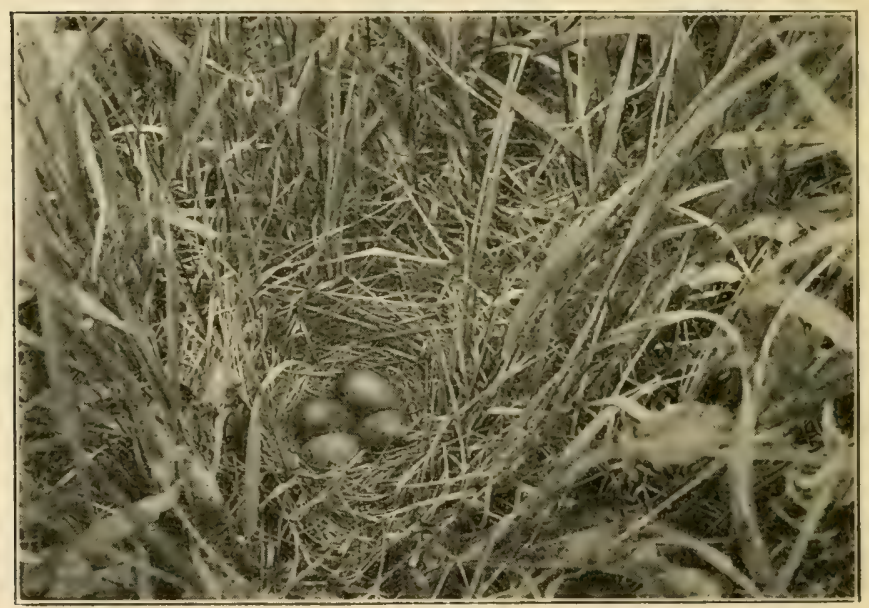

SKYLARK'S NEST.

species will sometimes at long intervals hoot all through the day, especially should the weather be sharp; but then the hoot is more subdued and not so full of music as when heard at night.

In a very thick briar-bush was a Bottle Tit's nest, which had hatched off successfully, and as it was rather a nice specimen, I cut it out, not without some difficulty. At the top of the hill I sat down in the 
bracken and enjoyed the singing of several Woodlarks. What extremely sweet notes they have! This bird is easily distinguished by its flight alone from the commoner Skylark, for it has rather a squat body and short tail, and I always think, though perhaps the resemblance is fanciful, is like a bat when on the wing. At close quarters the very defined whitish streak above the eye characterises it directly, besicles which its call-note and song are very different to those of the ordinary lark.

June I4tho-I am glad to see that the mud shell of the Martin's nest which the Sparrows usurped, has fallen down. I wonder if the former mean to make another attempt under my eaves. Visited the Grasshopper WVarbler's haunt once more, but our search only revealed a Linnet's nest in a gorse-bush from which the young had flown. Visited the Fern Owl's abode on the G. rocks and flushed two couple, but I could find no traces of eggs. Yesterday I visited the young Cuckoo, and found that it had turned out all three eggs as well as the young Pipit, which lay dead outside the nest.

June I 5th. -Walking along the metals in the morning I watched a Shrike for some time, but failed to find his sitting mate. It rained continuously, and was a good deal wetter in covert than out of it, for I went through some thick scrub, where in a wild rose-bush I found a Garden Warbler's nest with young. This Warbler, I may say, has, I think, only been recorded as nesting in two of the Welsh counties - Breconshire and Pembrokeshire; but here is yet another-Radnorshire. I think, however, that it is 
considerably overlooked, being as it is such a retiring species, skulking in the thickets and densest hedges. It may readily be distinguished from the Blackcap, which it otherwise very much resembles, by not having a black head; whilst the female lacks the chestnut crown of the female Blackcap. Saw a pair of the Black-backed Gulls fly up the river.

June I 6 th. - Walked in along the line towards B., and on the telegraph wires running through the wooded piece of embankment saw a select gathering of birds as follows: A male Pied Flycatcher, a male Shrike, a male Bullfinch and Chaffinch. They were sitting on the wires close together, affording a pleasing contrast of colour. Later in the day made for the $G$. rocks and the Nightjars. In one of the recognised haunts, on a piece of dead fern lying on the rocks, was one egg. The hen Nightjar was on it when I approached, and knowing exactly where she was, I got a fine view of her at close range. Further along the rocks a Tree Pipit fluttered from her home in the bracken, revealing six eggs of the dark purplish red type, and a little further yet a Meadow Pipit did the same, leaving five eggs exposed to view; but the pice de resistrnce was a Cirl Bunting's nest, containing two nestlings just hatched and one unhatched egg. This nest was made amongst the matted bracken and brambles, and I almost trod upon the bird before she left her treasures. The single egg was quite enough to identify the species by, but to "mak siccar" I watched the female back to her home, and besides this saw the male bring food in. This species may readily be distinguished from the Yellow Bunting 


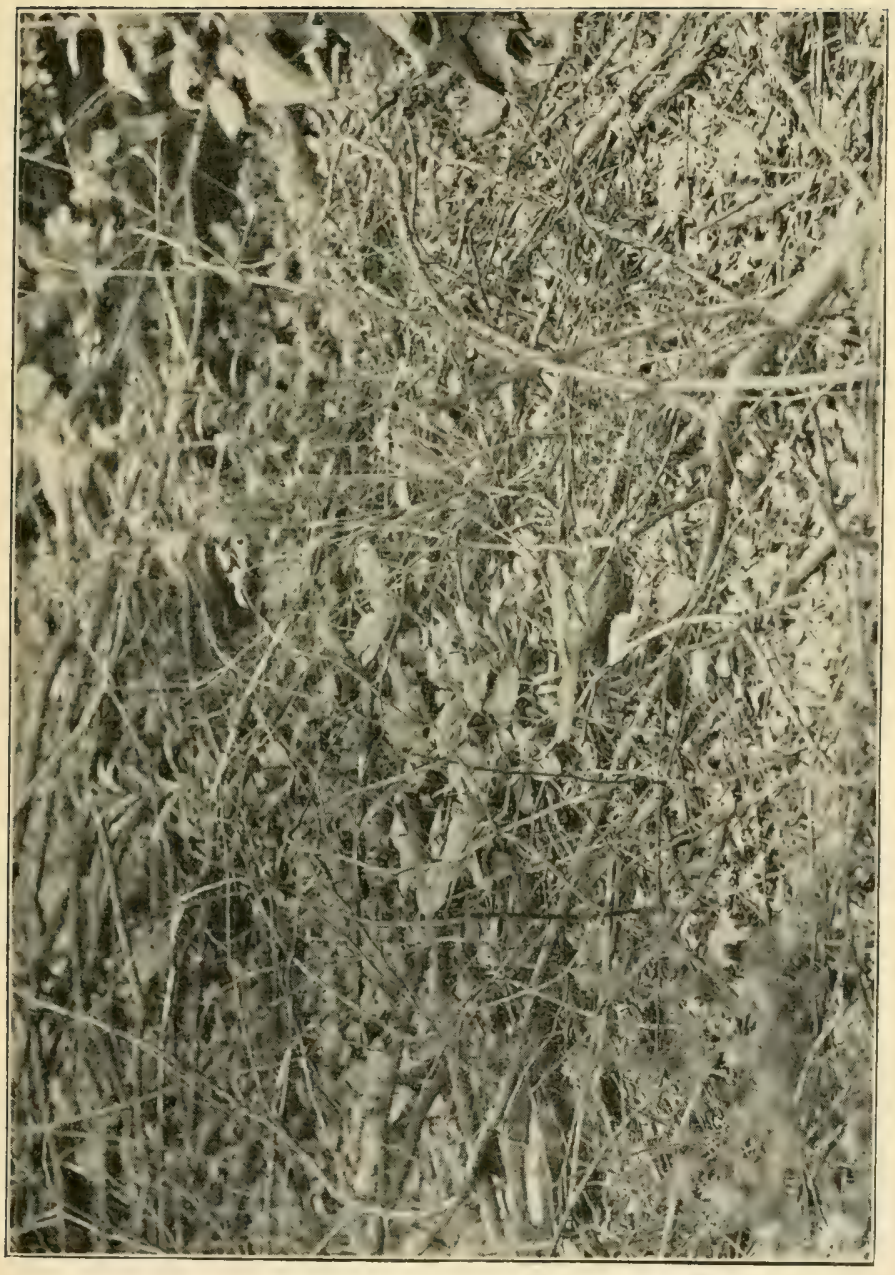

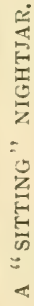



by the black patch on the throat and the olive-coloured rump feathers. The commoner species has no black throat spot, and the rump feathers are chestnut brown. In a sort of quarry close to my house I found another Fern Owl "setting" on two beautiful eggs. The ground colouring of this pair of eggs was china white, and the grey underlying markings were very conspicuous, preponderating considerably over the brown marblings, which were very intense in their colour. Often the brown on Nightjar's egsss runs to a cinnamon colour, and then they are very beautiful. I have proved that some Nightjars, at all events, do not lay their two eggs on consecutive days, a fact which is not generally recognised.

June I 7 th. - This morning I received from Scotland a female Peregrine, about fifteen months old, as well as a clutch of four Merlin's eggs. The Peregrine was shot on the I 4 th instant. The keeper who sent it to me did not recognise the species in its present state of plumage, which of course is not yet matured, the feathers on the back rumning to a brown colour instead of dark slate, and being edged with lighter brown, whilst the spots on the breast and under-parts are rather streaks than bars. I do not think that this falcon breeds until mature plumage is obtained, but possibly I may be wrong in this surmise.

The Merlin's eggs taken on the I Ith instant were extremely hard set, so that to blow them I had to employ the process of maceration. I should say that they would have hatched in about three days. I again visited the G. rocks, where I found a Fern Owl's egg yesterday, but found that it had gone-probably the 
work of a Carrion Crow, though possibly the bird may have removed it, as she thinks, to safer quarters. In a thick bramble I found a Linnet's nest with four eggs - a second brood no doubt. The young Cuckioo is progressing well, and has grown wonderfully.

June isth.-On a fern-covered, sloping hill flushed a pair of Nightjars, close together. For about a week before the eggs are laid these birds may be found squatting close together on the ground; in fact, almost touching one another.

Although the Nightjar has a remarkably tender skin-let any one try to skin one and he will soon prove it-its eggs are distinctly thick shelled considering their size. On the other hand, birds like Ravens, Crows, and the crow tribe generally, which have tough skins, lay very delicately shelled egrss. Of course many sorts of eggs that are laid on the bare soil or rock are thick shelled, but the rule is not invariable, as take the Ringed and Kentish Plovers and Lesser Tern, which all lay thin-shelled eggs on the rough shingle.

Crossing the line on my way back, whilst getting through some wires bordering the metals, I flushed a Shrike from her nest containing half a dozen eggs of the green type. This nest was barely two feet from the ground, in a rose-bush. Six eggs seems to be a very usual clutch with the Shrike, and the Tree Pipit, too, is very fond of the half-dozen.

Jume 19th.-Put in an hour or two in the vicinity of the quarries hunting for Nightjars. The only find, however, was a Blackbird's nest with five eggs. Made for a nest which had been reported to me as a Lesser 
Redpoll's. It turned out to be rather an unusual type of a Chaffinch's home, containing young just hatched.

June 2oth.-Went up over the C. hills, taking the Fern Owl's haunt en route. Had a great hunt for the female whose egg had disappeared yesterday, thinking that she might possibly have removed it, for this species will certainly do this if much disturbed, but I could not flush her. At the Black Bog I heard a Snipe "bleating," but could find no second nest there. Whilst looking for it I dropped across three Meadow l'ipit's nests with two fives and four eggs respectively, but none of them contained a Cuckoo's egg. I was rather surprised at this, for there are many Cuckoos up here on these hills, and 95 per cent. of their eggs must be laid in Meadow Pipits' nests.

I visited the Kestrel's eyrie in the "Marten-cat" rocks. Climbing to it from above, I again disturbed the male from the nest; indeed, he did not leave it until I was just above him. There are four young Kestrels there now, so it would appear that the fifth egg came to no good, nor was it in the "nest." Very shortly the female put in an appearance, so either the cock procured a fresh mate or else the hen was away foraging when I found the eggs just hatching on June $4^{\text {th. }}$.

Both birds were very noisy, flying backwards and forwards, chattering incessantly, though well out of gunshot. Lying at the top of the cliff a little Merlin swept by me, only some twenty yards off, so I had a fine view of him. Clearly there must be a nest here somewhere. The Red Hawks followed me till I was 
quite a quarter of a mile from their sanctuary. Coming back by the G. rocks, early as it was (4 p.m.), I heard a Fern Owl "jarring." I was not surprised, because in Kent I have occasionally heard them doing so at midday.

June 2Ist.-The longest day, but by no means a typical one. Went over to $\mathrm{A}$. and hunted the rocks there for Nightjars, after which I searched for a reported "Raven rock" close by. I found what may be it, but there was certainly no Raven's nest there, either old or new, though in any case the birds would have left it ere this. A pair of Kestrels were here, and sorely agitated too, as well as many Jackdaws. Numbers of young Daws were on the rocks just out of the nest, and a flock of Rooks passing over thought fit to mob one of the Kestrels, which cried out in its alarm. Apropos, I was told by one who knows the country that as he was riding over the E. hills one day he saw the same thing happen, and the Rooks would certainly have killed the Hawk had he not interfered, for they had driven him into a small bush on the open hill. In the evening went for a ramble on the L. rocks, and flushed a pair of Nightjars, and noticing a couple of Woodlarks with food in their beaks, watched them to their nest, which, built on the bare soil in a little hollow under a piece of bracken, contained four young. There was a regular run to this nest quite six feet in length. This was obviously, too, a second brood. We also saw a peculiar Chaffinch's nest, made almost exclusively of wool felted together.

June 23rd.-To-day a pair of House-martins, pre- 
sumably the same pair which were driven away by the Sparrows, commenced a fresh nest in the selfsame spot, for, as stated before, the other fell down, probably because the Sparrows were too energetic inside it, as when they took possession the mud crust had not properly dried. I trust that these window Martins will have better luck this time. By the way, this species will use its wing as a palette for the mud when engaged in building, as I have repeatedly observed.

June 24th.-The Cuckoo is still singing, but very brokenly. Some Tree Pipits are still in fine song, but generally speaking most birds are getting silent now. About sunset, as. I was coming down a slope, up flopped a hen Nightjar some five or six yards in front of me, from under a thorn-tree, as if wounded. I quite expected to find young, and was surprised to find instead two fresh eggrs. I was surprised that this bird got up so far in front of me, as generally this species will sit until almost trodden on; but it was well after eight p.m., and she would of course be more wide awake then than in the daytime.

There are only two pairs of Nightjars on this slope, I think, at most, though it is extensive enough to hold at least half a dozen. Going through a copse, I was very close to a Tawny Owl and her Owlets, not long out of the nest, judging from the bird's solicitude.

June 26th.-Saw a Heron being mobbed by a Buzzard-quite an unusual state of things. Coming home, in the railway embankment I found a Yellow Bunting's unfinished nest and a Partridge's with eight eggs. 
June 28 th. - In a field close to the river was found a Curlew's nest, with three eggs just on the point of hatching and an addle egg. The chicks were dead inside the shells, as could be plainly seen, for a cow had obviously put her foot on them.

June 3oth.--This morning, as I came into the station, I noticed a pair of Yellow, or Ray's, Wagtails on the aftermath. I saw them there on Saturday last, so I think they must have a nest of young, or even eggs, there somewhere. This Wagtail just here is rather scarce, but the grey and pied species are plentiful enough.

July 4 th. - Took a turn on the G. rocks, and flushed a male Nightjar. I also found a Quest's nest in a thorn-tree, with the usual two eggs highly incubated. The last date I heard the Cuckoo was July 2nd. The young Cuclioo in the Meadow Pipit's nest has left it. He was, however, there yesterday. 


\section{CHAPTER VI}

\section{WITH THE SEA BIRDS AT TENBY}

LAST year (1902), at the end of May, we had the good fortune to visit an island or two off the Pembrokeshire coast, close to Tenby.

Here many varieties of Sea-fowl do congregate on the cliffs of the mainland as well as on those of the islands. On May 27th that keen naturalist, Mr. Williams-Vaughan, Mr. Alexander, and ourselves, as well as two boatmen, start for St. Margaret's, a small island some two-and-half miles from the mainland.

Not much bird life is noticeable on the way out, though from time to time we see a few Kittiwakes, chiefly in immature plumage, and these birds have no intention of breeding this season, for no Gulls indulge in marriage till they acquire mature plumage, which is not attained till they have seen at least three summers from the date of their being hatched.

We now get a look at a few Guillemots and an odd Razorbill or two, floating all unconscious of danger on the vast bosom of the Atlantic, which dashes unceasingly against the rugged headlands, 
crags, and prominences of this wild Welsh coast. All these birds allow of a very near approach, hardly condescending to dive till we are all but a boat's length from them.

On a stack rock standing in mid-ocean, like some grim sentinel, sit a few Herring Gulls and Shags, one of these latter a very curiously marked bird ; indeed, it appears to be of a lightish brown colour, paler on the breast than elsewhere. The Gulls are the first to leave as we approach, launching themselves into mid-air like so many huge snowflakes. The Shags remain longer and fly off clumsily, their long, snake-like necks stretched to their full extent. As we near the island a small party of those curious birds, the Manx Shearwater, skim along the surface of the sea, clipping the waves as it were, well meriting the second part of their name. This species is not generally supposed to breed on St. Margaret's, nor do we find an egg belonging to it this day; but we think that it clearly must breed there, owing to its close proximity to the island and the time of day (IO a.m.), for then the Shearwater will hardly be far from its "setting" mate, and these we see are probably males. It is rather unusual to see Shearwaters flying about in broad daylight, as it is distinctly a nocturnal species. Further, we are well pleased to see a couple of Stormy Petrels, or Mother Carey's Chickens, as they are familiarly called, but we doubt if this interesting little species breeds just here, though it certainly does do so on a neighbouring island.

We disembark, and forthwith two of those magnificent Gulls, the Great Black-backed, leisurely leave 
a small stack rock. One we see is in immature plumage and therefore certainly not breeding, but the other is a fine adult bird, possibly a male, and if so, may have a partner somewhere at hand.

Just at this point we notice a bird which puzzles us entirely-a little fellow about the size of a Summer Snipe, but curiously barred on the back and scapulars with white; indeed, it remains a mystery to us at the present moment. It may have been some kind of Phalarope, but of this we are uncertain, as we have but a fleeting glimpse as it flies seawards.

We advance over the shingle towards the grassy slopes of the cliffs. The "yak, yak, yak" of the graceful Herring Gulls resounds on all sides and quite fills the air; their nests we stumble across at every step, containing for the most part fresh eggs. Some more venturesome than the rest sweep past our heads, literally within arm's length, uttering harsh, angry cries.

Indeed, this species pretty well represents the Gull tribe here, though we notice with pleasure one pair of those charmingly beautiful birds, the Lesser Black Back, and further have the good fortune to discover their nest, which, built on a grassy slope of the cliff, is quite apart from the Herring Gull's homes. The eggs of these two species are practically indistinguishable, so, to "mak siccar," we watch one of the Black Backs to its nest, and then all doubt vanishes on the point. This nest contains three eggs, of which two are highly incubated, the third addle, and they are all certainly smaller than any of the Herring Gulls' eggs we have seen to-day. Perhaps 


\section{4 BIRD LIFE IN WILD WALES}

the markings, too, are more defined, running to spots more than blotches and streaks; but in a large series of the two species' eggs these characteristics will not suffice to distinguish them.

Round a bend of the cliff we come upon a pleasing spectacle-some thirty Cormorants incubating on the table-like top of a stack rock, some eighty feet high

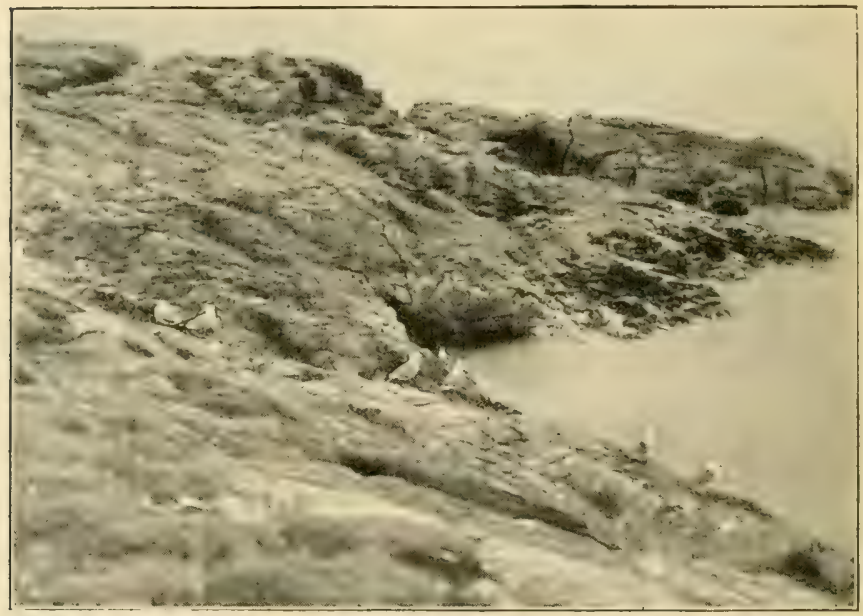

I.ESSER BLACK-BACK GULLS. *

perhaps. Several nests are built on any convenient ledge down its grey and rugged sides. One we succeed in reaching by climbing, and it contains four slightly incubated eggs. From this coign of vantage we can see into some more nests of this species, situate on the main cliff of the island, and notice that at least one nest holds young, hideous in 


\section{WITH THE SEA BIRDS' AT TENBY 225}

their nakedness. Cormorants' nests smell abominably, owing to the decomposing remains of fish in and around them, not to mention the pools of liquid guano collected in all the rock shallows. The eggs, too, have a curiously rancid smell, even on the exterior.

Just here, too, a colony of quaint, gaudy-beaked Sea Parrots, as the Puffin is often called, have their

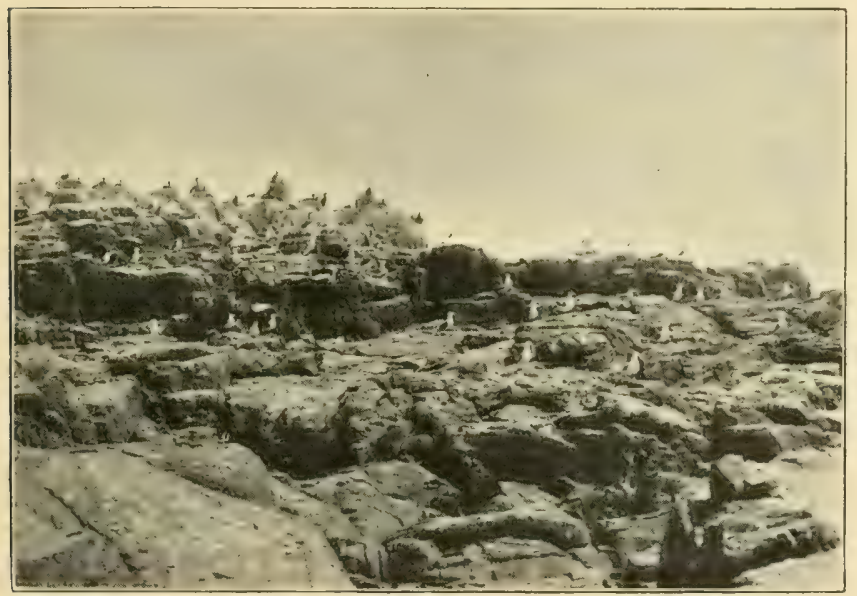

CORMORANTS AND GULIS.

summer quarters. Most of the nests are in irregularly dug holes at the grassy summit of the cliff, but some few are in crannies far down the sheer rocks. After some rather energetic digging with a trowel we succeed in bringing a Puffin or two to hand, and are thus enabled to examine them at leisure, taking good care, however, to keep our fingers out of harm's way, for this species can, if so inclined, inflict a severe bite. 


\section{BIRD LIFE IN WILD WALES}

In most instances where birds are hole-breeders the entrance to the bury assumes a worn and smooth appearance, but we notice the reverse rather in the case of our friend the Sea Parrot; indeed, many of the "earths" look all but unused, a few fish-bones only marking the spot.

Further on still a colony of Shags are located.

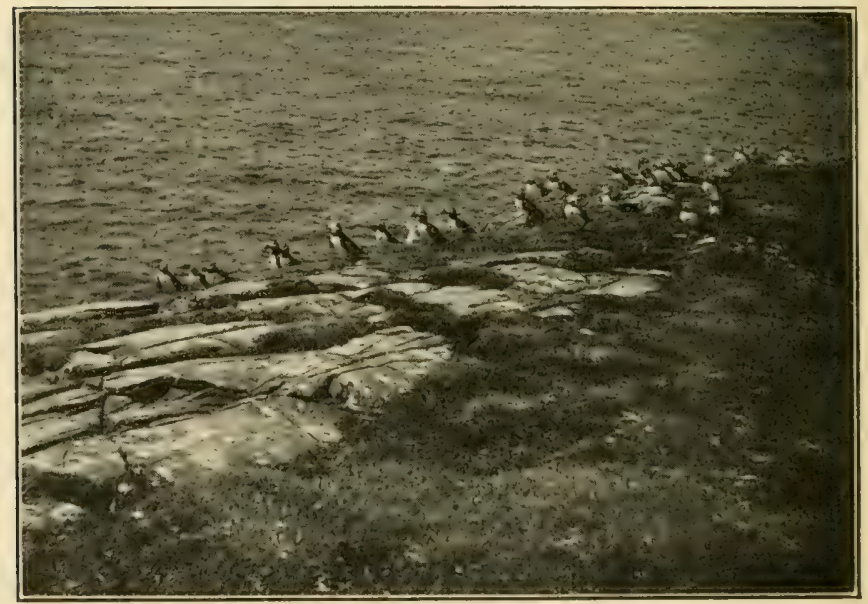

PUFFINS.

Some refuse to leave their untidy nests (built not like their cousin the Cormorants' in open site, but in hollows and caverns of the rocks) until literally pelted off with small bits of sandstone.

A few Guillemots and Razorbills are nestling in the more inaccessible places, but they are not numerous on this island. We are able, however, to climb to one or two of the latter's egrgs without a rope. 
On the 29th instant we take a boat and row leisurely round the mainland cliffs, our chief object being to try and locate a Peregrine's eyrie, though we hear that the pair we are in quest of have already been robbed once this season; but this calamity befell them some three weeks ago, and we do not despair of being able to locate a second clutch of eggs-for often enough this Falcon, should it lose its first clutch, will attempt a second venture. Keeping as close under the cliffs as we dare, we both disturb and astonish countless hosts of Guillemots and Razorbills, the former preponderating, as well as Kittiwakes, Herring Gulls, Shags, and Cormorants in smaller numbers. In parts the cliffs are curiously caverned out, and in some of them every available ledge and shelf is tenanted by the Guillemots, and in places we are able to climb from the boat to some of these ledges and inspect their treasures. We notice that some of the Guillemots (probably for want of suitable accommodation) have laid their single pearshaped egg in veritable holes, just as the Razorbill does, for the Guillemot generally likes an open site on which to lay. This last-named species' eggs differ to a marked degree, and some are exceedingly beautiful. One we find is exceptionally so-of a creamy yellow ground, intricately netted with pinkish brown. On the same ledge is another not unlike, but with far fewer markings. As we draw near the favourite haunt of the Peregrine, a bold, jutting headland of greystone rock, all senses are on the alert, but no sight of this dashing Falcon is vouchsafed us at present; but as we put about after having passed 
this promontory some four hundred yards, a Tiercel comes swooping down wind, say sixty yards above us, and almost simultaneously we hear the shrill "kek, kek, kek" of the Falcon from somewhere behind us. Undoubtedly there was a tenanted eyrie somewhere close, and we still think that we should not only have located but examined it closely only unfortunately the boatmen were unable to land us and that same day we were leaving Tenby.

But having a few more hours on hand, we row across to Caldy Island and after some trouble succeed in landing.

We cross the Island and prepare to descend the cliffs. We have one crowbar only (two is the usual complement for rock-climbing) and the ropes are not of the thickest - but no matter this, for we would fain visit the Guillemot and Razorbill in their haunt. The cliffs here are certainly not more than tivo hundred and fifty feet, but it looks far enough in all conscience and we cannot help thinking of ourselves in fragments on the jagged rocks below should any mishap occur. When it comes to the rub the second boatman refuses to participate in the business at all, and we see that he is visibly moved, shaling at the knees and beseeching us to refrain from venturing over the cliff. Thinking that the man is concerned for our safety, we commence praising him for his wondrous fellow-feeling, whereupon he quietly informs us that he is not thinking of our welfare, but his own, for he explains, "Should the rope break I shall be had up for manslaughter" ; so eventually the other boatman, aged seventy-six, lowers us 


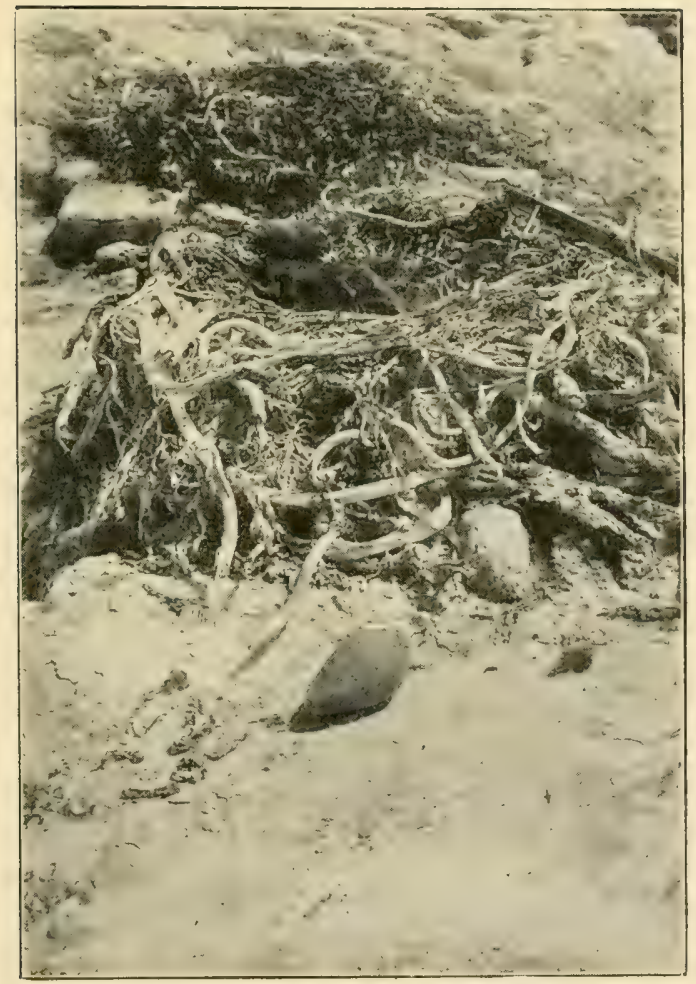

YOUNG CORMORANTS IN NEST : GUILLEMOT'S EGG BELOIV. 

down the sheer cliffside by himself. After about a hundred feet we reach a regular little tunnel in the rock, penetrating to the depth of ten feet perhaps. This tunnel is full of Guillemot's eggs, the majority, however, being out of reach, but there are a few very fine ones, mostly of the blue-green type, within reach. As we said before, the Guillemots here seem to favour niches and hollows of the cliffs for breeding purposes, as the Razorbill almost invariably does. But we can hear some stay-at-home, know-everything, egotistical critic say, "Nonsense! the Guillemot always chooses an open site, a ledge on the cliffside." But if the learned professor will follow us to the wild sea cliffs of South Wales we will speedily convince him to the contrary - that is, if he will venture his precious neck on a hundred feet or so of hemp.

But the enemy goes apace, and we are obligedbut reluctantly - to return to our boat and Tenby. In conclusion we may say that we think a Chough was seen in the distance, but this is by no means a certainty, for we were too far distant to distinguish his coral red beak and legs, and the flight is very Jackdaw-like; but where the Daw is there will the Choughs not be gathered together.

Note- - Young Shags in their first plumage often appear of a brownish colour, but the one we mention above cannot have been immature, for observe the date (May 27th), when at most young Shags would only just be hatched, whilst many would still be in the egg stage. 


\section{CHAPTER VII}

SOME RARE BIRDS IN THE PRINCIPALITY

CHACUN aे son gont; but give us the charms of the Welsh hills and dales-charms which are the more engaging, because here is the last refuge for some of our fast disappearing avifauna. The best time to study these rarities is undoubtedly spring, so let us choose a morning in that month of months, May, and betake ourselves to a valley that we know-one of the most enchanting and wild valleys of all wild Wales.

A haze denoting heat clouds the atmosphere-cobwebs, a shimmer of gauze, cling to every tree and bush and rock, the river, a winding silver thread, teeming with its hardy little brown-speckled trout, dashes with rippling wave over variegated slabs of rock and smooth glistening pebbles - the haunt of the otter. Here, at all events, no shaggy, ironsinewed hounds have invaded his sanctuary or tried to dislodge him from his beloved hill stream, and here, doubtless, he revels in the wild scenery just as we do.

A Dipper pipes cheerily up stream, taking its 
course with greatest precision. Just now he and his mate have a hungry brood to forage for, and very assiduous they are in their duty. Their moss-built nest, wedged in an angle formed by two foamflecked rocks, harmonises wonderfully with them; and by the inexperienced eye is seen with difficulty.

A Grey Wagtail passes overhead volatu undoso, doubtless on his way to a "setting" mate; and from those beetling slate-stone crags on our left the hoarse barking "qualme" of an angry Raven is heard. Here, then, at least one pair of our dusky friends have survived another winter, and having braved all foes successfully, are now engaged in bringing up a promising brood.

Scale the rocks and visit the eyrie: climb carefully; for the slate is treacherous in the extreme and facilis descensus averno and its sequel may be ours. At last we reach a ledge from which the interior of the nest is visible-nearer than this we cannot get without the aid of ropes, but nevertheless a splendid view is obtained. The nest, a huge structure of sticks and heather branches, lined copiously with wool and fur, the exterior freely whitewashed, making it conspicuous from some distance, contains three, no, four well-grown Ravens, and we look down into the intense pinkish red of their expectant mouths, a hue which contrasts admirably with the gloomy grey surroundings-a dash of colour in a monotonous environment. Both old birds are now on view, in their displeasure tearing off the smaller branches and shoots of yon mountainash. They dare not come close, but they would be 
safe enough at our hands, for we are not here to slay, this joyous May morning. In a few days at most these young Ravens will be on the rocks above the eyrie, and will keep with their parents some time even after they have grown strong on the wing.

This picture we leave, and presently the wild mewing cries of a pair of Buzzards attract our attention. Beautifully they sail round one another in spiral curves, the female conspicuous by her larger size. As we near the dingle over which they are circling their cries redouble, waking the echoes of the gorge below, and soon we are gladdened by the sight of their large and rudely constructed home, built on a broad ledge of rock some way up the rugged cliffside. This we can climb to without the aid of a rope and inspect at leisure. Built behind the friendly shelter of a mountain-ash, it is composed of sticks of varying lengths, the larger ones first, and is lined sparingly with blades and tufts of mountain grass; and in some abundance down clings to it as well as adjacent objects. It contains three eggs-ivell marked ones too-richly splashed and blotched with purplish red on a creamy ground. Buzzard's nests vary considerably in their construction. We have seen them lined severally with ivy, moss, larch or Scotch fir branches, but we think their choice is governed by the locality in which the eyrie is situate; usually, however, mountain grasses are called into requisition. A mole and parts of a rabbit, relics of some red-handed foray not long past, lie on the edge of the nest, but here the Buzzard's food consists mostly of carrion, dead sheep 


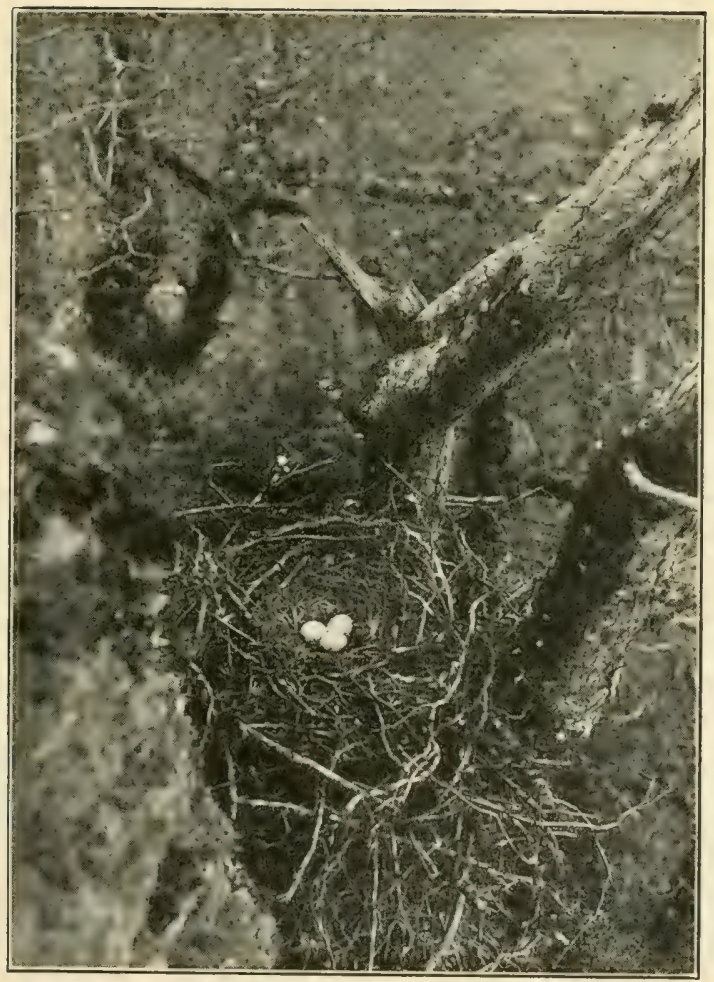

BUZZARD'S EYRIE.

June 4, 1902. WVales. 

in particular, which at times he finds in abundance, especially during the lambing season; varied (and this chiefly when he has young to cater for) by rabbits, moles, mice, and beetles. But who will grudge him a rabbit or two or even a siclily grouse "cheeper" that would do no credit to the "pack"?

To our minds Buteo is a noble-looking fellow, though we must admit he is far from brave, and is frequently beaten off and remorselessly harried by birds not half his size, though as an exception to this we may incidentally say that whilst otter-hunting during the present summer we saw one mobbing a Heron. This year, too, a couple of curious facts come under our notice with regard to this species. The first has to do with his cry, which, usually a clear mewing whistle, wild and mournful but nevertheless a fitting accompaniment to the landscape, be it rugged hills, heathery waste, or leafy woodland, is on this occasion a sort of screeching croak, itcrated several times. The second touches his nesting economy, and in this case we find that two eyries are being used by one pair of birds and an egg laid in each.

The poor Buzzard suffers much from that pest the egg-dealer, and in a minor degree from that sable villain the Gore Crow, which, as we can testify, levies toll from its eggs. We continue our ramble along the rough path skirting the stream, which now sinuously embraces the base of a large and noble, hanging oak wood, which half a dozen years ago was a sure habitat for a Fork-Tailed Kite's nest. Now, alas! we search it in vain, for the greed of the collector and crass ignorance of the gamekeeper and 
farmer have well-nigh exterminated our poor friend. However, our nest-hunt is not altogether fruitless, for we find several Carrion Crows' tenements-a Pied Flycatcher's abode in a hollow birch, and a Tawny Owl's egg in the once home of a Buzzard. But evening now approaches, and as we have a long walk before reaching the charming little inn which harbours us during our stay in the hills, we breast the stiff ascent leading from the valley to the neverending moorland above-moorland redolent with the perfume of brown heather.

Bird life is riotous on all sides. The " peep, peep" of the ubiquitous Meadow Pipit falls on the ear incessantly; far up above us, lost in the "blue," Larks carol joyously; a Peewit wails mournfully as we touch sacred territory, a cock Grouse rises with a loud rush of wings and tells us to "gobac, gobac, bac, bac, back," plainly as any human being; the plaintive and trilling "curlee, curlee" of the Curlew is wafted pleasantly to us by the scented spring breeze, and the "bleating" of a Snipe sounds distantly from some bog-but forward!

As we descend the last hillside, before our goal is reached a large bird sails grandly from a clump of monarch oaks. Can it be? No, too good to be true; yes, surely though the sword-like wings and forked tail of the Red Kite! What a supreme moment! as he sails majestically past us-only a gunshot off. Was ever a better view of so rare a bird obtained in these degenerate days? Round he circles, now hundreds of feet above us, scanning the ground beneath with eagle eye. Then straight 
as a die over yon hill, till he becomes a speck on a cloudless horizon, and afterwards we know that he goes to a ravening brood; and further, we are glad to know that that brood went off in safety to swell, we hope, the feathered throng for years to come.

But rapt in admiration we too leave, making for the little white inn lying peacefully amid these darkening hills, and here pewters of good ale await us, which we gratefully drink with this everlasting toast, "Long life to the Kite, Buzzard, and Raven in Wales." 


\section{CHAPTER VIII}

\section{SOME ROUGH NOTES}

MANY people imagine that the once common Red Kite is quite extinct, but such, however, is not the case, as will have been seen from the foregoing pages, though we fear that his days are numbered as far as the British Isles are concerned. But what else can be expected when we say that we know for a fact of one dealer who finds no difficulty in getting seven guineas for an egg of this species taken in the British Isles?

The so-called "Common Buzzard" as yet decidedly" holds his own in certain parts of the l'rincipality, and will, we think, continue to exist, in spite of collectors, as long as the birds themselves are not shot or trapped. The Raven also continues, but is a scarcer bird than the Buzzard even, as far as the inland localities are concerned. This is somewhat curious; as we think that he is less persecuted than the latter, the chief reason being that he chooses a more inaccessible spot for his eyrie, and it requires a very keen man indeed to carry much rope tackle on a twenty-mile tramp. 
The Peregrine flourishes on the Welsh sea-cliffs, although a great many eyries are robbed annually; still there is little fear of this noble Falcon becoming extinct, for it is a very wary species, offering in this respect a marked contrast to the Buzzard, which is easily trapped. Were the inland cliffs precipitous enough, no doubt many pairs of Peregrines would nestle away from the sea, just as they do in Scotland and the Lake district. Even as it is, there are one or two pairs scattered about in the hills. Mr. GwynneVaughan tells us of one pair which, till about a dozen years ago, nested regularly in a certain inland rock; but as they proved very destructive to the Grouse on an adjacent moor, both birds were shot, and rather oddly the old eyrie was never tenanted by another pair.

It seems an odd thing that the little Merlin is not generally distributed over the Welsh hills and moors, but, as a fact, it is exceedingly scarce. Another bird which is unaccountably absent from these hills is the Hooded Crow; and more than that, apart from the breeding season it is seldom seen in the winter.

Although we have never found a Harrier's nest in these parts, we feel confident that a few pairs still continue to rear their young on some of the wildest hills; indeed, we saw a male Hen or Montagu's Harrier last spring-probably the latter, but it was too far off to say to which species it belonged for certain.

Our advice to those who would study birds in their haunts is to go, when possible, alone, with nothing but their favourite pipe for companionship (be sure that the matches are not left at home), and rather 
saunter along than be in too much of a hurry. Far more is seen by the quiet observer than the man who dashes along. We must say, however, that in very wild, rugged tramps over the hills and moors we prefer a companion-for, to say the least of it, it is awkward to be perhaps from five to ten miles from the nearest succour should a sprained ankle or any other calamity befall one. Many such a wild ramble have we had with a certain keeper of our acquaintance, a capital fellow, nor must we forget to say that we are indebted to him for much information, for as far as local birds go it would be hard to find a more competent observer. A fearless cragsman and splendid walker, with an eye like a hawk's, he is one of the best fellows we know of-for a tramp. He once sav a Raven stoop at and kill a Kestrel which ventured too close to its eyrie, and on another occasion he caught a Kestrel on her eggs, coming silently round a bend of the rocks. Of course he knew of the nest beforehand. Here the Raven and Buzzard flourish, as they must have done centuries ago, numerous Kestrels gladden the eye, whilst Owls, too, are conspicuous, though not so plentiful up in these mountain solitudes as in the better wooded valleys. Altogether it is an ideal spot for the naturalist.

The delicate little Pied Flycatcher is far from being rare in certain favoured parts of Wales; but even here it is much overlooked. As a rule, it is a bird of very secluded habits, frequenting the rotten birches and alders fringing the fast-flowing hill streams; indeed, you will seldom find it far from water. However, last summer we heard of a nest of this species 


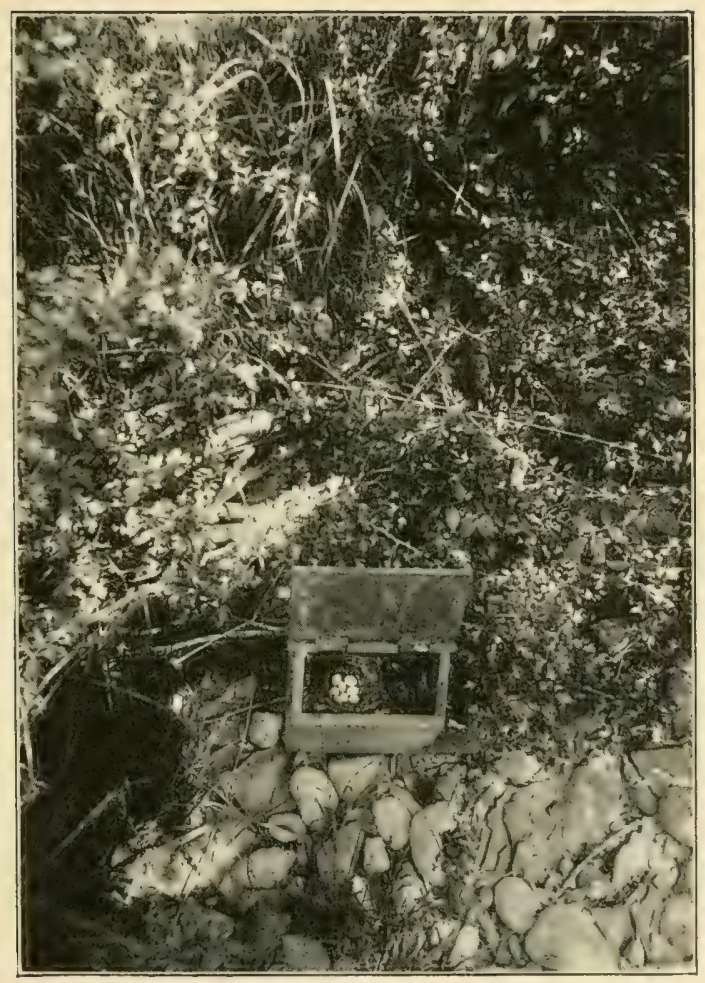

PIED FLYCATCHER'S NEST IN A BOX.

May 26, I003. IVales. 

built in a box close to a house, but this must be regarded as very exceptional. We know of one magnificent wood in the heart of Wales where perhaps a dozen pairs of this elegant species nest annually; and this same wood (composed chiefly of oaks) boasts a Heronry and a pair of Buzzards, as well as the following scarcer species: Brown Owl, Sparrow-hawk, Carrion Crow, Magpie, Jay, all three sorts of Woodpeckers and Wood Wrens, as well as all the commoner linds of wood-haunting birds. We have our suspicions, too, that the beautiful Hobby Hawk nests there as well; and this fact we hope to verify during the coming summer.

The Brown Owls in this wood, perhaps for want of hollow trees, nestle in the Crow's old homes; and we have mentioned finding an egg of this species in the once home of a Buzzard (vide Chapter VII.).

A word now on "generalising." This is, as a rule, an unsafe proceeding, beset with many pitfalls; and in any case a man ought to have had many years careful study of a species before he does so at all. And yet how many, after perhaps finding a couple of nests belonging to some species or another, begin at once to use the word "always" when writing about it. Whenever, then, we have used the word "always" in these pages it will be understood that it only applies to personal observation, and is in no way meant for a generalisation, though we do not believe that a Kestrel ever made a nest for itself, or a Sparrowhawk anything but the contrary. And when the eggs of this last-named species are recorded as having been found in Crow's or Magpie's deserted homes, 
that statement would, we think, on examination, be found wanting. An additional nest, made by the Hawks would certainly be found on the top of the old structure. We have, indeed, found nests of this description; and we may here also remark that the Buzzard has been known to make a nest on the top of an old Crow's tenement, like his smaller confrere the Sparrow-hawk.

Now a word or two on climbing. This is, we are sure, an inborn art, just as cricket and other games undoubtedly are, and though any ordinary, activebodied man may make a fair cragsman and treeclimber, yet he will lack all the nicer points of his more skilful rival. In tree-climbing, never, if you can possibly avoid it, trust to one hold, for should this prove treacherous, destruction or disablement is practically certain. Always remember, too (and this applies equally to crags and trees), that if the ascent is negotiated with difficulty, the descent will be ten times more perilous. In fact, we have been in one or two "tight corners" ourselves for this very reason, especially on rocks. Although rotten boughs are not to be recommended, yet many a decayed branch, with careful manipulation, will bear a good weight, and sometimes it is a case of "Hobson's choice." Weight is no disadvantage in climbing if managed properly, and height is a great advantage-for many a time a tall man will be able to ascend a tree where a short one cannot, because the latter may not be able to reach the next bough, and then, should the tree be too thick to swarm, he has nothing left but to return to whence he came. 
A clear head is, of course, essential, and if a man have no nerve, he had better keep away from cliffclimbing. Turning to that fascinating pursuit, let us advise every one who goes in for it to see that his tackle is all perfectly sound before attempting a descent; also see that the crowbars are properly driven home and the knots in the rope secure. Many an accident is averted by these simple but oftneglected precautions. Always, too, remove all loose rubble at the edge of the cliff where the ropes hang over and put a piece of sacking between the ropes and the cliff's edge. More danger is incurred from falling stones and loose pieces than from any other source.

Now as to egg-collecting. If a man means to collect, we advise his taking the whole clutch, ${ }^{\mathrm{I}}$ for the following reason: All birds as a rule will lay a second clutch of eggs should any mischance befall the first set, and of course we are now speaking of single-brooded birds, for nearly all the doublebrooded ones are fairly common, and a clutch of their egggs more or less scarcely matters. Therefore, supposing a bird like a Pied Flycatcher lays seven eggs, which is not so very unusual, and four of them be taken, she will only rear three young; and then other mischances have to be taken into consideration, such as addle egg, incursions of Hawks, \&c. ; whereas should all seven eggs be removed, she will set to work on a fresh nest and certainly lay five or six eggs, which she has an equal chance of bringing off as she would have had with the three. Here is a case in point:

I I do not agree with this.-O.G.P. 


\section{BIRD LIFE IN WILD WALES}

Last spring we knew of a Raven "setting " on two eggs, an abnormally small clutch, which being taken, Corvus corax promptly built a fresh nest and reared four young in safety.

In conclusion, let us beg all landed proprietors to preserve on their moors and elsewhere our rarer avifauna, for what a pitiable thing it is to see such a magnificent bird as the Kite almost extinct, when we know that once he was common in the very streets of London; and an indigenous species, once exterminated, will never rise again. 


\section{CHAPTER IX}

\section{WITH THE PEREGRINE AND MERLIN IN BRECONSHIRE}

Speaking of the Peregrine, Mr. Cambridge Phillips, in his "Birds of Breconshire," says as follows: "I think slightly increasing. I have known of several specimens killed some years ago, but it never bred here. I am enabled to state this as a fact from the information I received from old Morgan the falconer, \&c."

Firstly, how can a bird like the Peregrine slightly increase in a county where we are told it has never bred; for as all naturalists and sportsmen knowand indeed as its name implies-the Peregrine is a wanderer of the first water, and many doubtless cross the hills every autumn and winter both in Breconshire and the other Welsh counties. "Slightly increasing" is therefore surely a term which ought to be applied either to a breeding species or a regular winter migrant. Secondly, and without further preamble, I may say that this dashing Falcon does breed in Breconshire, and doubtless has for many years. 
I will now describe an eyrie I visited on May I 4 th of the present year. The information came from my friend Captain Beauchamp, of the South Wales Borderers, a first-rate ornithologist and sportsman, and to him be accorded all honour for having discovered the eyrie.

Forthwith, on the date mentioned, I am bestirring by 4.45 a.m., and first of all see how the weather looks, for cliff-climbing on a wet, windy day is no joke. The fates are kind to-day, for the elements look fairly propitious, it being a cold but bright morning, though threatening rain. Next I see to my tackle-two hundred feet of stout manilla, a crowbar, and a handy little driving hammer weighing some four or five pounds, a first-class tool for carrying long distances. By 8 a.m. I have accomplished a long train journey, and am enjoying an excellent breakfast with Captain Beauchamp. He, unfortunately, is not able to come with me to-day, but at 9.45 a sturdy lieeper appears on the scene, and by 10.15 I am bowling along in Captain Beauchamp's dog-cart for our destination. After a long drive a typical Welsh farm-house is reached, where we unlimber and start on our peregrinations. Skirting a wooded hill, and crossing several brackencovered slopes, we at last come in sight of the rocks where the Peregrine is "harboured," and though still fully half a mile distant, all eyes are strained in expectancy. Half this distance covered, and a large bird is visible soaring above the crags-a Raven for certain ; and soon any doubt we may have had on the point vanishes, for he flaps grumbling over the valley 
towards us, "croc, croc, croc." After describing a wide circle he returns to the cliff again, where he is soon joined by his mate, and hearing the disturbance, I suppose, a third Raven joins them for a minute or two. We still continue, the Ravens getting angrier every second (the male especially so, and he delights us by "tumbling" beautifully, as only Ravens can), and are now perhaps but two hundred and fifty yards from the rocks, when, like a lightning-flash, the Tiercel Peregrine leaves his lookout post, and, dashing along the cliff's face, makes a vicious "stoop" at one of the Ravens, which only just avoids the collision by a half-turn of the wing. I can plainly see the great gouge-shaped beak pointed upwards on which to receive the Tiercel should he really mean business, and the latter's legs are extended to the full, but nothing comes of it, and the Peregrine swooping up, makes a rapid ditour of the valley, though still silent.

Another hundred yards on our part, when "kak, kak, kak" from the Tiercel, and out swings the Falcon from her eyrie. Both are now very noisy, dashing past the cliff's face, and alternately taking wide sweeping circles round the valley. The Falcon's note is very different from her mate's, being more prolonged, and resembling rather the following syllable: "Kerech, kerech, kerech"-a piercing cry indeed. A too venturesome Kestrel passes directly under them, but, fortunately for him, no notice is taken, though we fully expect to see him pay the penalty.

We essay to reach the eyrie from the bottom of the 


\section{BIRD LIFE IN WILD WALES}

cliff without using the tackle, though we take it with us, and so the climb begins, and a bad one it is too, especially as we near the eyrie (for we are fortunate in having marked the spot when the Falcon left it). Inch by inch we progress, handing the rope to one another as we gain some sort of a resting-place. Rotten pieces of rock and grass tufts give with the hand grip, and go dashing down to what would be perdition to us; but we continue, and soon evidence of the Falcon's home being near at hand is manifestthe bones and feathers of some unfortunate Carrier Pigeon strewn on a slab of rock. Just here a halt is called, and crouching as best we may on a grassy ledge, watch the Falcons awhile. Their cries now redouble, and from time to time the "Falcon" comes within long gunshot, sign certain of our being near her treasures. Rather to our left is a bold bluff of grey rock bespangled with ferns and mosses, projecting, as it were, over the valley, with at least a hundred fect sheer drop beneath, and after this a slithering, rushing slope of another three hundred or so to the little bubbling stream bisecting the valley, should we be so unfortunate as to slip. This is the place, then, we have to negotiate, and time being up we start on what is real crag work. A projecting and rugged jag of rock bars our way, and round this we have almost to throw ourselves in order to gain a narrow-yes, an all too narrow-ledge (for one tiny slip here and certain death is in store for us). The Rubicon is passed, however, and here we are on the aforesaid ledge which now leads straight to the eyrie, which is situate on a grassy platform, spacious and roomy 
arched above some ten or twelve feet by an overhanging boulder. Yes; as I expected, young, but only one, obviously hatched this very morn, and an addle egg repose in the "scratching" (the Peregrine makes no nest), which is about a foot across, and simply consists of the grass tufts which the bird has furrowed up with her talons, the marks of which are visible in the damp soil. A few of the Peregrine's own feathers, rubbed off during incubation, and those of another Carrier Pigeon litter the eyrie, the feedingledge where the victims are feathered being situate the other side. The keeper now hands me a camera, and I take six snapshots as best I can. The addle egg, very pyriform in shape, is of remarkably good colouring considering it has been sat on for a month, and is of a light yellowish red ground with darker red mottlings. This egg could never have been fertile, for on blowing it the liquid comes out of a clear amber colour, with rather a musty smell, but with none of the fearful odours which attend a fertile egg "gone wrong."

If it was difficult to reach the eyrie it is ten times harder to retrace the steps, but at last, with some manœuvring, we are back on safer territory.

On the way down we inspect the Raven's nest. This must, we opine, be a second attempt (the first clutch of eggs having been taken), for by this young Ravens should have left their home, and the four strapping fellows this eyrie contains will not be ready to leave for at least another week. They are perfectly inaccessible without the rope, though at first blush the place does not look so bad. This 
nest is built on a very small projection of rock, and is large even for a Raven's. Great masses of wool festoon the exterior of the nest, which is well lined with quantities of fur, heather branches, and more wool, the whole concern being liberally "whitewashed," and smelling fearfully. But now collecting our baggage, we reluctantly leave this charming Breconshire valley, and quiet once more reigns supreme; but peaceful it can never be (that is, during nest time) with two such warrior birds as the Peregrine and Raven in such close proximity. Long life to them both!

There is, I believe, only one record of a Merlin's nest being found in Breconshire, and that was taken on the Grouse hill at Wauntinka in June, I 888. The following account, therefore, of one I found on May 22nd, with three eggs, may be of some interest, more especially as the Merlins had taken possession of a Crow's deserted home, which is a thing of extremely rare occurrence, this pretty little Falcon usually laying its eggs in a scratching in the tall heather :-

Starting from the commencement, on April 4th some friends and myself visited a certain little valley where the Kite has certainly bred once. Indeed, the old nest is still up, and this a pair of Buzzards had taken possession of, and had fresh lined it with dead bracken stalks and leaves. Both Buzzards flew from the vicinity of the nest, and were rather noisy, so I fully expected to find their eggs there on May 4 th, which was the next time I visited 


\section{WITH THE PEREGRINE AND MERLIN 255}

the locality. That day it was fearfully misty up in the hills, and torrents of rain were falling; indeed, I scarcely remember a more unpleasant day. On reaching the valley, which is: little more than a dingle, with scattered oaks and hazels on the one slope, gorse and a little bracken on the other, the mist was so bad that I could barely see thirty yards, and badly at that. The moment I topped the slope opposite the oaks I heard a Hawk's cry, which was certainly not that of a Kestrel, and getting down to the stream, just made out a small Hawk leaving the vicinity of the Buzzard's nest. On getting closer, a still smaller one left the nest itself. The Buzzards had quitted the place altogether. On climbing to the nest I found a good scratching in it, but nothing else. As I climbed the opposite slope I once more heard the cry, but left them for the time being, feeling confident in my own mind that they were Merlins though I would not have sworn to it owing to the fog.

On May 22nd, in lovely bright weather, I once again visited the spot, and whilst descending the gorse-covered slope saw a small Hawk leave a Crow's nest, on the left of the Buzzard's. No doubt about its identity in this light: a hen Merlin for certain quotha. On climbing to the Buzzard's old nest, from which they flew on May 4th, I found nothing, but the moment I began the ascent "kek, kek, kek," from the Merlin, as sle circled round the valley with a remarkably quick, though wavering and curiously erratic, flight, twisting about just as a Woodcock will on being flushed. The cry was far shriller 
than the Kestrel's, pitched altogether in a different key. Once she settled on a stone and once again on some wire fencing.

Descending, I climbed to the Crow's old home on the left, and here were the eggs sure enough, three in number and laid in line. They were considerably smaller than the average Kestrel's, and were of a much browner red than the last-named birds. A few twigs, I think from the rim of the nest, had been scraped into its centre, and one bit of green grass had been added. A tuft of wool, too (this a relic of the Crow's lining) was also visible. Several of the Merlin's own breast-feathers and those of a Greenfinch and Lark were scattered about the nest. The female was now particularly noisy, and came within about fifteen yards of me several times, but the male never put in an appearance at all.

I went home and fetched Messrs. Givynne-Vaughan, Owen, and Pike to inspect the "nest," the last-named photographing it several times. On this occasion the sitting bird left her charge when we were quite two hundred yards away, and did not come so close as in the morning, nor was she half so noisy. 


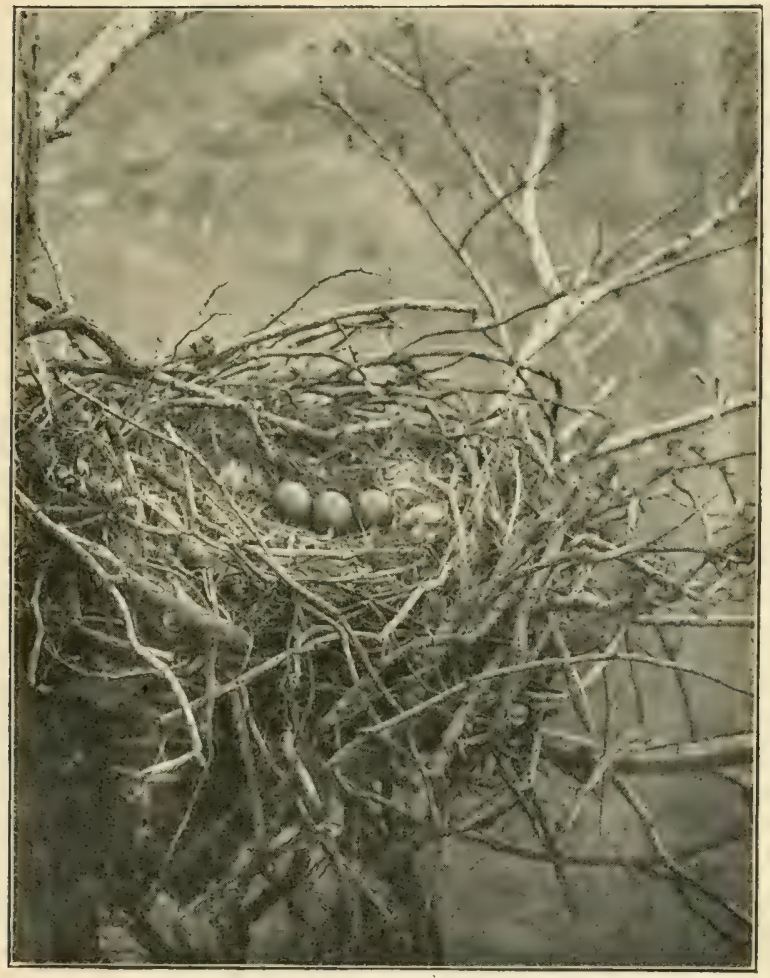

MERLIN'S EGGS IN CROW'S OLD NEST - A VERY UNUSUAL SITE. May 22, I903. Wales. 



\section{CHAPTER X}

IN THE NEST HAUNT OF THE KITE (IILVUS REGALIS), 1903

ONCE common, even to the wonderment of foreigners, in the British Isles, the Red Kite is now reduced to a miserable remnant of some four pairs and an odd bird, which endeavour, but with ill success, to breed in a few chosen haunts in the Principality. I hear of a few pairs besides in Scotland, but until better evidence is forthcoming I must decline to believe this statement.

It may be of some interest, then, to relate my experiences with the Kite during the present year (I903).

At last measures have been taken (alas! all too late, I fear) to protect as far as possible this truly magnificent bird of prey, and the members of the British Ornithological Society having subscribed liberally (all honour to them for it), matters were placed in the excellent hands of Dr. Salter, a firstclass ornithologist; but as duties at Aberystwith kept him tied during the spring and summer, he placed the whole business in my leeping. The public 
hardly realise what difficulties we have had to contend with, for the few Kites left breed on ground which is hardly preserved, if at all, and are therefore at the mercy of any vagabond who may chance to find them. Besides which, Welsh farmers and shepherds are so suspicious of strangers that it is extremely difficult to get information at all, let alone reliable information. Another thing is that all too frequently they confound the Kite with the Buzzard, and on more than one occasion in my own experience a reported Kite's nest has turned out a Buzzard's. This latter species is often called the Kite in Wales, and the Kite the Fork-Tailed Kite, so altogether one has to be extremely careful in accepting any information.

The Kite, though a tree-builder in our Islands, has nevertheless become almost a "hill bird," for it is in the oak woods "hanging" on the mountainsides that it makes its nest. The reason, I think, that the species under notice has vanished quicker than the Buzzard is because the latter prefers a more secluded spot to breed in and confines itself to such diet as moles, mice, rats and rabbits, whereas the former commits fearful depredations among chickens, ducklings, and suchlike farm produce. One can well picture the irate farmer getting down his ancient muzzle-loader and laying low the Forktailed Kite with a charge of "slugs," as it swept down for the last of a promising brood of goslings. Nor can one fairly blame him, for he had but himself to depend upon, with no master to make good the damage. 


\section{IN THE NEST HAUNT OF THE KITE 261}

Once quite a confiding bird, the few Kites left (except at the nest) have become the shyest of the shy, and this is the reason, I think, that the little "colony" under notice has existed so long. But to turn to the present year.

The first Kite I saw this year was on January 28 th, whilst taking a ramble along a certain range of hills. He flew over me about a hundred yards up, going quicker than is usual with this species, making for a haunt in which a pair tried to breed regularly until last year. This quick flight is, I think, only adopted when some distance from their usual habitat.

March I th th. - Captain Lindsay Phillips and myself took a thirty-mile walk, going through the heart of Kite country; but we only saw one the whole day, and that but a fleeting glimpse as it glided along a wooded hillside, where up to about I $\$ 93$ they nested regularly. We were at one time during the day at a regular nest haunt of this species, but no Kite was to be seen. This all points to the probability of this bird not frequenting the breeding district during the winter and early spring. Certain it is that it is a great wanderer, going miles in its hunting excursions.

On March 27th I was again in the Kite's haunt, and in the morning examined last year's nest in an oak wood where they try and rear a brood annually. It was in a moderate-sized oak, some twenty-five feet up in the first good fork, and was a big concern of sticks lined with mats of wool. Any rag or paper which may have been there in egg-time had rotted during the winter. Coming back by this same wood in the afternoon I had a fine view of a Kite being mobbed 
by a Crow ; the time then being twelve minutes past four. The Crow kept getting above him some twenty feet as far as I could judge, and then "stooping," not straight and strong as a Peregrine would, but very much on the slant. The Kite easily avoided his sable antagonist, however, but never showed fight at all, being in this respect like the Buzzard. After a few short shirmishes the corrus gave it up, whereupon the Kite, after taking a circle above the wood, began to quarter the ground very carefully on a hillside running parallel to it. First a few gentle flaps of his ample wings, then a glide, anon hovering like a giant Kestrel. I could see him very plainly, and noticed with pleasure how much he used his forked tail as a rudder, first inclining one side then the other to catch the passing air-currents. Indeed, the Kite seems to use his tail in flight just as much as his wings.

Once he came within easy gunshot of a farmer and his son who were hedging hard by, and for some minutes was only some eighty yards or less from me. I watched him with great satisfaction, and felt quite sad when at length he disappeared over the hill.

On April 3rd Dr. Salter and Mr. Forrest, who were stopping with me, visited this same locality in pouring wet weather, but saw no signs of a Kite by the wood over which I saw one on March 27 th, nor could we find any trace of a new nest. Mr Forrest photographed the old nest, which was in the same state

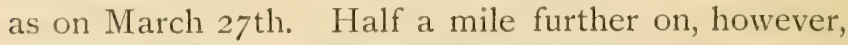
over a fine range of rocks, a Kite was visible working 


\section{IN THE NEST HAUNT OF THE KITE 263}

steadily against the storm about four feet above skyline, making for the wood we had just left, but he was soon lost to view on the opposite hill. We now ascended a fearfully steep gully, wooded at the top, where a pair of Fork-tails sometimes venture to nest, but beyond a very ancient tenement, nothing was forthcoming. Proceeding from the top of the gully, along the ridge of the adjoining hill we dropped into a big oak wood growing on its side, each taking a different line, and I was fortunate in the extreme, for, topping a rise in the wood suddenly, a splendid Kite left an oak-tree some forty yards distant. Catching her just in the right light, I saw many details of her colouring. (I say "her," for, judging from the almost white head, I think it was a hen bird): the red forked tail, bronzy brown upper plumage with lighter edgings, and the very lightcoloured head. Sweeping out of the wood, she was soon lost to view. In a thin but tall oak growing hard by was a large nest, which I was very soon inspecting. A Crow had originally built its nest in the topmost fork, and upon this foundation the Kite had made a fresh structure of sticks and twigs of varying length and thickness, lined at present with moss, wool, and tufts of scirpus grass.

April 4th.-Messrs. Givynne-Vaughan, Salter, Owen and Forrest accompanied me to a spot where up to last year the Kites attempted to breed regularly. The weather was very bad. A pair of Buzzards had taken possession of and were lining the Kite's ancient nest which is in its way quite historical; the Raven, Buzzard, and Kite having used it in turn. It is built 
in one of the topmost forks of a giant oak growing on a steep hillside. In I90 I Mr. A. GwynneVaughan, at his own expense, tried to do something for them, and had barbed wire twined round the tree; but all with no avail, for the egg-snatchers came by night (I have always supposed with a rope to throw over the first branch) and sacked the nest.

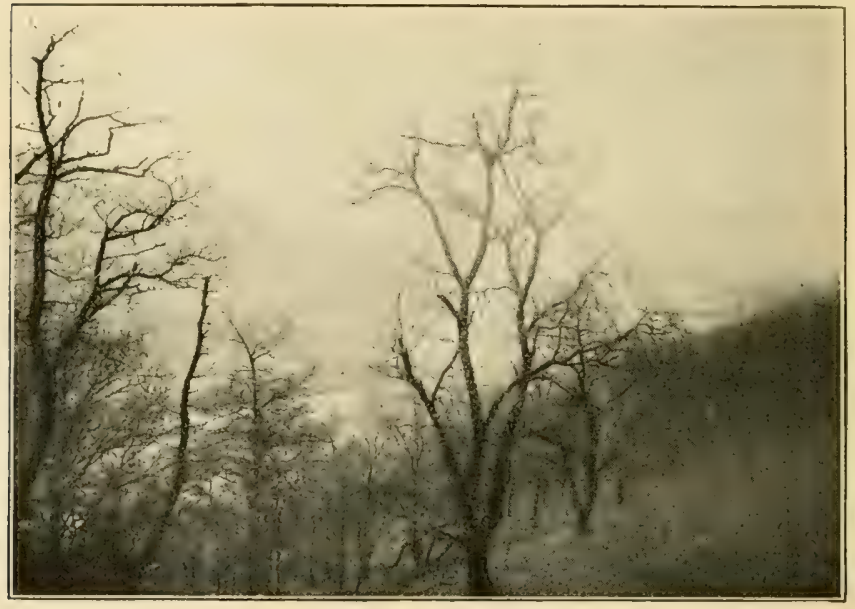

OLD NEST OF KITE.

Iarch IG, IoO2, Wales.

This pair of Kites have now quite forsaken the district. . . The best part of an hour's walk now brought us to a shepherd reported as knowing something about the Kite; but as he insisted that he daily saw three or four feeding on some ant-heaps close to his house (!) we gave him up as hopeless and proceeded to the house of a bird-loving carpenter some 


\section{IN THE NEST HAUNT OF THE KITE 265}

miles away. Fortunately he was in, and our hopes rose when he informed us that a few days since he had seen a Kite leave its nest in a spruce fir. Accordingly off we started in high fettle, but on being shown the tree in the distance our hopes sank to zero, for it was growing by the side of a frequented road, the last place in the world a Kite would choose to rear its young.

On reaching the tree our carpenter friend pointed triumphantly to a nest about two-thirds of the way up. That thing the nest! Why 'tis nothing but a squirrel's "drey:" The Kite was reported as having left it with wool in its talons (!) I need hardly say that we turned homewards downcast men.

April 8 th. - At 3.45 a.m. Dr. Salter and myself rose and started on a very long tramp. Salter was going to walk most of the way back to Aberystwith. Just after passing through a certain village $I$ thought that I saw a pair of Kites sailing over a distant wood, and in this I was justified, for in a few minutes we both had a fairly good view of one. It described a few small circles over a field, at times hovering something like a Kestrel, probably on the look-out for moles, and then, gliding across the road, was quickly lost to view.

This raised our hopes considerably, for hitherto we had never dreamt of Kites frequenting this locality for breeding purposes, though not far distant was a likely looking hanging oak wood which might harbour them. Later on we passed within measurable distance of this very wood, but saw no more encouraging signs.

Presently I left Salter in a valley many miles away, and, cutting over the hills, visited the nest we found on April 3rd. I saw nothing of the Kites themselves but 
the nest had improved wonderfully. The birds had trodden down the wool, moss, and grass tufts, whilst more sticks had been added to the rim. As adornment a few small bones - those of a rabbit I thoughtand nearly the whole of a lamb's skin, with the four small hoofs intact dangling into the nest. This latter article was well woven into the sticks.

April I th.--Visited the Kite's nest again. When about half a mile from it, whilst watching a raven being assailed by a pair of Carrion Crows, a Fork-tailed Kite appeared on the scene, sailing about a yard above sky-line, as is their custom. The nest did not as yet hold an egg, but a varied assortment of rubbish had been added, including the whole of a fowl's leg, claws and all (I think that of the Spanish breed from its grey colour), bones, grey worsted and thin rope with more moss, wool, and hair. A few bits of down were clinging to the sticks of the nest, whilst several splashings showed on the branches beneath.

April i 8 th.-Was at the Kite's nest once again. Both Kites were soaring and circling wonderfully above the wood. Presently they took different courses, one making for a distant wood where they often try and breed, the other for an adjacent valley. There were no eggs yet, but more wool and moss had been added to the nest. In spite of this I began to doubt if it would ever come to anything.

I now went on to the place where Dr. Salter and myself saw a Kite on April Sth, and getting hold of the keeper, took a walk round the place; first of all going through a fine wood of mixed trees-oaks, beeches, Scotch and spruce firs, all of which were of 


\section{IN TIIE NEST HAUNT OF THE KITE 267}

great size. This wood boasts a Heronry (between twenty and thirty pairs), and by this most had young. The nests were built on the tops of the Scotch firs. In this very wood last spring a pair of Kites made a nest in the fork of a giant oak, but blasting operations drove them away, and they had not returned this year. The keeper told me that at the end of January he saw six Kites in the air together and a pair repeatedly since. Accordingly, he piloted me to a wood (the very one that Dr. Salter and myself had looked upon as a likely place for a Kite's nest on April Sth), where he said that a pair of these splendid Hawks had nested regularly for the last thirty years.

When still a great way from our point we both sa:v two enormous birds over the wood which looked for all the world like Kites, and in this we were justified, for getting down to the valley, in addition to three Buzzards, a beautiful Kite came sailing overhead. His mate did not put in an appearance. We now hunted the wood, which was chiefly composed of oaks, many of which were overgrown with ivy. The keeper showed me a two-year-old Kite's nest from which some brute shot the hen, for she was found in a decomposed state at the top of the wood.

No fresh Kite's nest was forthcoming, but I in. spected a Buzzard's, built in the fork of an ivied oak. There were no eggs in it; but quantities of fresh ivy leaves had been brought as a lining. As we left the wood the same or another Kite was on view, soaring over the valley. It soon vanished over the opposite hill, but I went away feeling sure that a pair of Kites 
meant nesting in this wood, though I had seen nothing which looked like the real article.

April 22nd.-Visited the Kite's nest which I first found on April 3rd. Neither of the birds were on view, but more lining had been added-chiefly scirpus grass and wool with one small Scotch fir branch, foliage and all — but a stick was right across the nest, which looked far from healthy, and I was then convinced that the Kites did not intend to use it for breeding purposes. However, more down was on the sticks and fresh droppings under the tree. On the way home I saw my keeper friend of the I Sth instant. He reported the pair of Kites as still being about the wood, but as yet had found no nest.

On April 3oth I was again in Kiteland, and visiting the original nest, found no further alterations, so came to the conclusion that this must be either the attempt of a pair of barren birds or else the "play nest" of a pair which might be breeding elsewhere.

I now went to a wooded gully adjoining this wood, in hopes of finding something there, but beyond some Pied Flycatchers I had no reward, so proceeded to a wood which I had not been through since April $3 \mathrm{rd}$, never dreaming that there could possibly be another pair of Kites in this same locality, for the two spots are but a long half-mile apart; and herein I was at fault, for getting in sight of this wood, I enjoyed a sight as rare as it was beautiful-four Kites soaring and circling in the air together. No words of mine can do the scene justice; but I stood there rooted to the spot for fully five minutes, watching their acrial 


\section{IN THE NEST HAUNT OF THE KITE 269}

evolutions. After this one pair took their departure, whilst the other kept more or less in the vicinity of the wood, and through this I now worked. The ancient nest there had been patched up to a certain extent ; more sticks added, some large mats of wool and one piece of blue-striped calico woven into the sticks. It did not look at all healthy, however, nor did the-Fork-tails come over me whilst I was inspecting it, so I came to the sad conclusion that through my short-sightedness in not visiting this haunt between April 3rd and 3oth some rascal had once more looted the Kites, for by this date Kites should be "setting" hard. Coming out of the wood, I again saw one Kite, and a mile further on yet another -both, I think, the original pair.

On the way back I visited the keeper in whose beat the wood is I visited on April I 8th. He had found no nest, but had seen both Kites in its vicinity.

I see from my diary of May 5 th that I saw a Kite in a most unexpected spot whilst looking up a pair of Buzzards. This must be a single bird which has its beat over a large stretch of country; for if the same, it has been seen at points well over twenty miles apart. This distance is, of course, nothing for a bird like the Forky-tail; but at this time of year it all tends to show that this one is unable to find a mate.

On May I 2th, whilst taking a hill-walk, I again saw a pair of Kites, but they were, I imagine, the pair belonging to a haunt already mentioned, for I was not more than five miles distant from it. It did not look well to see them both together at this date. 
They were soaring in spiral curves round one another, just as the Buzzards will, especially in the early spring. Some ten miles from this point I had a fleeting glimpse of yet another Kite, but he was in a locality where there are no woods whatever, so I could only presume that he was the unmated bird before referred to.

May I9th.-A record and red-letter day indeed, for in lovely weather Messrs. Gwynne-Vaughan, Owen, Pike, and myself visited the wood where the keeper has repeatedly seen a pair of Red Kites. I had kept away from this spot for some time now, so that the birds might not be disturbed in any way should they have anything there, which was, of course, extremely likely. We met the keeper in the village, and after a good two miles reached the wood, which was beginning to show its summer finery. The keeper had scen both Kites in its vicinity during the past week, and one yesterday which looked rather as if a sitting bird might be in the background somewhere; but as yet no nest had been discovered.

Gwynne-Vaughan and myself preceded the others by quite a quarter of a mile, and reaching the wood first, sat down to enjoy a few sandwiches, for it was well past midday. As we rose, the Buzzard whose nest I found ready lined on April I Sth flew out over the valley, though she was silent enough to have had nothing there. Indeed, she hardly "mewed" at all whilst I was climbing to her nest, which now contained two eggs (one well blotched at the large end).

From their appearance these eggs looked highly inçubated. 
The Buzzards had been adding fresh materials during incubation-grass and ivy leaves. In the meantime the other three had come up, GrynneVaughan and Owen at once sitting down some twenty yards above the tree I was in, whilst the other two went further along the wood. On climbing down I joined the two first-named, and had hardly done so when Gwynne-Vaughan jumped "p like a madman, exclaiming, "By heavens there's a Kite!" And so there was indeed. The Forky-tail sailed majestically over the valley, and was for the time being lost to view. Mr. Pike now ascended an ivied oak which contained the nest of two years back-the same from which the hen was so ruthlessly shot-whilst we other four sat down to watch operations. Personally I kept a bright look-out on all sides, and spotting a large nest higher up in the wood, got up without a word and strolled towards it.

The Kite Gwynne-Vaughan saw must have just left her nest; at all events, she now returned by a series of circles which got less and less as she neared the centre of the wood, when she was attacked by a Crow. Twice she "mewed," a thinner, higher-pitched call than the Buzzard's, and iterated "wheiou, whew, whew, whew," but beyond putting out her talons once, showed no fight. When almost under the tree containing the nest I had seen, both Kites were above me within long gunshot, circling about in rather an agitated manner, which looked hopeful. It did not look much of a nest, but the moment I got underneath it I knew it was the real article, for a flake of wool and a few pieces of down were clinging to the sticks. 
I never remember climbing a tree in quicker time, and very shortly I made the wood ring again with a loud view-halloa, which brought the other four up "hell for leather."

Here, then, was the Kite's home, built about twenty-three feet up a rather slender ivied oak in a fork where two fair-sized branches left the parent stem. For a Kite's this nest was extremely small, and unless the down had been observed or the bird seen to leave it, might well have been passed, except by the tiro, who climbs to anything and everything in the shape of a nest. Indeed, the leeper had passed it several times, and I well recollected having seen it myself on April ISth, and having remarked that it looked too small to be of any good; though no doubt the ivy growing round it made it look smaller than it really was. It was of rather an oblong shape, made of stich's (those of an oak) of varying length and size, some rather bleached, and was a bulky structure generally, but the cavity containing the eggs was remarkably flat. The lining consisted of mats of sheep and lamb's wool, about the size of my closed hand, some of which protruded over the edge of the nest, tufts of brown horsehair, rabbit's fleck, moss and flakes of wool, whilst as adornment two largish pieces of cream-coloured paper in which my lunch had been wrapped, and which I had thrown down in the wood on April isth. These bits of paper were lying close together, and by the side of the eggs. A thin, sharp twig, belonging to the tree, oddly enough projected through the lining of the nest, which I brolie off, for it was sticking into one of the eggs. These were two 


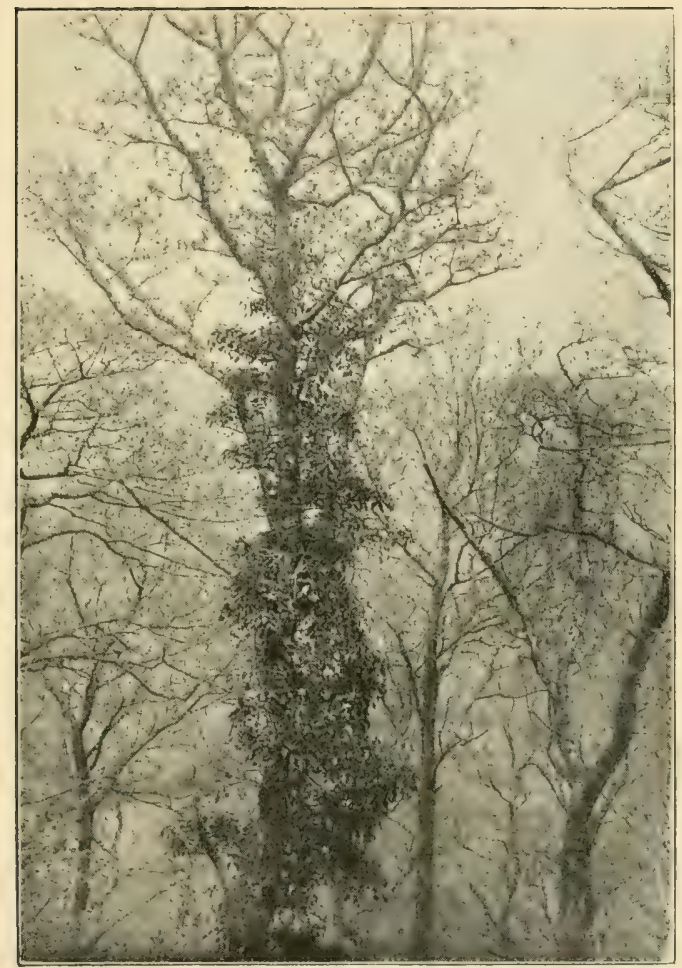

KITE'S NEST OCCUPIED IN I903.

May 19, Ig03. Wales. 



\section{IN THE NEST HAUNT OF THE KITE 275}

in number, more pointed and altogether larger and bulkier than those of the Buzzard, and were of a dirty white ground colour, the one scratched and speckled very sparingly with rust colour, the other splashed and flecked with light yellowish red, with a good many very small dots of a darker shade and a line or two of lilac-red. This latter was the larger egg of the two. Both were much dirtied by the parent bird, and the first described had a crack in it, which I then thought was a "chip," but I did not examine them too closely, as we wished to get away from the spot quickly, so as to allow the parent bird to return to her treasures.

The next time I visited this locality was on May 29th, Messrs. Owen and Pike accompanying me. The keeper met us at the usual rendezvous, the village inn, and he told us that he was nearly sure there were young in the nest, for a few days back the old Kite had attacked his retriever savagely, making it howl again, as he was going close past the nest. IVe got into the wood from above, and when about forty yards distant the Fork-tail left her charge. From higher up in the wood we thought we could make out one young one moving; but on climbing to the nest this proved to be but a mat of wool waving in the breeze, and there were still eggs. The nest had been added to in many ways. Firstly, more sticks had been added, whilst round the rim especially more wool had been put, making the eggs appear to be lying in a deeper cavity; and sure proof of this was that the eggs could not be seen from higher up in the wood (for it was a "hanging" wood), whereas 
from the same spot on May Igth they could be seen fairly plainly with the naked eye. The two pieces of paper had been quite covered with wool, but a piece of very dirty white rag, about a foot long, had been worked into the sticks, and rabbits fleck littered the whole nest, which smelt very musty, caused by the larger egg of the two, which had turned "addle." The other was, of course, still chipped, but I am afraid it was not a proper "chip," as I had surmised, but caused by the offending twig which I had broken off on the Igth instant. The Kite, after leaving her nest, made one or two circles above the wood, and then made off, but returned at intervals, eventually dropping down to the top of the wood, gliding as if on an inclined plane, but she never uttered a sound. Indeed, it is most unusual to hear the Kite cry at all ; and the other day I fancy that it was the combined influence of our presence aided by the Crow's attack, which made her do so. I now feared that this nest would come to nothing, for here was one egg addle and the other probably containing a dead chick. Of a truth the Kite seems doomed to extinction, in spite of every chance being given to at least one pair.

On June 3 rd I once more waited on this nest with the keeper. When about eighty or ninety yards away 1 just made out the Kite sitting on her nest, her head towards us. She allowed us to get within some fifty yards of her before leaving, when she swept up over the lower slope of the wood. The other day, (May 29th), when coming to the nest from the same direction as to-day, I noticed that she was sitting with her tail towards us. I had brought a Buzzard's 


\section{IN THE NEST HAUNT OF THE KITE 277}

egs with me, and put that in the nest, bringing away the addle Kite's egg, which on blowing proved to be in a very odoriferous condition, thus proving that it had once been fertile. More wool had been added, especially round the rim, quite concealing the bit of rag which was there on May 29th ; but a large piece of newspaper had been brought and was lying by the side of the egg, on the identical spot where the previous pieces had been laid. I could not see what "paper" this fragment came from, for it was from the bottom half, and was a sheet given up to advertisements, for I saw several applications for servants and quinine wine advertised (this latter in very large letters) on it. The Kite kept above us whilst we were at the nest, and "mewed" once.

I visited the Buzzard's nest lower down in the wood, and found it contained two young, about a week old, and a freshly-killed rabbit half grown. It was quite warm, and the female could have but just brought it in for she left the nest on our approach Of the two the male was the most distressed.

The last time I visited Kite country was on June I2th, and meeting the keeper, we proceeded once more to the nest. We got within less than twenty yards of the nest and stood looking at it, when "swish!" off glided the sitting Kite, giving us a lovely view indeed. The keeper, who has seen many Forliytails, opined that it was the finest he had ever seen, and certainly she was a grand bird. From her sitting so close, I rather thought that she might have a young one, but in this was doomed to disappointment, for on climbing up I found that she had been sitting 


\section{BIRD LIFE IN WILD WALES}

on the Buzzard's egg, whilst her own lay in fragments under her. ${ }^{I}$ I think that the crack in the egg, admitting air, must have killed the young Kite, for there it lay, corrupt and dead. It was well formed, even to the extent of having down on it; but I think, from its stinking condition, that it had died in the shell, and that foul air made the egg burst.

Whatever the cause, there it was, and a sad fiasco this nest had turned out; but better luck next year.

It is worth remarking, that the Kite upon leaving her nest had to drop quite a yard before getting fairly started, as the stretch of wing is very great. $^{2}$ For this reason they always choose a wood which has been well thinned, so that no adjoining branches may catch them when they take wing. Nor have I ever seen a Kite's nest facing anything but north or some direction with north in it. This Kite must have been incubating for a long time, but, considering this, had lost very few feathers. There were a few scattered about the nest, and some smaller wing-feathers under the tree. As we left the wood, disappointed men, both Kites were visible in the valley below, but after taking a few deliberate circles they made off over the hills.

Later in the day I saw the sight of my life so far - six Red Kites in the air together; and I shall never forget it. There was carrion there, for the

I It is a remarkable thing that this Kite should have continued to "sit" with a broken egg in the nest ; for usually a mishap of this sort is the surest way of making a bird desert her home.

$=$ The Kite's breadth of wing is about five feet and a half. 


\section{IN THE NEST HAUNT OF THE KITE 279}

bark of a raven and then the bird itself rising from the hillside proclaimed as much. A dead sheep was the attraction, then; and there above it in mid-air were six Kites, three Buzzards, and the Raven. Of a truth this sheep should have been preserved! One can almost imagine these Kites comparing notes on the past breeding season. I say "past" because I am sure that no hatch has come off in Wales at all events.

The Kite seems to show a decided social tendency, except just as regards its nesting economy, though in days gone by two or more pairs may have nested in the same wood.

Well, adieu, my poor friend; but better luck to thee next season. And do, I prithee, choose a more out-of-the-way place for the next attempt to rear a brood, as otherwise in the course of, say, five years we shall know thee no more in "Our British Isles." 
280 BIRD LIFE IN WILD WALES

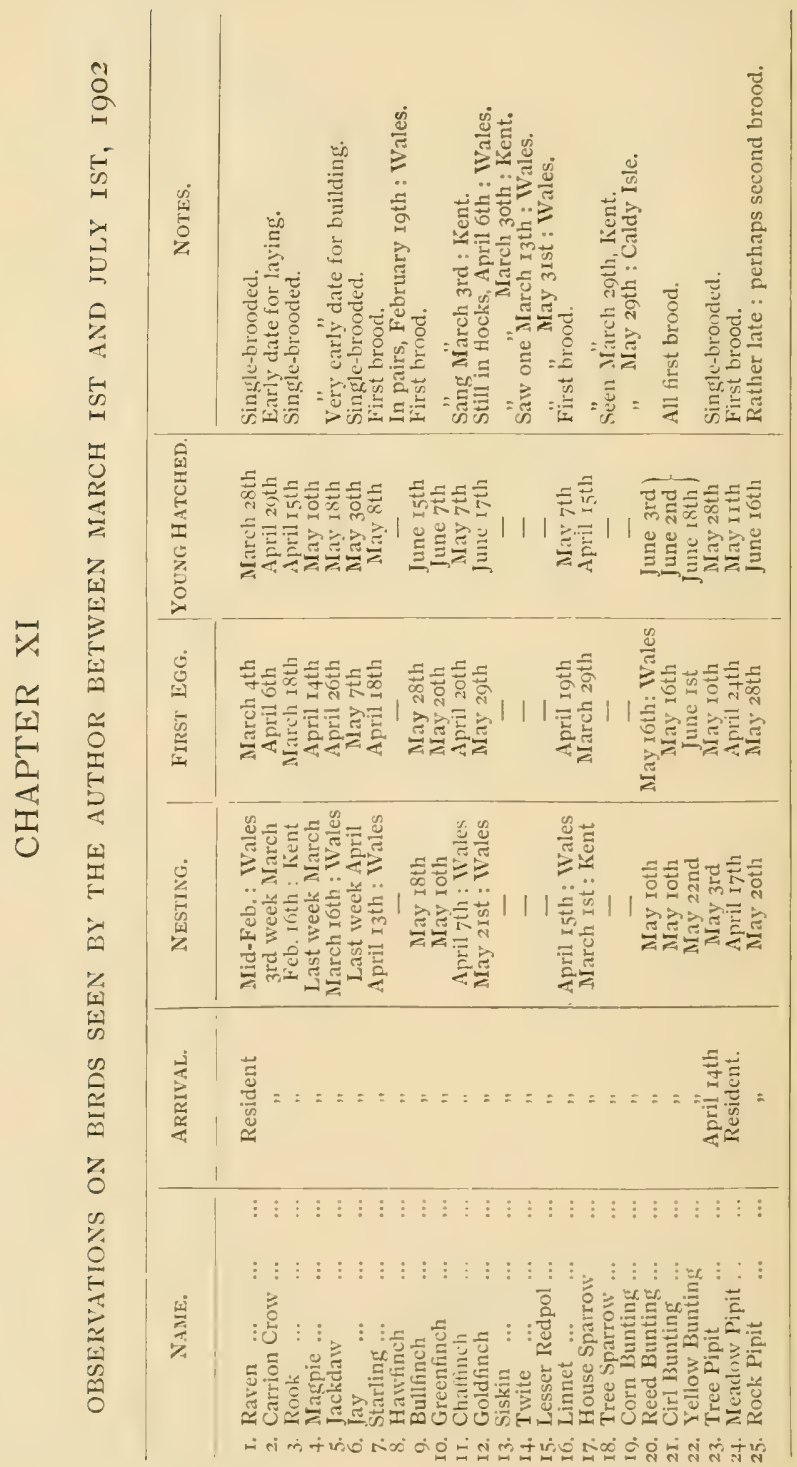




\begin{tabular}{|c|c|}
\hline & 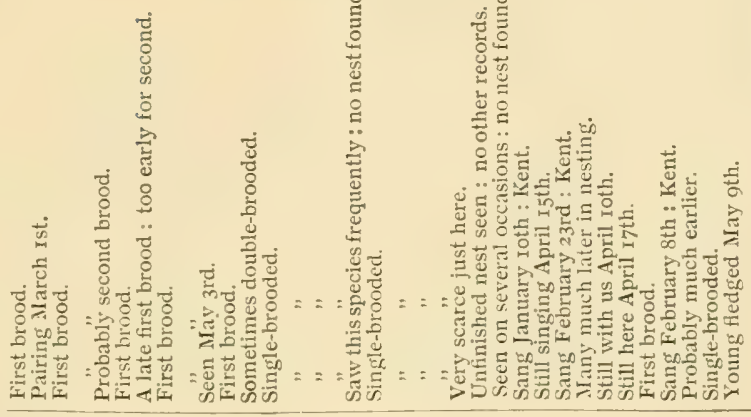 \\
\hline & 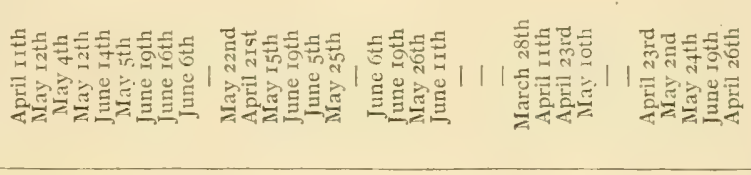 \\
\hline 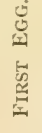 & 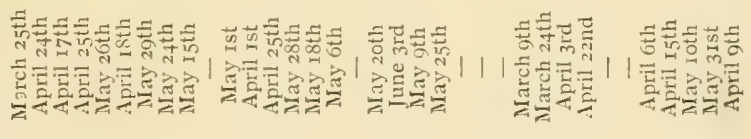 \\
\hline & 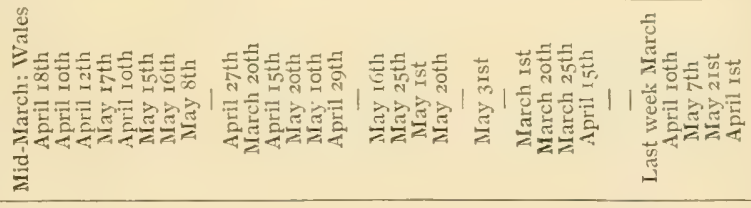 \\
\hline & 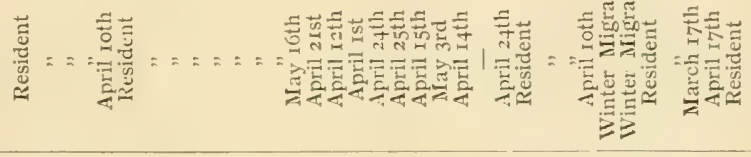 \\
\hline z & 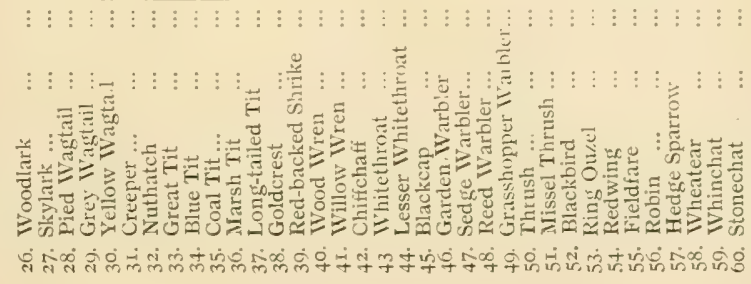 \\
\hline
\end{tabular}




\section{BIRD LIFE IN WILD WALES}

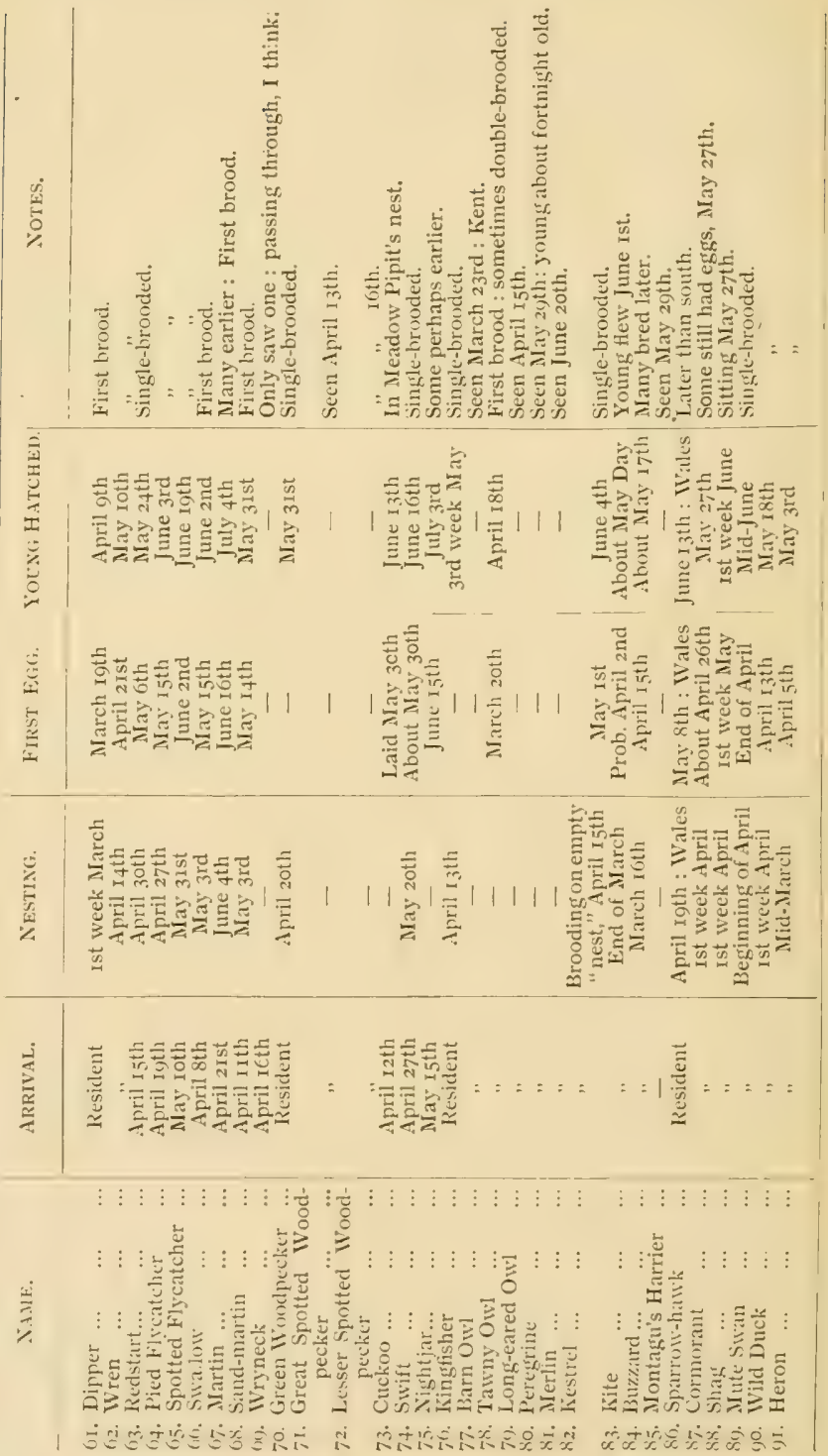




\section{OBSERVATIONS ON BIRDS 283}

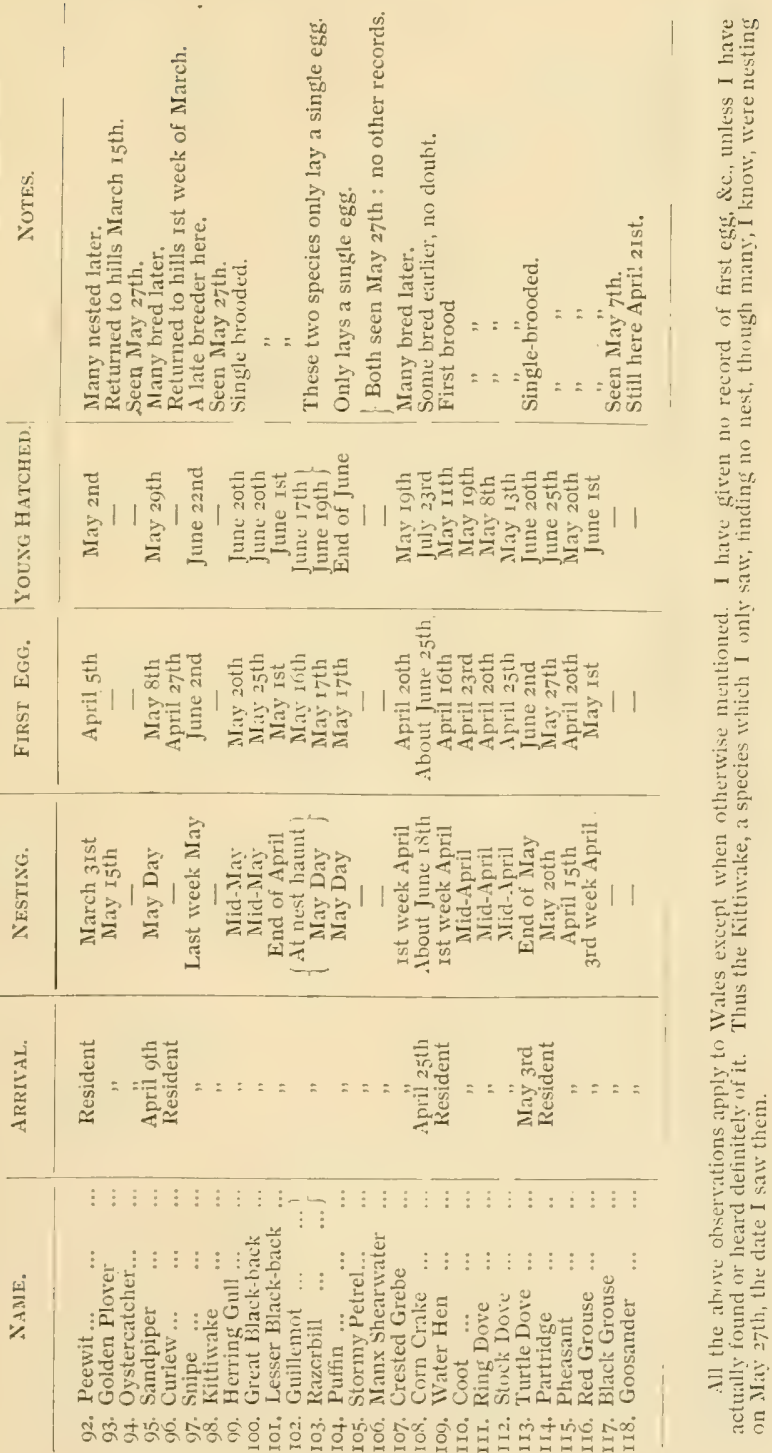


The Gresbam press,

UNIVIN BROTHERS, LIMITED,

WOKING AND LONDON. 
T. FISHER UNWIN, Publisher,

THE

\section{"LIVES WORTH LIVING" SERIES}

OF POPULAR BIOGRAPHIES.

Illustrated. Crown 8vo, cloth extra, 3s. 6d. per vol.

1. LEADERS OF MEN : A Bock of Biographies specially written for Young Men. By H. A. PAGE, Author of "Golden Lives."

2. IVISE WORDS AND LOVING DEEDS:

A Book of Biographies for Girls. By E. CondER GRAY.

3. MASTER MISSIONARIES : Studies in Heroic Pioneer Work. By A. H. JAPP, LL.D., F.R.S.E. Fourth Edition.

4. LABOUR AND VICTORY. By A. H. JAPP, LL.D. Memoirs of 'Those who Deserved Success and Won it.

5. HEROIC ADVENTURE: Chapters in Recent Explorations and Discovery.

6. GREAT MINDS IN ART : With a Chapter on Art and Artists. By William Tirebuck. Portraits.

7. GOOD MEN AND TRUE: Biographies of llorkers in the Fields of Benelicence and Benevolence. By A. H. JAPP, LL.D., F.R.S.E.

ع. FAMOUS MUSICAL COMPOSERS : By LIDIA J. MIORRIS.

Q. OLIVER CROMWELL AND HIS TIMES. By G. Holden PIKE. With 8 Illustrations, including the Bristol Portrait as Frontispiece.

II, Paternoster Buildings, London, E.C. 


\section{THE ADVENTURE SERIES}

\section{POPULAR RE-ISSUE.}

Each large crown 8vo, fully Illustrated. Popular re-issue, 3s. 6d. per vol.; in two styles of binding, viz, decorative cover, cut edges; and plain library style, untouched edges.

I. ADVENTURES OF A YOUNGER SON. BY EDWARD J. TRElaivney. Introduction by EDWARD GarnetT.

2. MADAGASCAR; or, Robert Drury's Journal during his Captivity on that Island. Preface and Notes by Captain S. P. Oliver, R.A.

3. MEMOIRS OF THE EXTRAORDINARY MILITARY CAREER OF JOHN SHIPP.

4. THE BUCCANEERS AND MAROONERS OF AMERICA. Edited and Illustrated by HOWARD PYLE.

5. THE LOG OF A JACK TAR: Being the Life of James Choyce, Master Mariner. Edited by Commander V. LovetT CAMERON.

6. FERDINAND MENDEZ PINTO, THE PORTUGUESE ADVENTURER. New Edition. Annotated by Prof. A. VAMBÉry

7. ADVENTURES OF A BLOCKADE RUNNER. BY WilliaM Watson. Illustrated by ARTHLR BYNG, R.N.

8. THE LIFE AND ADVENTURES OF JAMES BECKWOURTH, Mountaineer, Scout, Pioneer, and Chief of Crow Nation Indians. Edited by Chas. G. LELAND.

9. A PARTICULAR ACCOUNT OF THE EUROPEAN MILITARY ADVENTURERS OF HINDUSTAN. Compiled by HENRY COMPTON.

10. THE MEMOIRS AND TRAVELS OF COUNT DE BENYOWSKY in Siberia, Kamdchatka, Japan, the Linkiu Islands, and Formosa. Edited by Captain S. P. Oliver, R.A.

I1. A MASTER MARINER: The Life of Captain Robert W. Eastwick. Edited by HERBERT COMPTON.

12. KOLOKOTRONES: KLEPHT AND WARRIOR. Translated from the Greek by Mrs. EDMonds. Introduction by M. Gennadius.

II, Paternoster Buildings, London, E.C. 


\section{BUILDER
BRITAIN}

OF GREATER

EDITED BY

\section{H. F. WILSON}

A Set of 10 Volumes, each with Photogravure Frontispiece, and Map, large crown 8vo., cloth, $\mathbf{5}$.

The completion of the Sixtieth year of the Queen's reign will be the mccasion of much retrospect and review, in the course of which the great men who, under the auspices of He* Vajesty and her preilecessors, have helped to make the British Empire what it is to-day. will naturally be brought to mind. Hence the idea of the present series. These bingraphies, concise hut full. popular but authoritatuve, have been designed with the view of giving in each cave an alequate picture of the builder in relation to his work.

The srries will be under the general editorship of Mr. H. F. Wilson, formerly Fellow of Trinity College, Cambridge, and now private secretary to the Right Hon. J. Chamberlain at the Colonial Ottice. Each volume will be placed in competent hands, and will contain the best porm:- ohtainable of its subject, and a map showing his special contribution to the Imprial edifice. The first to appeat will be a Life of Sir Walter Ralegh, by Major Hume, the learned author of "The Year after the Armada" Others in contemplation will leal with the Cabots, the quarter-centenary of whose sailing from Bristol is has recently been celebrated in that crty, as well as in Canada and Newfound:and: Sir Thomas Maitland, the

King Tom" of the Mediterranean; Rajah Brooke, Sir Stamford Raftles, Lord Clive. Eduard Gibbon Wakefieli. Zachary Macaulay, \&c. \&c.

The Series has taken for its motto the Miltonic prayer :-

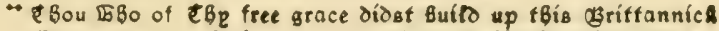
Empure to a glorious and ensiafle BeigbtB. Bitb all bes Daugbter Jolands about Ber, staq us ín tBis felicatic."

I. SIR WALTER RALEGH. By Martin A. S. Hume, Author of "The Courtships of Queen Elizabeth," \&c.

2. SIR YHOMAS MAITLAND; the Mastery of the Mediterranean. BY IVALTER FREIVEN LORD.

3. JOHN CABOT AND HIS SONS; the Discovery of North America. By C. RAYMOND BEAZLEY, M.A.

4 EDWARD OIBBON WAKEFIELD; the Colonisation of South Australia and New Zealand. By R. GARNeTT, C.B., L.L.D.

5. LORD CLIVE; the Foundation of British Rule in India. By Sir A. J. ARBuThNot, K.C.S.I., C.I.E.

RAJAH BROOKE; the Englishman as Ruler of an Eastern State. By Sir SPENSER ST. John, G.C.M.G

ADMIRAL PHILIP; the Founding of New South Wales. By LOUIS BECKE and WALTER JEFFERY.

SIR STAMFORD RAFFLES; England in the Far East. By the Editor. 


\section{THE STICKIT MINISTER AND SOME COMMON MEN \\ $\mathrm{BY}$ \\ S. R. CROCKETT}

Eleventh Edition. Crown 8vo, cloth, 6s.

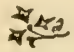

"Here is one of the books which are at present coming singly and at long intervals, like early swallows, to herald, it is to be hoped, a larger flight. When the larger Hight appears, the winter of our discontent will have passed, and we shall be able to boast that the short story can malie a home east as well as west of the Atlantic. There is plenty of human nature-of the Scottish variety, which is a very good variety-in 'The Stickit Minister' and its companion stories; plenty of humour, ton, of that dry, pawky kind which is a monopoly of 'Caledonia, stern and wild'; and, most plentiful of all, a quiet perces tion and reticent rendering of that underlying pathos of life wh ch is to be discovered, not in Scotland alone, but evervwhere that a man is found who can see with the heart and the imagination as well as the brain. Mr Crockett has given us a book that is not merely good, it is what his countrymen would call 'by-ordinar' good,' which, being interpret d into a tongue understanded of the southern herd, means that it is excellent, with a somewhat exceptional kind of excellence."-Daily Chronicle.

\section{THE LILAC SUN- BONNET

Sixth Edition. Crown Swo, cloth, 6s. श्यु

"Mr Crockett's 'Lilac Sun-Bonnet needs no bush,' Here is a pretty love tale, and the landscape and rural descriptions carry the exile back into the Kingclom of Galloway. Here, incleed, is the scent of bog-myrtle and peat. After inquiries among the fair, I learn that of all romances, they best love.

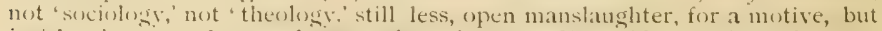
just love's young dream, chapter after chapter. From Mr. Crockett they get what they want, "hot with,' as Thackeray admits that he liked it "

Mr. ANDREw LANG in Longman's Magazine.

11, Paternoster Buildings, London, E.C. 



